\title{
Comparing Three Building Life Cycle Assessment Tools for the Canadian Construction Industry
}

\author{
By \\ Hayley Cormick, Bachelor of Applied Science (BSc.) \\ Queen's University \\ Major Research Project \\ Presented to Ryerson University \\ In part fulfillment of the requirements for the degree of \\ Master of Building Science (MBSc.) \\ in the Building Science Program
}

Toronto, Ontario, Canada, 2017

CCormick, Hayley 


\section{AUTHOR'S DECLARATION FOR ELECTRONIC SUBMISSION OF A MRP}

I hereby declare that I am the sole author of this MRP. This is a true copy of the MRP, including any required final revisions.

I authorize Ryerson University to lend this MRP to other institutions or individuals for the purpose of scholarly research.

I further authorize Ryerson University to reproduce this MRP by photocopying or by other means, in total or in part, at the request of other institutions or individuals for the purpose of scholarly research.

I understand that my MRP may be made electronically available to the public. 


\section{Abstract}

This research aims to contribute to quantifying whole building life cycle assessment using various software tools to determine how they can aid the construction industry in reducing carbon emissions, and in particular embodied emissions, through analysis and reporting. The conducted research seeks to examine and compare three whole building life cycle assessment tools; Athena Impact Estimator, Tally and One-Click LCA to relate the input variability to the outputs of the three programs. The three whole building life-cycle assessments were conducted using a case study building with an identical bill of materials and compared to determine the applicability and strengths of one program over another. The research confirmed that the three programs output significantly different results given the variability in scope, allowable program inputs and generated "black-box" back-end calculations, where the outputted whole building life cycle carbon equivalents of One-Click LCA is less than half than of Tally meaning the programs outputs cannot be simply compared side-by-side. 


\section{Acknowledgments}

I would like to first and foremost thank my MRP advisor Professor Mark Gorgolewski for his guidance over the past year and ongoing support as I navigated my way through this process. He is a model example of putting students first in his practice, and I felt this first hand as his student.

To my second reader Professor Russell Richman, who was so much more than just my second reader over the past year. It was such a pleasure to work with a professor who treats you like a peer. I learned so much from Russell both in and outside the classroom.

To the EllisDon Corporation team, Andrew Bowerbank and Natasha Arsenijevich, who not only had the confidence in me to take on their research, but have introduced me to such a wide network of interesting people, companies and projects along the way. It was a pleasure to work with their team and I look forward to doing it again.

And to the friends I met this past year- I never could have imagined meeting such wonderful people and making such meaningful lifelong friendships. 


\section{Table of Contents}

List of Figures................................................................................................................................................. i

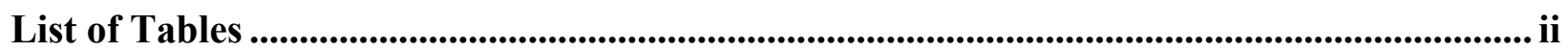

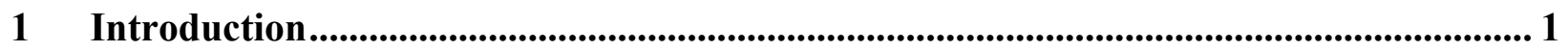

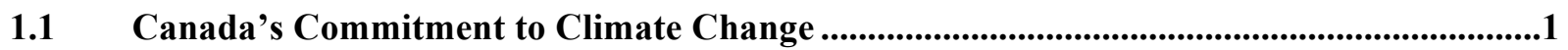

1.2 The Canadian Construction Sector ..........................................................................................2

$1.3 \quad$ Whole Building Life Cycle Assessment .............................................................................................

2 Background ……................................................................................................................ 5

2.1 Quantifying Greenhouse Gas Emissions ....................................................................................

2.2 Greenhouse Gas Emissions Accounting ......................................................................................6

2.3 Carbon Neutrality Definition ....................................................................................................

$2.4 \quad$ Life Cycle Assessment Phases ...............................................................................................

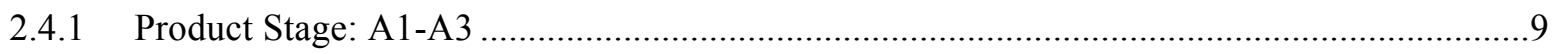

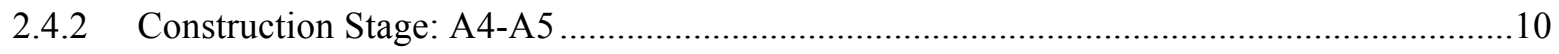

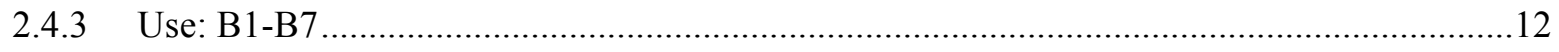

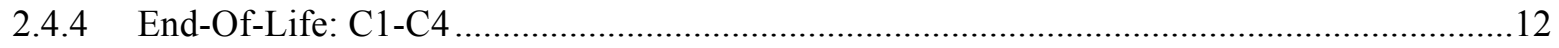

2.5 Life Cycle Emissions Quantification.....................................................................................13

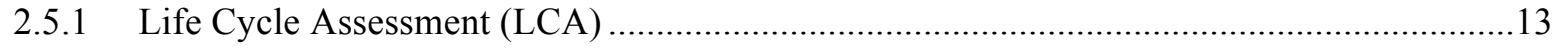

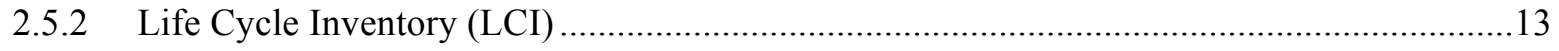

2.5.3 Life Cycle Impact Assessment (LCIA) ………………….............................................13

2.5.4 Environmental Product Declarations (EPDs) ……………………………………….......14

2.6 Life Cycle Assessment Criterion ................................................................................................14

2.7 Existing Life Cycle Assessment Tools......................................................................................15

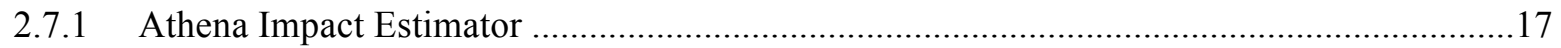

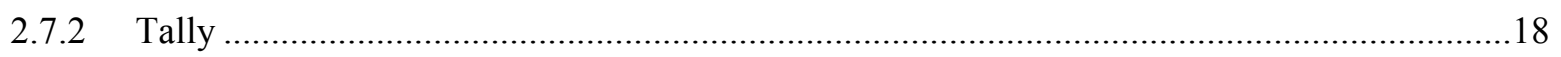

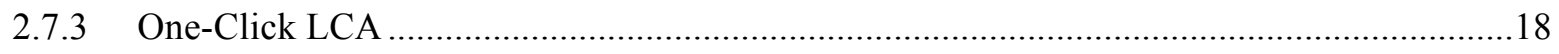

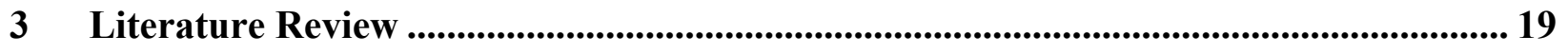

$4 \quad$ Research Objectives................................................................................................................. 23

4.1 Summary of Research Problem ...........................................................................................23

4.2 Research Questions ......................................................................................................................24 
Scope of Work.................................................................................................................................24

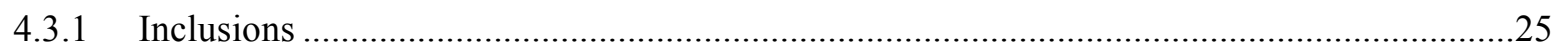

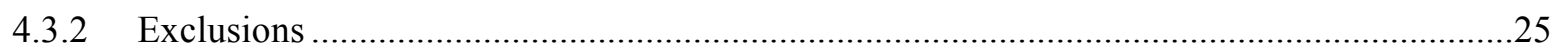

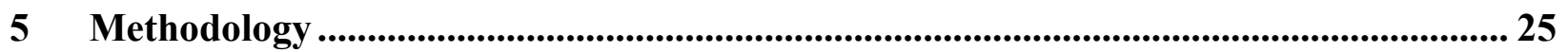

5.1 Life Cycle Assessment Tool Input Capabilities .............................................................................29

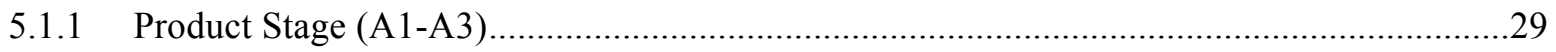

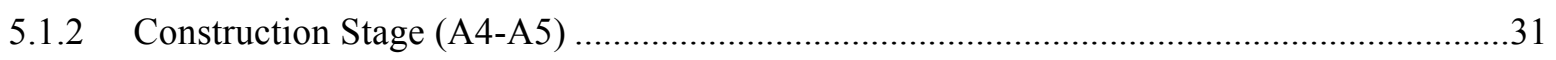

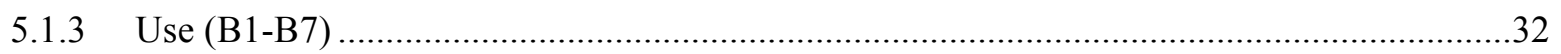

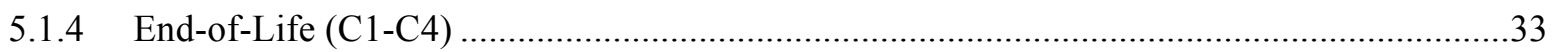

5.2 Case Study: Evergreen Brickworks Kilns..................................................................................33

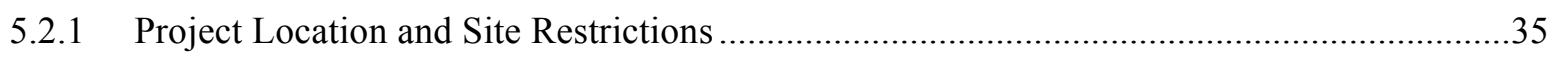

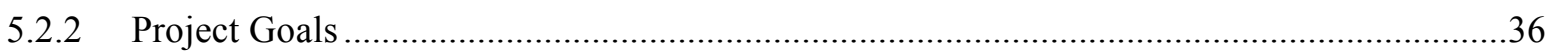

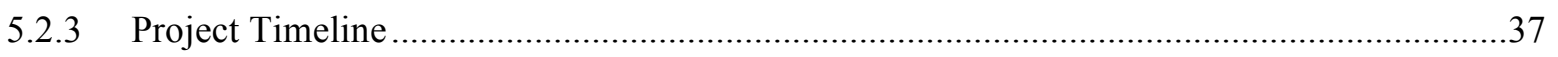

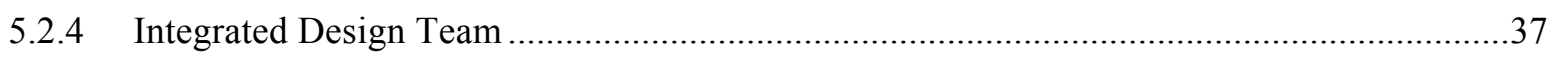

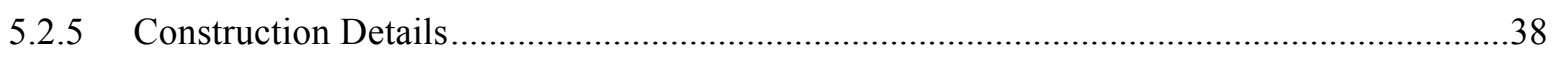

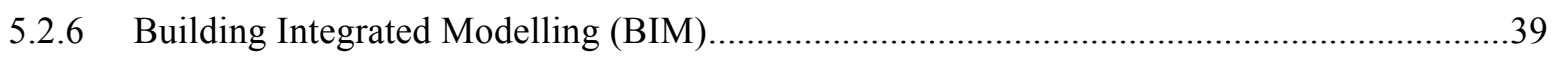

5.2.7 Greenhouse Gas Emissions Sources ............................................................................40

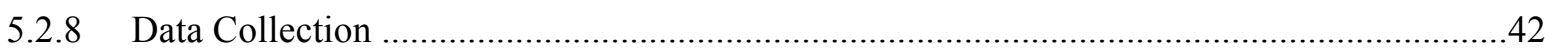

5.3 Case Study Inputs..........................................................................................................................43

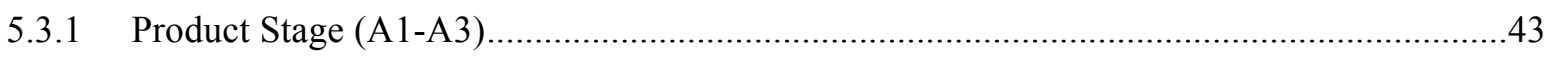

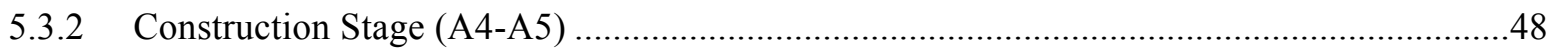

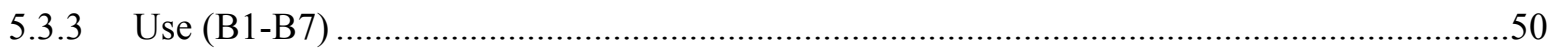

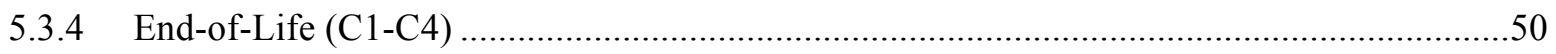

6 Case Study Results .............................................................................................................. 51

6.1 Comparison by Building Element .......................................................................................................51

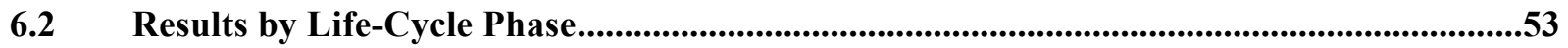

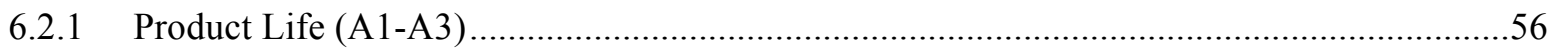

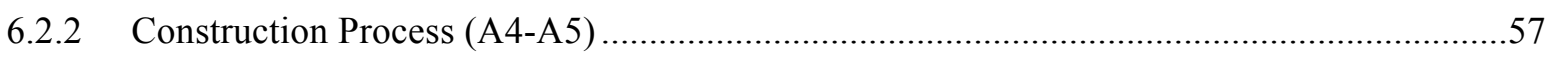

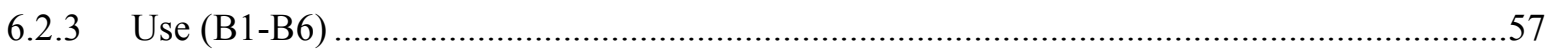

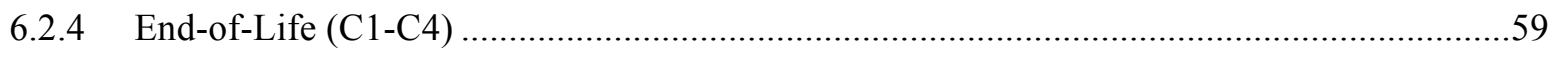

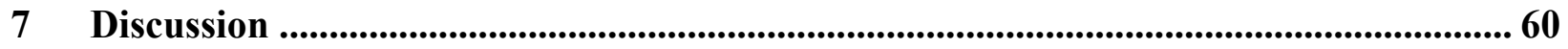

7.1 Regionally Specific Data ...........................................................................................................61

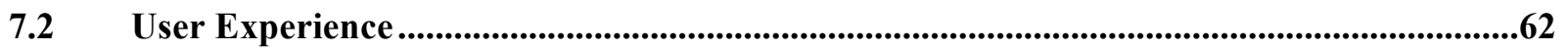




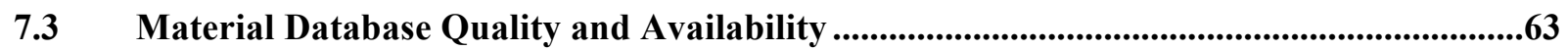

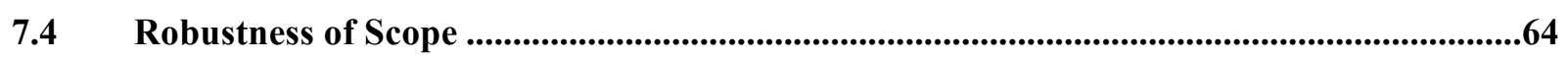

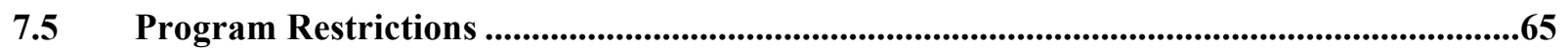

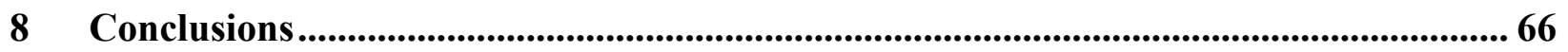

$8.1 \quad$ Future Research ............................................................................................................................69

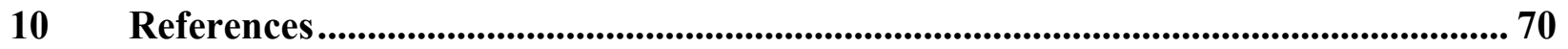

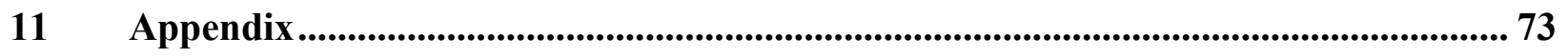




\section{List of Figures}

Figure 1: Life Cycle Assessment Boundary Conditions (Amiri, Caddock, \& Whitehead, 2013).. 6

Figure 2: Cradle-to-Grave Life Cycle Assessment Stages (Johnson, Jowitt, Grenfell, \& Moir, 2012)

Figure 3: A Framework for the Estimation of Carbon Emissions Incurred During the

Construction Phase 11

Figure 4: Life-Cycle Assessment Program-Specific Methodology ............................................ 28

Figure 5: Building 16 Retrofit Overview (ERA Architects Inc., 2016)..................................... 35

Figure 6: Aerial View of the Evergreen Brickworks with Building 16 Highlighted (ERA

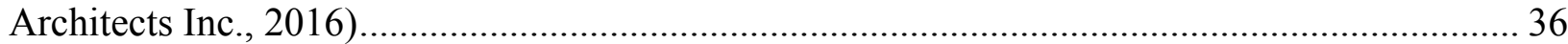

Figure 7: Comparison of the Three Life-Cycle Assessment Tools Total Carbon Dioxide

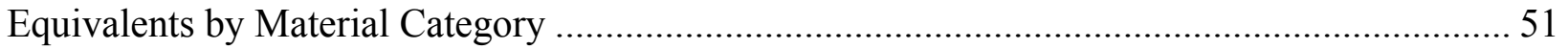

Figure 8: Comparison of the Three Life-Cycle Assessment Tools Total Carbon Dioxide

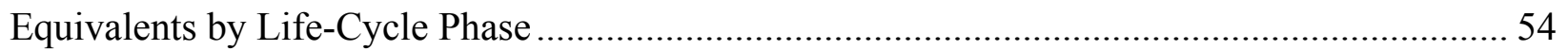

Figure 9: Comparison of the Three Life-Cycle Assessment Tools Total Carbon Dioxide

Equivalents by Life-Cycle Phase (Excluding Operational Energy - B6) ..................................... 55

Figure 10: Comparison of the Three Life-Cycle Assessment Tools Total Primary Energy by Life-

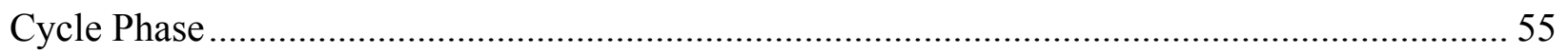

Figure 11: Comparison of the Three Life-Cycle Assessment Tools Total Primary Energy by

Life-Cycle Phase (Excluding Operational Energy - B6) ........................................................... 56

Figure 12: Comparison of Operational Energy (B6) Carbon Dioxide Emissions over the 60-Year

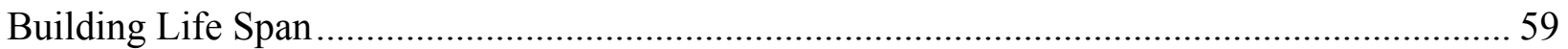




\section{List of Tables}

Table 1: The Scope of Emissions Based on their Direct or Indirect Relation to the Reporting

Organization or Project Owner (Johnson, Jowitt, Grenfell, \& Moir, 2012) ............................... 7

Table 2: Comparison of General Characteristics of Five Leading LCA Tools ......................... 16

Table 3: Summary of Life Cycle Assessment Program Input Capabilities .............................. 29

Table 4: List of Brickworks Kilns Industry Partners and Roles ........................................... 38

Table 5: Bill of Material Quantity Take-Off per the Brickworks Kilns AutoDesk Revit Model. 40

Table 6: Emissions by Project Phase of Evergreen Brickworks Kilns Case Study .................... 41

Table 7: Summary of Project Specified Materials vs. LCA Tool Inputs................................... 44

Table 8: Summary of Life Cycle Assessment Tool Outputs by Phase in ton $\mathrm{CO}_{2} \mathrm{eq}$................. 53

Table 9: Observed Comparison of the Three LCA Tools ..................................................... 61

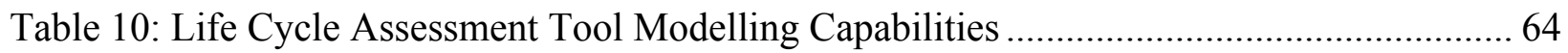




\section{Introduction}

This research aims to contribute to quantifying whole building life cycle assessment using various software tools to determine how they can aid the construction industry in reducing carbon emissions, and in particular embodied emissions, through analysis and reporting. Utilizing appropriate tools and research to make educated material selection choices, change construction processes, reduce travel distances by specifying regional products and manufacturers, and waste processing choices, are becoming more relevant and necessary as governments set legislation to meet carbon reduction targets nation-wide (De Wolf, Pomponi, \& Monc, 2017). The following research study seeks to contribute to how the Canadian construction industry can use life cycle assessment tools to meet sustainability targets and achieve carbon neutrality.

\subsection{Canada's Commitment to Climate Change}

Worldwide, nations are striving to establish new strategies to reduce dependence on fossil fuels and conserve natural resources, particularly following the significant global commitment demonstrated at the 2015 Paris Climate Conference (COP21), where over 190 nations signed a legally binding and universal agreement on climate; the primary outcome being the commitment to keeping global warming below $2^{\circ} \mathrm{C}$, while urging efforts to limit the increase to $1.5^{\circ} \mathrm{C}$ (World Bank Group, 2017). In regard to national application, the conference established binding commitments by all parties to make nationally determined contributions (NDCs), and for all countries to report regularly on their emissions and progress made in implementing and achieving their NDCs, and to undergo international review.

Globally, over 40 national jurisdictions are now implementing some form of carbon pricing to combat climate disruption and manage our natural resources (World Bank Group, 2017). Canada's Federal government has followed suit by committing Canada to reducing total greenhouse gas emissions by 30 percent from the 2005 levels by 2030 (Government of Canada, 2016). The Canadian Government intends to reach these ambitious goals in various ways 
including passing legislation to have a price on carbon. Provincial leaders are also demonstrating leadership toward a low carbon economy by establishing new legislation to curb carbon emissions: Ontario and Quebec have aligned with California to establish a carbon cap and trade system and British Columbia and Alberta has successfully implemented a carbon tax structure; Saskatchewan and Alberta are emerging as global leaders in carbon capture and storage technologies.

Given Canada's highly variable climate, space heating and cooling in buildings contributes greatly in compared to other centralized countries. As well, Canada's sparse population over a large geographical area generally means longer travel times to destinations and high demand on the transportation industry. (Government of Canada, 2017). Despite these challenges, Canada has seen a dissociation between economic growth and GHG emissions, where Canada's share of total global GHG emissions has remained below 2\% over the past two decades (Government of Canada, 2017), attributed to technological improvements, regulation and policy implementation by sector to help reduce emissions. Improved efficiency of equipment and practices as well as consumer understanding and knowledge about environmental choices have greatly influenced Canada's ability to reduce emissions incrementally while managing a growing population and economy.

\subsection{The Canadian Construction Sector}

Employing 7.1\% of all working Canadians and accounting for $6 \%$ of Canada's overall gross domestic product (GDP) contributing \$76.5 billion in 2011, the construction industry plays an important role in Canada's economic stability where the country's infrastructure development has a direct effect on the country's' long term prosperity (Statistics Canada, 2016).

With rapid population growth - 9 billion expected by 2050 worldwide - the demand for large infrastructure projects in both the public and private sectors is not expected to slow. According to the United Nations, the Buildings and Construction sectors account for $40 \%$ of global energy use, $30 \%$ of energy-related GHG emissions, approximately $12 \%$ of water use, nearly $40 \%$ of waste (United Nations Environment, 2016). Buildings and infrastructure provision is directly and 
indirectly related to almost all sectors of the economy based on the materials and energy used in its construction, operation, and resulting built environment (Government of Ontario, 2016).

While recent innovations and regulation have helped to reduce operational energy and carbon impacts, embodied impacts, which include the process of creating the materials and components, have been paid significantly less attention, lacking in comparable methodologies, data and regulation (De Wolf, Pomponi, \& Monc, 2017). Advancement in technology and building material performance have been significantly improved, however by increasing the capabilities of technology and materials, the embodied carbon emissions of the improved systems often substantially increase, creating a shift in high emitting phases from the operating phase to the manufacturing phase (Amiri, Caddock, \& Whitehead, 2013).

Given the ambitious goals set out by provincial and federal governments, the construction industry is under increased pressure to change the way in which infrastructure is constructed in order to meet the demands of the low carbon economy (Government of Ontario, 2016). In Ontario's Climate Change Action Plan (OCCAP), which was released in June of 2016, the former Minister of Environment and Climate Change, Honorable Glen Murray, stated "Our actions will help more Ontario households and businesses adopt low- and net zero carbon energy solutions in homes, vehicles and workplaces. We will [....] halt rising greenhouse gas pollution from buildings by retrofitting existing buildings and ensuring that future buildings have the lowest possible emissions. We will continue to be a strong centre of modern, clean manufacturing and jobs - and a leader in the clean-tech sector. We will become a leading North American hub for low- and net zero-carbon technology companies" (Government of Ontario, 2016).

What this means is that the provincial and national government is committed to transforming the buildings sector. With a growing number of incentives, impending changes in the building code, binding international commitments, and a national price on carbon, there is a growing need to accurately and effectively monitor and document GHG impacts. The Government of Ontario has put forward a call for action to industry to create a universally adaptable carbon accounting tool that can be implemented in all new and existing infrastructure to aid in creating realistic and 
achievable baseline carbon reduction targets and form incentives for future construction. The upcoming January 2018 roll out of the Cap and Trade program in Ontario will put emphasis on the required level of accuracy and inclusions or exclusions from the program, making advancements in carbon accounting in the construction industry critical in parallel with the roll out.

The recent release of the Canadian Green Building Council's Zero Carbon Building Standard is the first of its kind in Canada to require whole building life cycle assessment report (Canadian Green Building Council, 2017). While the program does not specify a carbon savings target like the LEED v4 materials credits, it familiarizes the industry with life cycle assessment tools and their capabilities.

\subsection{Whole Building Life Cycle Assessment}

As cities and communities continued to be built, it is imperative that there is an understanding of the true environmental impact of a building's over its lifecycle. Once the impact is quantified, informed decisions about how to reduce or offset emissions can be implemented. By analyzing and identifying the most harmful building materials and processes, the knowledge to better predict environmental externalities of future construction projects can encourage the adoption of alternative and sustainable clean-tech products and processes (Johnson, Jowitt, Grenfell, \& Moir, 2012).

The purpose of the assessment is to inform design decisions by understanding the environmental impacts over the whole life of a project based on the available data at the time of the decision and a more accurate report at project completion when all design information and project changes have been finalized.

Worldwide, the construction industry is putting increased focus on the importance of whole building life cycle assessment, however given the currently un-regimented boundary conditions and scope, the purpose of the exercise is being lost in the inconsistency of the data outputted. Jowitt, Johnson, Moir and Grenfell of ICE Institute of Civil Engineers Publishing have put 
forward a global protocol for whole building life carbon assessment of infrastructure project that establishes a defined and consistent scope of the greenhouse gases that should be counted and by whom. The purpose of creating a common protocol or framework is to create consistency and transparency among the industry allowing projects to be compared side-by-side, determine accurate benchmarking and be adaptable across different construction sectors.

The protocol is a conglomerate of numerous guidance documents, industry research and current life-cycle assessment tool parameters. The protocol addresses the need for best estimate carbon accounting during the early phases of a project, but should be followed up with accurate and verified inputs upon project completion. This point is integral when analyzing the value of lifecycle assessment tools, as an early stage whole building life-cycle assessment can achieve significantly different results than the as-built condition (Johnson, Jowitt, Grenfell, \& Moir, 2012).

\section{Background}

\subsection{Quantifying Greenhouse Gas Emissions}

Given the unique atmospheric lifetime and heat-trapping potential of each GHG, the Global Warming Potential (GWP) is a unit-less metric that has been developed to compare the heat trapping capacity of a GHG to that of carbon dioxide over an agreed period of time - usually 100 years (Government of Canada, 2017). Carbon dioxide equivalences are determined by multiplying the total mass of a particular GHG released into the atmosphere by the GWP of the GHG and summing the total carbon dioxide equivalences within a defined scope.

$\mathrm{CO}_{2} e q=G W P * G H G$ emission (tonnes)

Equation 1

The six most common greenhouse gases contributing to global warming are referred to as the "Kyoto six pack" including carbon dioxide, methane, nitrous oxide, hydrofluorocarbons, perfluorocarbons and sulfur hexafluoride, which all have differing global warming potentials. In buildings, the most predominant contributor is carbon dioxide released from burning fossil fuels, 
solid waste and wood, as well as the result of certain chemical processes for example in the manufacturing of cement (United States Environmental Protection Agency, 2017).

Emission factors vary significantly by province due to the high variability in population, energy sources and economic sectors. When considering electricity generation provinces that rely heavily on fossil fuels will have higher emissions than provinces relying more on renewable sources (Government of Canada, 2017).

Greenhouse gas (GHG) emissions in Ontario were lower in 2015 than in 1990 by a total of $15 \mathrm{Mt}$ $\mathrm{CO} 2 \mathrm{eq}$ (6\% reduction) largely due to the change from its reliance on the manufacturing industry to the economic centre it is now, and the closure of coal-fired electricity generation plants shifted the provinces electricity production to renewable sources. In 2015, Ontario represented 23\% of the national total greenhouse gas emissions (Government of Canada, 2017).

\subsection{Greenhouse Gas Emissions Accounting}

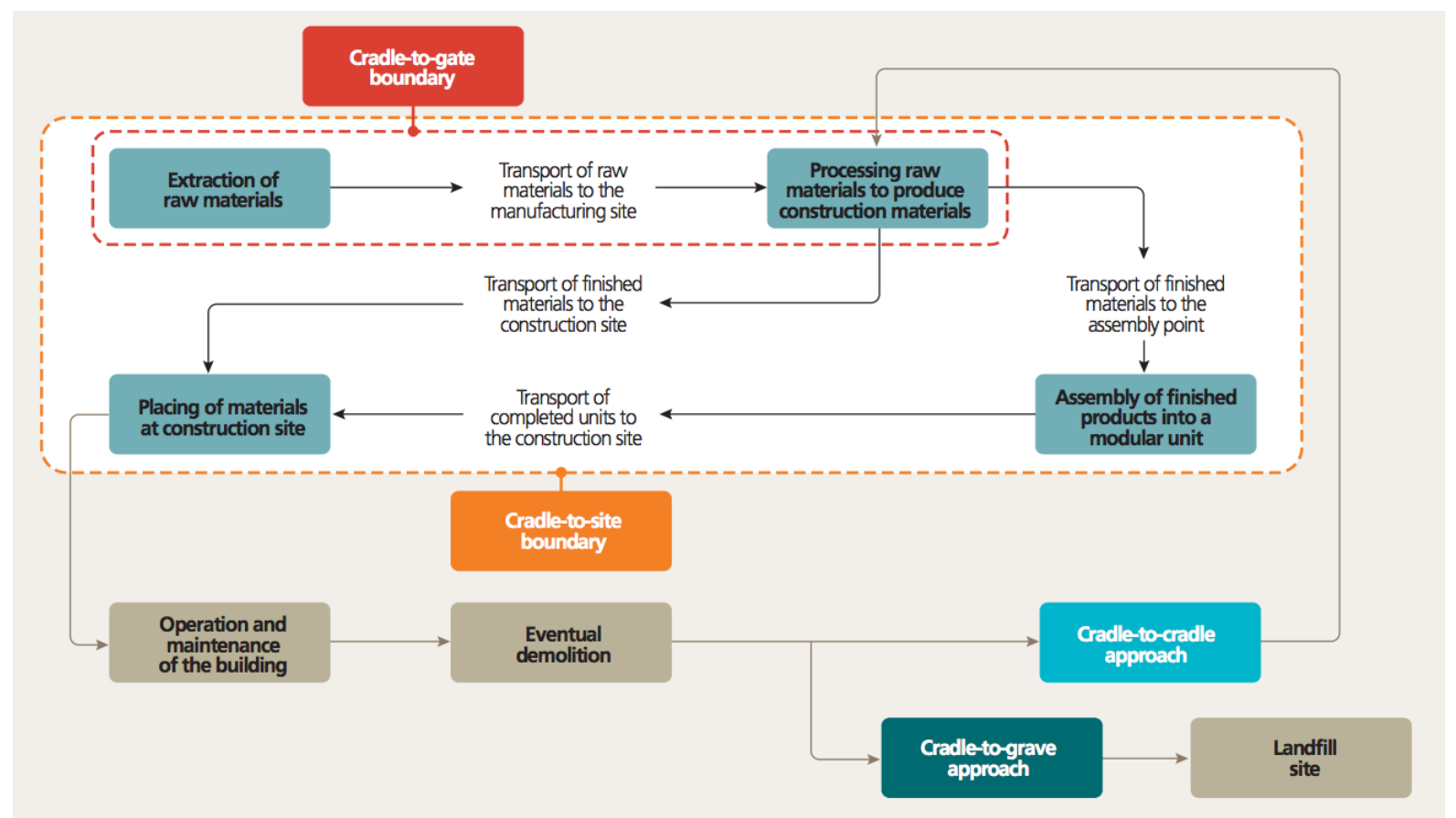

Figure 1: Life Cycle Assessment Boundary Conditions (Amiri, Caddock, \& Whitehead, 2013)

Determining and defining carbon neutrality requires a comprehensive and accurate accounting method that considers all stages of a projects life within a pre-defined scope. As depicted in the 
diagram in Figure 1, the boundary conditions define which project stages are included in the scope. A cradle-to-gate boundary considers all works that take place in the creation of the materials used on site including raw material extraction and material processing and manufacturing, including any transportation between such stages. A cradle-to-site boundary condition further includes material assembly of modular units and placement of materials on the site, including all transportation between stages. A cradle-to-grave boundary further includes the construction processes, operation and maintenance, and demolition and waste over the lifetime of the project. A cradle-to-cradle boundary condition further considers the reuse potential of materials at the project's end-of-life (Amiri, Caddock, \& Whitehead, 2013).

The widely adapted method of identifying emissions into three scopes aid in understanding the roles of emissions ownership responsibility of an organization, building, or project of any type, as summarized in Table 1 (Johnson, Jowitt, Grenfell, \& Moir, 2012). The total emissions accounted in a project is the sum of the three scopes and can be quantified using a cradle-tograve life-cycle assessment tool to determine the total emissions accumulated over the lifespan of the project.

Table 1: The Scope of Emissions Based on their Direct or Indirect Relation to the Reporting Organization or Project Owner (Johnson, Jowitt, Grenfell, \& Moir, 2012)

\begin{tabular}{|l|l|l|}
\hline Scope & Definition & Example \\
\hline Scope 1 & $\begin{array}{l}\text { Direct emissions from activities owned or } \\
\text { controlled by the reporting organization }\end{array}$ & $\begin{array}{l}\text { On-site energy generating processes, on- } \\
\text { site fossil fuel combustion in boilers or } \\
\text { furnaces }\end{array}$ \\
\hline Scope 2 & $\begin{array}{l}\text { Indirect emissions from electricity, heat, steam } \\
\text { and cooling purchased by the reporting } \\
\text { organization }\end{array}$ & $\begin{array}{l}\text { Operational heating and cooling loads, } \\
\text { energy utilized during construction process }\end{array}$ \\
\hline Scope 3 & $\begin{array}{l}\text { Other emissions from sources that are not } \\
\text { owned or controlled by the organization }\end{array}$ & $\begin{array}{l}\text { Waste disposal, embodied emissions of } \\
\text { materials, business travel }\end{array}$ \\
\hline
\end{tabular}




\subsection{Carbon Neutrality Definition}

Carbon neutrality is defined as a balance between the measured amount of equivalent carbon emissions released from the "Kyoto Six-Pack" greenhouse gases with an equal and opposite offset or sequestration to create a net-zero carbon footprint (Carruthers \& Casavant, 2013). The impact each greenhouse gas has on the atmosphere is expressed in terms of carbon dioxide equivalence $\left(\mathrm{CO}_{2} \mathrm{eq}\right)$, allowing the unified unit to be summed and reported as a total carbon dioxide equivalent, simplifying and streamlining the reporting process.

The U.S. Department of Energy's defines a net-zero source energy building as a building which, on a source basis, the annual delivered energy is less than or equal to the on-site renewable exported energy. Source energy is defined as the total site energy plus the energy consumed in the extraction, processing and transport of primary fuels such as coal, oil and natural gas; energy losses in thermal combustion in power generation plants; and energy losses in transmission and distribution to the building site (U.S. Department of Energy, 2015). While an official definition of net-zero carbon buildings is not readily accepted in the same way, carbon neutrality is defined as the sum of all operational carbon and embodied carbon of all life cycle phases, or in other words the sum of Scope 1, 2 and 3 emissions as defined in Table 1.

\subsection{Life Cycle Assessment Phases}

The life cycle of a project can be defined as the chronological stages of a product or service, from raw material extraction to end-of-life decommissioning and final disposal. Life cycle assessment (LCA) is a method used to determine any associated environmental impacts and externalities that can be attributed in the manufacturing and functionality of a product or service (Gan, Cheng, \& Lo, 2016). This systematic approach accounts for all inputs and outputs of energy and greenhouse gas emissions during the entire lifecycle, expressing a total impact that can be stated in total energy or carbon dioxide equivalence. It is critical to identify the source and associated owner of each process, whether upstream or downstream to accurately assign ownership and responsibility at each stage of the assessment. ISO 14040, the international standard on environmental management and life cycle assessment defines the principles and 
framework for life-cycle assessment including the scope and goal of life cycle assessment, and describes the relationship between each life cycle phase.

A building's lifecycle can best be depicted in Figure 2, where a cradle-to-grave full lifecycle assessment considers stages $\mathrm{A} 1$ through to $\mathrm{C} 4$. The internationally recognized annotation system from EN 15978 will be used from here forward in this report when referring to the life cycle stages.

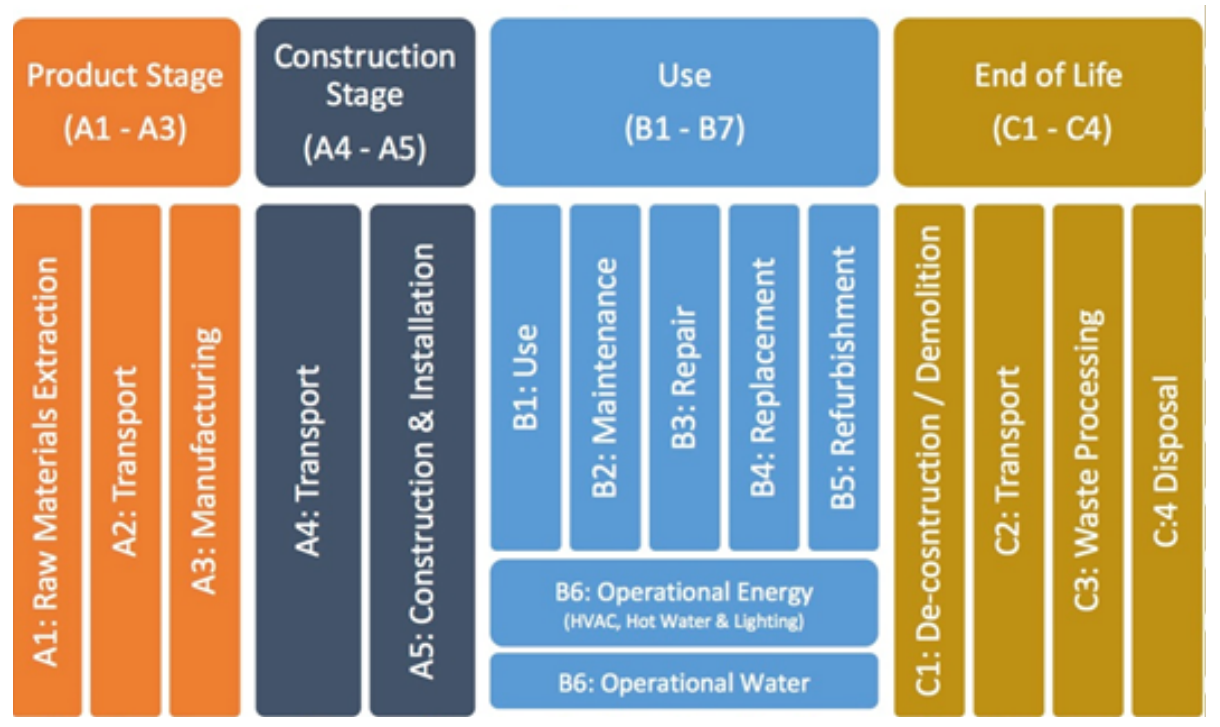

Figure 2: Cradle-to-Grave Life Cycle Assessment Stages (Johnson, Jowitt, Grenfell, \& Moir, 2012)

\subsubsection{Product Stage: A1-A3}

The product stage of life cycle assessment includes the carbon dioxide emitted to extract the raw materials for new material manufacturing, the transportation between the extraction site and the manufacturing site, and the emissions exhausted during the manufacturing process. Life cycle inventories are often of mixed quality, or of generic materials rather than specific products and manufacturers, however as organizations adopt standardized methods and program ambassadors such as LEED enforce third party verified life cycle assessment data, the quality and abundance of material embodied carbon is expected to improve (De Wolf, Pomponi, \& Monc, 2017). 


\subsubsection{Construction Stage: A4-A5}

The construction phase of life cycle assessment includes the emissions associated with the transportation of material to site and the project construction processes. The construction phase is difficult to quantify into a total carbon dioxide equivalence because under current construction practices and regulation, it is not obligatory to meter motorized vehicles to and from site or to sub-meter the construction site to accurately state the associated emissions due to construction (ThinkStep Gabi, 2017).

Construction generally involves a substantial amount of transportation including transport of materials and equipment from the supplier's site to the construction site, transport of materials, equipment and workers around the construction site, and transport of project employees to and from the construction site. The emissions due to transportation vary significantly depending on the site's geographic location, size and complexity, and method of transportation (ThinkStep Gabi, 2017).

Equation 2 is used to quantify the total carbon emissions due to transport of materials, waste and equipment, in tons $\mathrm{CO}_{2}$. Where $\mathrm{EC}_{\mathrm{T}}$ is the total carbon emissions, $\mathrm{Qj}_{\mathrm{j}}{ }^{\mathrm{k}}$ is the amount of building material, waste or equipment in tonnes to be transported by vehicle $\mathrm{k}, \mathrm{T}_{\mathrm{j}}^{\mathrm{k}}$ is the total distance for item $\mathrm{j}$ in vehicle $\mathrm{k}$ in kilometers, and $f_{\mathrm{k}}{ }^{\mathrm{T}}$ is the emissions factor for transportation using vehicle $\mathrm{k}$ in kilograms of $\mathrm{CO}_{2}$ eq per tonnes kilometer (ThinkStep Gabi, 2017).

$E C_{T}=\sum_{j} \sum_{k} Q_{j}^{k} x\left(T_{j}^{K} x \int_{k}^{T}\right) / 1000 \quad$ Equation 2

The carbon emissions associated with on-site construction processes are difficult to accurately estimate in advance of the completion of the project or activity as the need for availability for actual site data such as the amount of electricity, fuel, water and various other materials used by different trades is required and often not monitored. On-site construction carbon emissions vary substantially depending on the type and energy efficiency of equipment used, amount of material, characteristics of the building project and construction site restrictions (Xiao, 2017). 
Figure 3 summarizes the emission sources relevant to the construction phase that should be considered in the total carbon emissions in phase A5. The schematic includes temporary materials used such as concrete forms and considers their reuse potential and life span before requiring replacement (Xiao, 2017).

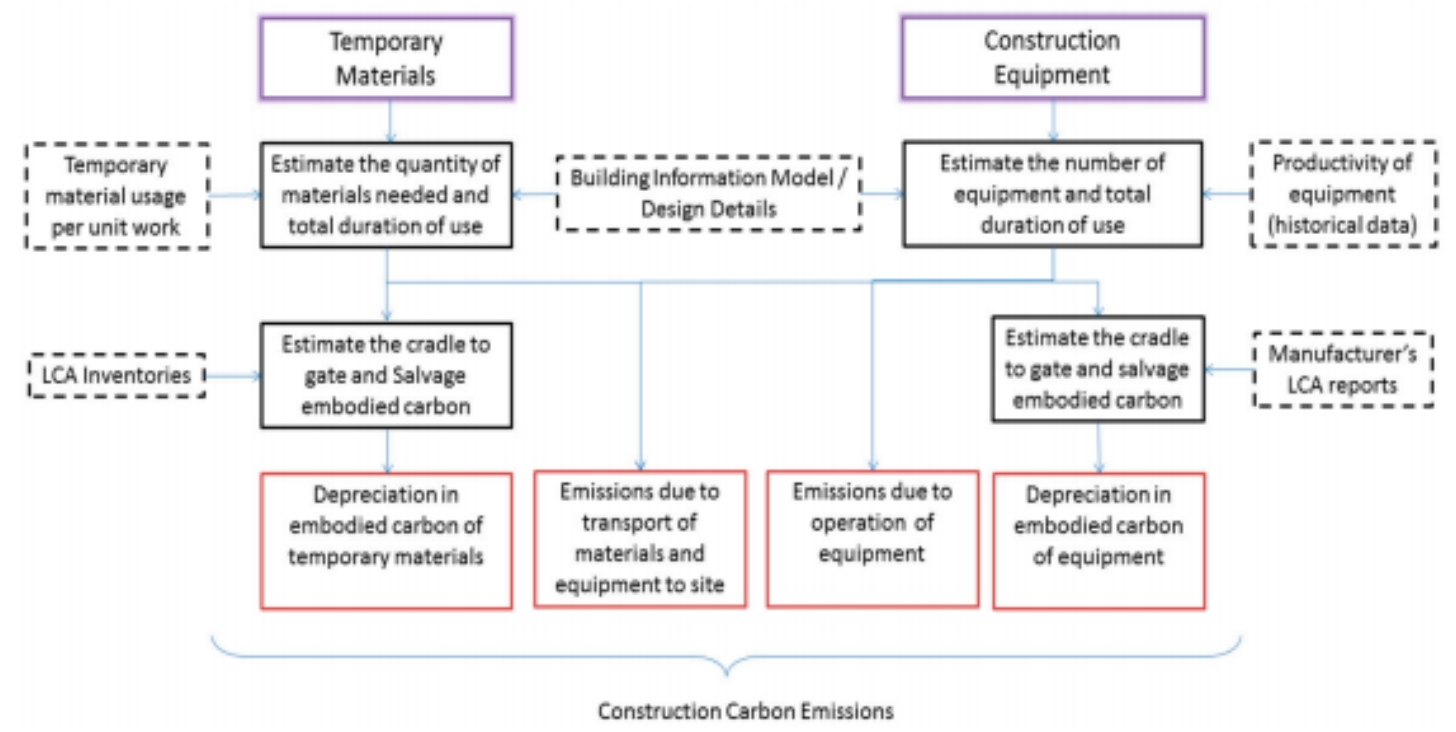

Figure 3: A Framework for the Estimation of Carbon Emissions Incurred During the Construction Phase

Equation 3 depicts the total emissions incurred due to the operation of equipment during on-site construction. $\mathrm{E}$ is the total emissions incurred in $\mathrm{CO}_{2} \mathrm{eq}, \mathrm{EP}$ is the available engine power of the equipment in horsepower, OT is the duration of operation, ER is the emissions factor for the specific equipment and fuel type used and LF is the load factor, referring to the average fraction of the engine that is actually used including idling and partially loaded equipment (ThinkStep Gabi, 2017).

$E=E P x O T \times E R \times L F$ Equation 3

The construction phase poses high uncertainty and site-specific conditions that cannot simply be assumed by project typology or site location. Specifically, during the demolition process, it is often unknown to what extent the site requires grading, trenching or excavation prior to the commencement of works. Additional uncertainty can arise based on the project size, equipment type and reuse potential of material or site works from previous site work (Xiao, 2017). 


\subsubsection{Use: B1-B7}

The operations phase of life cycle assessment includes the emissions associated with the building during its period in use. These emissions include the electricity, water and fuel required to operate the conditioning system, lighting and equipment and the emissions associated with maintenance, repair, replacement and refurbishment of the building. Operational energy and water use is readily understood and attainable data given energy modelling software's and post occupancy sub-metering (Xiao, 2017). Material maintenance, repair, replacement and refurbishment can be estimated based on a typical lifespan of a particular product, however is variable depending on the climate, exposure to human contact, mould, rot and other contributors. Mechanical and electrical equipment have a typical lifespan, however when worked over capacity, in extreme weather or improperly commissioned, the lifespan can be variable.

\subsubsection{End-Of-Life: C1-C4}

The end-of-life phase of life cycle assessment includes the emissions associated with the deconstruction and demolition process, transportation to local waste facilities, waste processing and disposal. The end-of-life strategy is highly dependent on the building parameters such at the type of materials used, the original design and connections of building components, availability of technologies to optimize reuse and recycling, availability of landfills for sorting and disposal (Xiao, 2017).

Estimating the carbon emissions associated with a building's end-of-life poses challenges given that the estimation is often done on average 50 years prior to the time at which the emissions will be emitted, as the assessment is completed at the start of the project. Projected improvements to technologies, landfills site locations, transportation routes and material reuse and recycling potential is estimated at the time of construction based on current predictions, meaning results are reported with a high level of uncertainty.

Where available, Environmental Product Declarations (EPDs) are used to estimate the end-of-life emissions of each material, based on third-party assessments conducted on present-day projects documented emissions at the end-of-life stage (Xiao, 2017). 
This report focuses principally on the product and construction stages of the building life to better understand their impacts and how they can be analyzed.

\subsection{Life Cycle Emissions Quantification}

Life cycle assessment (LCA) is the overarching term that quantifies the environmental impact of a material or product over its life time. LCA are informed by a thorough life cycle inventory (LCI) of all the processes undertaken to manufacture the material or product, which are then multiplied by the associated emissions factor to convert flow quantities into environmental impact quantities through life cycle impact assessment (LCIA). Environmental Product Declarations (EPDs) are third-party verified LCAs of a particular product or material manufacturer.

\subsubsection{Life Cycle Assessment (LCA)}

Life cycle assessment is conducted on a product or service to determine its environmental impact over its lifetime. The multi-step procedure compiles and examines the inputs and outputs of materials and energy and their associated environmental impacts directly attributed to by the product or service (Athena Sustainable Materials Institute, 2011).

\subsubsection{Life Cycle Inventory (LCI)}

Life cycle inventory is the quantification of input and output flow of materials, energy or raw resources throughout the lifetime of a specified product or service (Athena Sustainable Materials Institute, 2011).

\subsubsection{Life Cycle Impact Assessment (LCIA)}

Life cycle impact assessment converts each LCI process into the environmental impacts associated with the particular process. The sum of the environmental impacts from all processes in the LCI is the basis of a product's LCA (Athena Sustainable Materials Institute, 2011). 


\subsubsection{Environmental Product Declarations (EPDs)}

When available, emissions inventories such as Environmental Product Declarations (EPDs) can be used as the basis for estimating cradle-to-gate embodied carbon and other emissions. EPDs use the reporting format outlined by the ISO 14025 standard, providing a standardized set of information categories for reporting LCA results and allow side-by-side product comparisons of products of similar typology. EPDs are performed by certified third party assessment company and distinguish the embodied carbon of a particular product based on its composition, extraction and manufacturing locations, core upstream and downstream processes and use of resources (Hardy \& Owens, 2013).

Requirement of EPDs on construction sites is yet to be widely adapted where product databases are not specific to a particular manufacturer, but rather a generic product. It should be noted that the embodied carbon of materials can vary significantly by the manufacturing processes used, depending on technologies used and the properties of the raw material. As well, the transport requirements may vary considerably from one manufacturer to another depending on the location of the processing sites, location of material quarries and suppliers, and layout of the facilities, leading to different transport-related carbon emissions for different manufacturers (Xiao, 2017).

\subsection{Life Cycle Assessment Criterion}

Life cycle assessment requires a standardized framework to ensure transparency and consistency among projects of similar typology. The intention is to provide guidance to all applicable stakeholders including policy makers, consultants, designers, contractors and operating organizations. The framework should consider the following in order to ensure a well-rounded and thorough assessment (Johnson, Jowitt, Grenfell, \& Moir, 2012).

- Be applicable to all building typologies and set consistent boundaries according to the specific greenhouse gases contributors across projects of a similar type.

- Build on already established greenhouse gas emissions and life cycle analysis assessment approaches. 
- Be applicable to all stages of project development including design, construction and feasibility, operation, in-use and decommissioning.

- Compare alternative material and process options in terms of whole life carbon emissions.

- Take account of upstream and downstream emissions of the project.

- Use regionally appropriate emission factors and update periodically as a result of changes in the fossil/ non-fossil mix of energy supply and changes in efficiency in relation to material processing, equipment manufacturer and operational activities.

- Record the source and date the emission factors, along with the range of uncertainty.

- Include non-costed aspects that further influence the total life cycle emissions such as land-use costs and change of land allocation.

- Determine a common unit of reporting of carbon intensity such as $\mathrm{CO}_{2}$ eq per area or per user, to enable comparison between projects and establish baselines by project typology.

- Recognize estimations and assumptions when made.

By understanding and recognizing the need for a standardized framework for carbon accounting in the construction industry, life cycle assessment tools are used to quantify and validate the total life-cycle carbon accumulated over the lifetime of a project be it a building, infrastructure or civil project. Currently available life cycle assessment tools are not regulated or required to address all items in the above assessment criterion, meaning the tools output differing results given the assumptions and inputs available.

\subsection{Existing Life Cycle Assessment Tools}

Table 2 summarizes the capabilities of five readily available life-cycle assessment tools and their general characteristics that set them apart from one another. Information presented in the table is primarily gathered from the program website, with the exception of Tally, Athena Impact Estimator and One-Click LCA where communications with the company confirmed information.

Although ThinkStep GaBi and SimaPro have been used for whole building assessments, they are not designed specifically for that purpose. They are primarily used in product based life cycle 
assessment and life cycle inventory creation and are therefore less relevant to whole building life cycle assessment.

Table 2: Comparison of General Characteristics of Five Leading LCA Tools

\begin{tabular}{|c|c|c|c|c|c|}
\hline & $\begin{array}{l}\text { Athena } \\
\text { Impact } \\
\text { Estimator }\end{array}$ & Tally & $\begin{array}{l}\text { One Click } \\
\text { LCA }\end{array}$ & $\begin{array}{l}\text { ThinkStep } \\
\text { GaBi }\end{array}$ & SimaPro \\
\hline $\begin{array}{l}\text { Company } \\
\text { Ownership }\end{array}$ & $\begin{array}{l}\text { Athena } \\
\text { Sustainable } \\
\text { Material } \\
\text { Institute }\end{array}$ & $\begin{array}{l}\text { KT } \\
\text { Innovations, } \\
\text { ThinkStep, } \\
\text { AutoDesk }\end{array}$ & BioNova Ltd. & ThinkStep & $\begin{array}{l}\mathrm{PRe} \\
\text { Consultants }\end{array}$ \\
\hline $\begin{array}{l}\text { Life Cycle } \\
\text { Capabilities }\end{array}$ & $\begin{array}{l}\text { Whole- } \\
\text { Building }\end{array}$ & $\begin{array}{l}\text { Whole- } \\
\text { Building }\end{array}$ & $\begin{array}{l}\text { Whole- } \\
\text { Building }\end{array}$ & $\begin{array}{l}\text { Product Based } \\
\text { - Not Building } \\
\text { Specific }\end{array}$ & $\begin{array}{l}\text { Product Based - } \\
\text { Not Building } \\
\text { Specific }\end{array}$ \\
\hline $\begin{array}{l}\text { Material Data } \\
\text { Collection Source }\end{array}$ & $\begin{array}{l}\text { Athena LCI } \\
\text { Database }\end{array}$ & $\begin{array}{l}\text { GaBi LCI, } \\
\text { NREL LCA, } \\
\text { Quartz Project, } \\
\text { ASTM }\end{array}$ & $\begin{array}{l}\text { All Verified } \\
\text { EPD's }\end{array}$ & $\begin{array}{l}\text { GaBi } \\
\text { Database }\end{array}$ & $\begin{array}{l}\text { EcoInvent, } \\
\text { USLCI, ELCD }\end{array}$ \\
\hline $\begin{array}{l}\text { Program } \\
\text { Integration }\end{array}$ & $\begin{array}{l}\text { Stand Alone } \\
\text { Program }\end{array}$ & $\begin{array}{l}\text { AutoDesk } \\
\text { Revit } \\
\text { Integrated }\end{array}$ & $\begin{array}{l}\text { BIM } \\
\text { Integrated/ } \\
\text { Online Access }\end{array}$ & $\begin{array}{l}\text { Stand Alone } \\
\text { Program }\end{array}$ & $\begin{array}{l}\text { Stand Alone } \\
\text { Program }\end{array}$ \\
\hline $\begin{array}{l}\text { Software Update } \\
\text { Frequency }\end{array}$ & Bi-Annual & Periodically & $\begin{array}{l}\text { On request } \\
\text { within } 24 \\
\text { hours }\end{array}$ & Annually & Periodically \\
\hline $\begin{array}{l}\text { Iso } 14040 \& \\
14044 \text { Compliant }\end{array}$ & Yes & Yes & Yes & Yes & Yes \\
\hline $\begin{array}{l}\text { System } \\
\text { Boundaries }\end{array}$ & $\begin{array}{l}\text { Cradle-to- } \\
\text { Grave }\end{array}$ & $\begin{array}{l}\text { Cradle-to- } \\
\text { Grave }\end{array}$ & $\begin{array}{l}\text { Cradle-to- } \\
\text { Grave }\end{array}$ & $\begin{array}{l}\text { Cradle-To- } \\
\text { Grave }\end{array}$ & $\begin{array}{l}\text { Cradle-To- } \\
\text { Grave }\end{array}$ \\
\hline Country of Origin & Canada & USA & Finland & Germany & Netherlands \\
\hline $\begin{array}{l}\text { Geographic } \\
\text { Variability }\end{array}$ & $\begin{array}{l}\text { North America } \\
\text { Only }\end{array}$ & Yes- US Only & Yes & Yes & European Based \\
\hline $\begin{array}{l}\text { Canadian } \\
\text { Applicability }\end{array}$ & Yes & $\begin{array}{l}\text { Weak } \\
\text { Canadian } \\
\text { Material } \\
\text { Database }\end{array}$ & Yes & Yes & Yes \\
\hline Models M\&E & No & No & Yes & No & No \\
\hline Leed V4 Verified & Yes & Yes & Yes & Yes & Yes \\
\hline $\begin{array}{l}\text { Material Lifespan } \\
\text { Modifications }\end{array}$ & $\begin{array}{l}\text { Embedded in } \\
\text { Program }\end{array}$ & $\begin{array}{l}\text { Embedded in } \\
\text { Program }\end{array}$ & $\begin{array}{l}\text { Auto- } \\
\text { Populates, can } \\
\text { be modified }\end{array}$ & Yes & Yes \\
\hline
\end{tabular}




\begin{tabular}{|c|c|c|c|c|c|}
\hline $\begin{array}{l}\text { End-of-Life } \\
\text { Outputs }\end{array}$ & $\begin{array}{l}\text { Deconstruction } \\
\mathrm{n} \text {, demolition, } \\
\text { disposal, waste } \\
\text { processing \& } \\
\text { transport }\end{array}$ & $\begin{array}{l}\text { Does not } \\
\text { include } \\
\text { transportation }\end{array}$ & $\begin{array}{l}\text { Deconstruction } \\
\text { and waste }\end{array}$ & Unknown & Unknown \\
\hline $\begin{array}{l}\text { Mode of } \\
\text { Transportation } \\
\text { and distance }\end{array}$ & $\begin{array}{l}\text { Auto- } \\
\text { populated to } \\
\text { nearest NA } \\
\text { city }\end{array}$ & $\begin{array}{l}\text { Auto- } \\
\text { Populates, can } \\
\text { be modified } \\
\text { (mode and } \\
\text { distance) }\end{array}$ & $\begin{array}{l}\text { Auto- } \\
\text { Populates, can } \\
\text { be modified } \\
\text { (mode and } \\
\text { distance) }\end{array}$ & Yes & Yes \\
\hline $\begin{array}{l}\text { Operational \& } \\
\text { Construction } \\
\text { Waste }\end{array}$ & $\begin{array}{l}\text { Waste factor } \\
\text { included in } \\
\text { material } \\
\text { quantities }\end{array}$ & No & No & Yes & Yes \\
\hline $\begin{array}{l}\text { Skill Level } \\
\text { Requirement }\end{array}$ & Moderate & $\begin{array}{l}\text { High Revit } \\
\text { Skill Required }\end{array}$ & Moderate & Advanced & Advanced \\
\hline Transparency & $\begin{array}{l}\text { Undisclosed } \\
\text { "back-end } \\
\text { calculations" }\end{array}$ & $\begin{array}{l}\text { Outputs } \\
\text { project specific } \\
\text { report with } \\
\text { detailed } \\
\text { information. } \\
\text { Some } \\
\text { undisclosed } \\
\text { "back-end" } \\
\text { calculations }\end{array}$ & $\begin{array}{l}\text { Undisclosed } \\
\text { "back-end } \\
\text { calculations" }\end{array}$ & $\begin{array}{l}\text { High } \\
\text { transparency } \\
\text { of "back-end" } \\
\text { calculations }\end{array}$ & $\begin{array}{l}\text { High } \\
\text { transparency of } \\
\text { "back-end" } \\
\text { calculations }\end{array}$ \\
\hline
\end{tabular}

\subsubsection{Athena Impact Estimator}

The Athena Impact Estimator for Buildings is a whole-building life-cycle assessment tool that reports footprint data for the following impact categories: acidification, global warming potential, human health risk, respiratory effect potential, ozone depletion, smog potential, eutrophication and total fossil energy. The program pulls LCA and LCI data from the Athena Database and other North American databases. Electricity gird mixes, transportation modes and distances, and product manufacturing technologies are all regionally specific to the geographical location of the project.

Athena Impact Estimator operates by either inputting a project's bill of materials or by building the project in the program itself, the latter of which calculates the bill of materials within the 
program. Athena Impact Estimator is not a user intensive program as outputs are primarily dictated by back end research and averages, rather than site/project specific data.

\subsubsection{Tally}

Tally, developed by KieranTimberlake in the United States and released in 2013, is a building integrated modelling (BIM) plug-in that determines quantity take-offs directly from AutoDesk Revit. Tally is a whole building life cycle assessment tool that gathers materials information from the GaBi LCI database, and all data is from the U.S., with the intention to develop worldwide in the future. Tally allows user input specific to the project for transportation distances from product manufacturer to site, annual operational energy, and construction process energy and water. Tally reports the following impact categories: acidification, eutrophication, global warming potential, ozone depletion potential, smog formation and primary energy demand.

\subsubsection{One-Click LCA}

One-Click LCA, developed by BioNova Limited in Finland is a web-based program that gathers a project bill of materials from any BIM program, including but not limited to AutoDesk Revit. The One-Click LCA material database accepts any EPD worldwide, so long as it is third-party verified, meaning the database includes only specific materials and products by specific manufacturers, not generic materials. The One-Click LCA team inputs new EPDs within 24 hours of their confirmation of verification.

Unique to One-Click $L C A$, the program is compliant with over 50 rating systems, assessment measures and standards worldwide, meaning the program has numerous impact categories available for assessment and comparison, depending on the needs of the user. 


\section{Literature Review}

Life cycle assessment is conducted in research and literature extensively using either hand calculations or assessment tools in three primary ways: to report total greenhouse gas emissions in a particular case study building, to quantify the percent carbon savings from building retrofits over new builds, and to compare materials or methods to determine the difference in life cycle carbon emissions. Little research has been done in comparing assessment tools and the variability in outputs, creating the basis for the research conducted.

Life cycle assessment tools are readily used in research to report and analyze the effects a project has on the environment over its life span. One study, conducted by Kylili et al. published in Resources, Conservation and Recycling publication, analyzed a passive house certified building within the sub-tropical climatic zone, using EcoHestia assessment tool to optimize the benefits of lowering operational energy over the life time of the building by adding material and in hand, increasing embodied energy. The parametric analysis conducted concluded that the significant operational energy savings from thick mineral wool envelope assemblies effected the total embodied carbon of the building in a minor way in proportion to the percent savings in operational energy over the life time of the building (Kylili, Ilic, \& Fokaides, 2017).

Paleari et al. conducted a study on a net-zero site energy residential building in Italy to underline the difference between and energy only approach to energy efficiency and an environmental approach considering a building's life cycle. In the particular case study, $54 \%$ of the total impacts are from the product stage and the use phase accounts for $41 \%$. The research proved that as buildings are becoming more efficient and using significantly less operational energy over its life time, embodied energy plays a greater role. (Paleari, Lavagna, \& Campioli, 2016)

Another typical use for whole building life cycle assessment in research is to compare a baseline building and an improved or upgraded building to demonstrate the percent embodied energy or carbon savings the projected is projected to save in compared to a typical new build. The Athena Sustainable Materials Institute has completed a number of studies like this, such as the UBC 
Biological Sciences Complex Renew project, which proved that the building avoided the consumption of 4 million liters of water, 24,000 gigajoules of fossil fuels, and 13,000 tonnes of materials by renovating rather than demolishing and building new (Athena Sustainable Materials Institute, 2011). Similarly, research was conducted using Tally by Overland Architects in San Antonio, Texas on the Hughes Warehouse that determined that the adaptive reuse project reduced the total embodied energy on the adaptive reuse building by $48 \%$ in compared to a new build (The American Institute of Architects, 2017).

A study conducted at RMIT University in Melbourne, Australia presents an integrated life cycle framework that parametrically optimized eight heritage retrofit buildings to both minimize embodied and operational energy. The research was conducted using SimaPro for the embodied energy assessment and AccuRate for the operational energy simulation. Being designated heritage buildings, certain restrictions were placed on the allowable new construction. Each building was analyzed in its existing condition and then in various configurations by adding insulation, high performance windows and sealants to determine which had the greatest impact on reducing operational energy without significantly impacting embodied energy (Pow Chew Wong \& Iyer-Raniga, 2011).

Life cycle assessment is commonly used to quantify and compare the environmental impacts associated with alternative building designs and material selection. One study, conducted by the University of British Columbia, compared the cradle-to-gate environmental impacts of a typical cast-in-place reinforced concrete frame to a laminated timber hybrid design. Results from the mid-ride office case study building indicated that the laminated timber hybrid design scored lower in 10 of 11 assessment categories including embodied carbon (Robertson, Lam, \& Cole, 2012).

Another relevant study was conducted that looks further into the embodied energy and carbon of glazing systems- particularly of interest for this study as minimal glazing and curtain wall systems - product specific or generic - are included in life cycle assessment tool databases. The study compares the impacts of a transparent composite façade system to a glass curtain wall system. The study was performed at the University of North Carolina and concluded that the 
glass curtain wall system had $89 \%$ higher total emissions that then transparent composite façade system. The use phase in both systems proved to be dominant, given the short life span of glazing systems requiring repair, replacement, refurbishment and maintenance over the life time of the building (Kim, 2011).

The Oak Ridge National Laboratory conducted a study comparing four insulation materials which achieve the same thermal resistance value to determine the difference in primary energy consumption and global warming potential. SimaPro LCA software was used to compare polyisocyanurate (PIR) foam insulation, expanded (EPS) and extruded (XPS) polystyrene foam insulation and aerogel where results showed that XPS has the greatest embodied carbon and aerogel has the greatest embodied energy using the same functional unit across all analysis (Biswas, Shrestha, Bhandari, \& Desjarlais, 2015).

There are a limited number of published studies comparing different whole building life cycle assessment tools and the implications the differences in tools have on reported results. Herrmann et al. conducted a comparison of SimaPro and GaBi ThinkStep, two life-cycle assessment tools for products and systems, to determine whether results yield identical, similar or different outputs given the same product and inputs. The study concluded that the programs yield differences so large that they could influence the reported assessment (Herrmann \& Moltesen, 2014). This study is however less relevant to whole building life cycle assessment as it is in reference to specific materials and system flows, but demonstrates the importance of consistency among programs to better ensure reporting accuracy.

Another study, conducted by Haapio et al. from the Helsinki University of Technology in Finland compared 16 different European and North American based life cycle assessment tools to analyze and characterize the existing tools into groups based on their common features and purpose (Haapio \& Viitaniemi, 2008). Tools are categorized in two ways; The Athena Classification System and the IEA Annex 31 Classification System. The Athena Classification System categorizes tools into three levels: level 1 are product comparison tools and information sources, level 2 are whole building design and decision support tools, and level 3 are whole building assessment frameworks or systems. The IEA Annex 31 Classification System 
categorizes tools into a directory of 5 categories; (1) energy modelling software, (2) environmental LCA tools for buildings and building stock, (3) environmental assessment framework and rating systems, (4) environmental guidelines or checklists for design and management of buildings and (5) environmental product declarations, catalogues, reference information, certifications and labels. Tools within the same level can be compared side-by-side. The Athena Impact Estimator is classified as a level 2 in both the Athena Classification System and IEA Annex 31 classification system. The Athena Impact Estimator is compared against 7 other tools based on its capabilities, for example whether it can model existing buildings, new building refurbishments, and what building typologies can be modelled. The study also shows which life cycle phases each tool can model and the source of the material databases (Haapio \& Viitaniemi, 2008). The purpose of the study is to highlight the variability in tool functionality and ability to help users select the most appropriate LCA tool when conducting analysis.

Al-Ghamdi et al. of The University of Pittsburgh conducted a whole building life cycle assessment tool comparison of SimaPro and Athena Impact Estimator that aimed to identify the significant differences between the tools based on user experience, transparency of results and assumptions, geographical area, building system modelling and program integration. The research found there is a tradeoff between simplicity and transparency, where the Athena Impact Estimator can be conducted by a wider range of practitioners and consultant's due to its straight forward inputs, SimaPro provides more detailed results and explanations of assumptions and back-end operations (Al-Ghamdi \& Bilec, 2017). The study found a difference in reporting results greater than $10 \%$ based on a case study building located in Pittsburgh, Pennsylvania. The conclusion of the research paper identifies the need to refine life-cycle assessment methods and to obtain more robust data sets. The need for future research is pivotal to overcome the challenges in data quality and uncertainty (Al-Ghamdi \& Bilec, 2017).

Extensive research has been conducted by the Athena Sustainable Materials Institute on life cycle assessment reporting of materials, products, systems and whole buildings, where very little research has been conducted on Tally and One-Click LCA as the programs are young and therefore new to both research and industry. Given the literature reviewed for the creation of this research paper, a lack in understanding of the major differences and discrepancies between the 
three selected whole building life cycle assessment tools has been identified. In order to ensure quality and comparable reporting between programs, a better understanding of the differences in programs in required, creating the need for the research presented here. The research will seek to determine whether the research done to date by Al-Ghamdi et al. is in agreeance or contradictory to that completed here with different life cycle assessment tools.

\section{Research Objectives}

\subsection{Summary of Research Problem}

Following the release of the Ontario Climate Change Action Plan in June 2016, the Ontario Government has put out a call for action to the construction sector to create a consistent, accurate and readily available carbon accounting tool that is applicable to all new and existing building and infrastructure projects in Ontario. In response to the call for action, EllisDon Corporation, a Canadian general contractor, has requested an in-depth research study on the existing life cycle assessment tools on the market and available in Canada to determine their applicability to the call for action. EllisDon Corporation's end goal is to create a tool that provides real-time carbon accounting information on all active and completed projects in both the public and private sector in order to be able to report the company's total carbon emissions on all projects at any time. This research aims to contribute to the current understanding of carbon accounting and educate the construction industry on the selection of one tool over another when conducting whole building life cycle assessments, or provide recommendations for the creation of a new tool should the current programs not provide sufficient tracking for their purposes.

This research seeks to investigate the current and fast-changing discussion around carbon accounting and how life-cycle assessment tools are used to quantify and report the environmental impacts of buildings by evaluating the strengths and weaknesses of the three most commonly used tools in North America. The purpose of conducting the three life cycle assessment models is to understand the extent to which the user has control over the inputs and to identify the most significant discrepancies between models. 
While there are numerous whole building life cycle assessment tools worldwide, the three selected have been identified by the newly released Canadian Green Building Council's Zero Carbon Building Framework, and therefore are likely to see an influx of users in the Canadian context upon the release of the framework in September 2017.

\subsection{Research Questions}

This research aims to address the following research questions:

1. What are the major similarities and differences between three readily available life-cycle assessment tools for Canadian construction projects?

1a. How much input flexibility is inherent in three readily available life-cycle assessment tools and identify the effect in output variability and accuracy?

1b. Which programs or strategies offer the most effective carbon accounting mechanism for the Canadian construction market?

\subsection{Scope of Work}

This research project seeks to examine and compare three life cycle assessment tools; Athena Impact Estimator, Tally and One-Click LCA. The scope of work includes a review of the inputs and outputs of the three programs to understand the applicability and strengths of one program over another. The three programs conduct full life-cycle assessments from project design to endof-life, meaning the boundary conditions of each program remains identical, however each program permits different inputs and performs different "back-end" calculation methods impacting output consistency.

In order to perform a comparison between programs, a case study was performed where the Evergreen Brickworks Kilns Building 16 was modelled in the three programs and results outputted for comparison. The same geographical boundary conditions were used on the three 
models as well as the same bill of materials, in order to allow side-by-side result comparisons. A 60 -year building lifespan was used for the three models.

\subsubsection{Inclusions}

The three life cycle assessment models included all new envelope materials, curtain wall, floors, roof, windows and doors. Material quantities were determined using the AutoDesk Revit file bill of materials and materials selected to closest match to the Brickworks Kilns specification document. The life cycle assessment is conducted using the Phase 2 construction documents issued July 27, 2017 (Revision 8).

\subsubsection{Exclusions}

The three life cycle assessment models excluded all existing materials/components of the building, as the project only considers new construction in the embodied carbon quantification. In order to create a side-by-side comparison of the tools, an identical bill of materials is used across all three programs. Given the program restrictions and available databases, mechanical and electrical equipment, plumbing, conduit, landscaping, furniture, appliances, connection details and sealants are not included in the three models. As well, given that the Brickworks Kilns project is an adaptive reuse project, limited structural changes were made, having minimal impact to the overall outputs, therefore structural members are excluded. The life cycle assessment does not include the Phase 3 because at the time of this report creation in August 2017, works were in the design stage and documents not finalized.

\section{Methodology}

Three whole building life-cycle assessment tools were analyzed and compared based on their differences in program input, back-end calculations and assumptions, and reported outputs. A thorough literature review and involvement on the Evergreen Brickworks Kiln design team showed insight into the largely undefined method of accounting for carbon and the need for a universally adopted framework that is applicable to all building and infrastructure projects in Canada. 
Below is the method followed to answer the research questions presented:

1. Meet with EllisDon Corporation to discuss their needs for a carbon accounting tool and determine the purpose, long term vision and steps taking to-date on pilot projects to account for carbon

2. Attend Evergreen Brickworks Kilns project design team bi-weekly meetings and progress site team meeting

a. Determine project timelines including phasing and funding limitations

b. Determine the project scope of work

c. Obtain floor plans, elevations, specifications and information regarding the history of the building, specifically repairs and renovations from the building owner and design team

d. Understand design team's vision and goals for the project

3. Define scope of carbon neutrality in relation to the Brickworks Kilns project and method intended to achieve it

a. Define Scope 1,2 and 3 emissions and life cycle phase emissions specific to the Brickworks Kilns project

b. Determine inclusions and exclusions from the carbon neutrality scope and reasoning for each decision

4. Review literature to determine how life cycle assessment tools have been used in research to date and their applicability and similarities to the Brickworks Kilns project

5. Research readily available whole building life cycle assessment tools available in Canada and determine three leading tools for comparison

6. Review literature on comparing life cycle assessment tools and whether Tally, One-Click LCA and Athena Impact Estimator have previously been compared to each other or other tools

7. Define research questions

a. Define scope of research

b. Determine inclusions and exclusions from scope 
c. Determine Brickworks Kilns project construction drawing set to be used in research (Phase 2)

8. Obtain preliminary Building Information Modelling (BIM) AutoDesk Revit file from internal design team

a. Cross reference AutoDesk Revit file with floor plans, elevations and specifications and update file where needed to reflect Phase 2 works

9. Model three life cycle assessment tools in parallel. Individual program specific methodologies are mapped in Figure 4

10. Export outputs and results from the three life cycle assessment tools

11. Compare results by life-cycle phase and building component

12. Perform sensitivity analysis to justify program differences and discrepancies

13. Draw case study conclusions

14. Draw general conclusions with regards to program input variability, applicability to the Canadian construction industry and, similarities between programs 


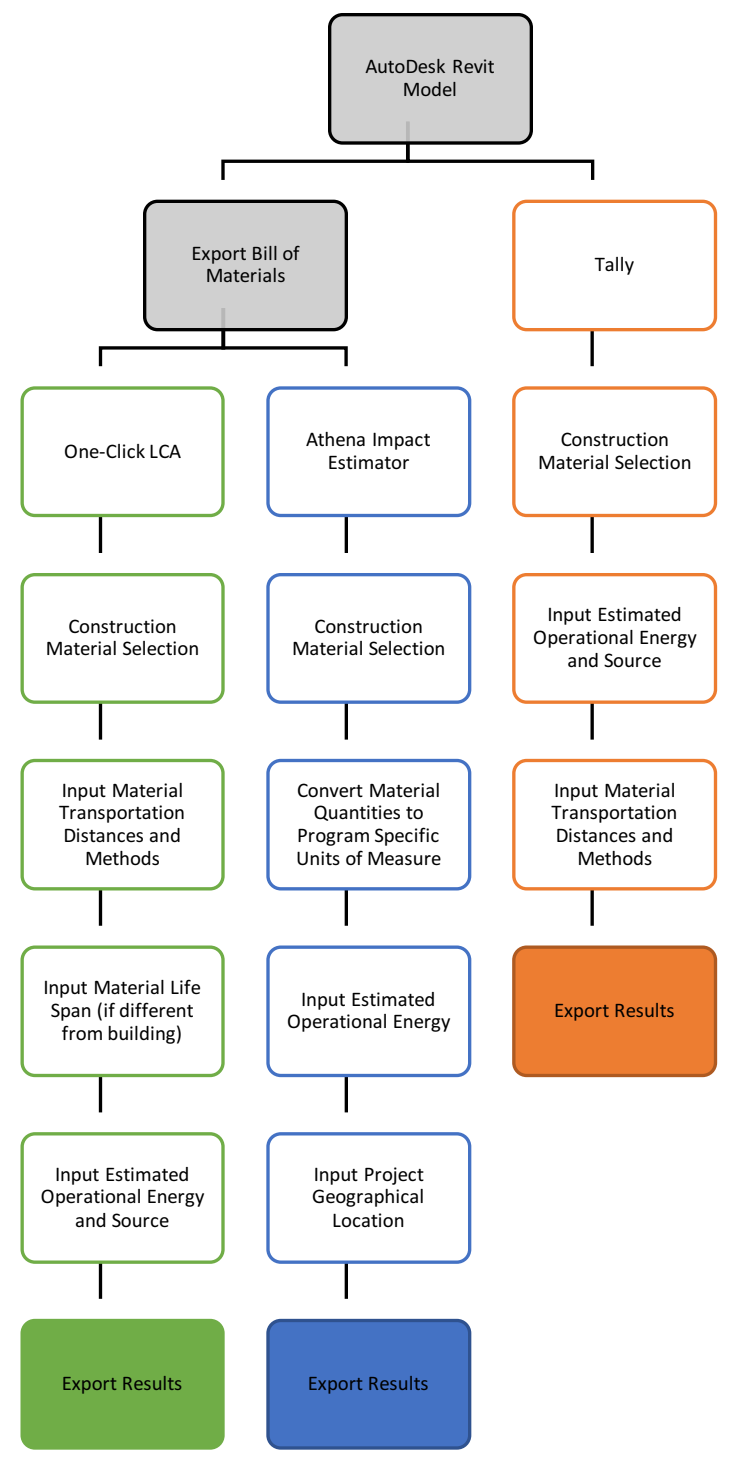

Figure 4: Life-Cycle Assessment Program-Specific Methodology 


\subsection{Life Cycle Assessment Tool Input Capabilities}

Table 3: Summary of Life Cycle Assessment Program Input Capabilities

\begin{tabular}{|c|c|c|c|}
\hline & Tally & Athena IE & $\begin{array}{l}\text { One-Click } \\
\text { LCA }\end{array}$ \\
\hline \multicolumn{4}{|l|}{ Product Stage (A1-A3) } \\
\hline Material Take-Off Method & $\begin{array}{l}\text { AutoDesk } \\
\text { Revit }\end{array}$ & $\begin{array}{l}\text { BOM (excel or } \\
\text { other) or built- } \\
\text { in program }\end{array}$ & $\begin{array}{l}\text { BOM (excel or } \\
\text { other) or } \\
\text { AutoDesk } \\
\text { Revit }\end{array}$ \\
\hline Material Database & $\begin{array}{l}\text { GaBi LCA } \\
\text { Database }\end{array}$ & $\begin{array}{l}\text { Athena } \\
\text { Sustainable } \\
\text { Materials } \\
\text { Institute LCA }\end{array}$ & $\begin{array}{l}\text { All Third-Party } \\
\text { Verified EPDs }\end{array}$ \\
\hline Assembled Material Selection & Yes & No & Yes \\
\hline Material Add-Ons & Yes & No & No \\
\hline Specific or Generic Materials & $\begin{array}{l}\text { Generic (some } \\
\text { specific EPDs) }\end{array}$ & Generic & $\begin{array}{l}\text { Specific EPDs } \\
\text { (generic } \\
\text { Canadian } \\
\text { concrete) }\end{array}$ \\
\hline \multicolumn{4}{|l|}{ Construction Stage (A4-A5) } \\
\hline Transportation Distance Modification & Yes & No & Yes \\
\hline Transportation Method Modification & 4 options & No & $30+$ options \\
\hline Construction Emissions Calculation & $\begin{array}{l}\text { Requires } \\
\text { manual input }\end{array}$ & $\begin{array}{l}\text { Auto } \\
\text { Generated }\end{array}$ & $\begin{array}{l}\text { Auto } \\
\text { Generated }\end{array}$ \\
\hline \multicolumn{4}{|l|}{ Use (B1-B6) } \\
\hline Operational Energy Input & Yes & Yes & Yes \\
\hline Operational Energy Regional Source & Canada Wide & $\begin{array}{l}\text { Closest } \\
\text { Canadian City }\end{array}$ & Provincial \\
\hline Material Life Span Modification & No & No & Yes \\
\hline \multicolumn{4}{|l|}{ End-of-Life (C1-C4) } \\
\hline No end-of-life inputs & & & \\
\hline
\end{tabular}

\subsubsection{Product Stage (A1-A3)}

\subsubsection{Tally}

Tally extracts the material quantities of a project directly from an AutoDesk Revit file where the material take-offs do not require user computation. Tally models a high level of detail in a simplified manner, where features can be selected based on the material purpose. For example, when gypsum wall board is selected, Tally prompts for a finish to be selected, or not. Similarly, 
foil facing can be selected, or not. Stud shapes, spacing, material type and insulation type can all be selected in a single layer. The model allows you to build up wall assemblies in detail and the program auto-generates material quantities.

The Tally material database is generated by the GaBi LCA database and includes primarily generic materials with the exception of some specific manufacturer's EPDs.

\subsubsection{Athena Impact Estimator}

The Athena Impact Estimator has two possible methods to determine material quantities- one from importing an excel spreadsheet bill of materials, and two by building up the model in the program by building component. Method one inputs units of measure specific to the program, requiring unit conversion from the bill of material format to the Athena Impact Estimator specific format. Method one is more practical when an AutoDesk Revit file or thorough bill of materials is provided to the designer. Method two, while simpler to quantify materials including framing spacing and number of doors, requires additional modelling and a thorough understanding of the construction documents in order to build up the model in the program. Method two is more practical when an AutoDesk Revit file or thorough bill of materials is not provided to the designer. The research presented here is conducted using method one.

The Athena Impact Estimator material database is populated using Athena Sustainable Materials Institute LCA database and is made up of generic North American materials.

\subsubsection{One-Click LCA}

One-Click LCA auto-populates the construction material take-offs either from the AutoDesk Revit file plug in or as an excel format bill of materials. In most cases, the material units of measure can either be selected by mass or volume. Should the program not recognize the material name or properties from the import, the program prompts for materials to be selected.

The One-Click LCA material database is populated using all third party verified EPDs worldwide. The program does not include generic materials, with the exception of Canadian 
concrete which is conducted using Canadian Ready Made Concrete Association (CRMCA) mix designs.

\subsubsection{Construction Stage (A4-A5)}

\subsubsection{Tally}

The four transportation methods supported by Tally; truck, rail, barge and shipping container and distances can be modified from the default values for each material specified. The number of vehicles, amount of fuel and travel time are estimated based on the volume or weight of materials.

Tally calculates project construction impacts in a similar manner to operational energy where total electricity, heating and water usage are inputted and the energy source selected. This method poses issues as construction impacts cannot be simply calculated and inputted as it is highly dependent on the building typology, materials specified and project complexity.

\subsubsection{Athena Impact Estimator}

Athena Impact Estimator does not allow user inputs for transportation distances or method of transportation. Athena Impact Estimator estimates transportation of material to site using regional data and the Athena Transport Database (Athena Sustainable Materials Institute, 2011).

Similarly, Athena Impact Estimator does not allow user inputs for construction impacts. Athena Impact Estimator estimates construction impacts using the Athena Construction Energy Database (Athena Sustainable Materials Institute, 2011).

\subsubsection{One-Click LCA}

One-Click LCA allows detailed inputs for calculating the emissions associated with transporting material to site, where the distance and method of transport for each material can be specified. A drop down of over 30 choices including delivery method (van, truck, mixer, plane, train, ship), vessel capacity and percent fill rate can all be selected in order to ensure the most accurate 
emissions factor can be applied. The number of vehicles, amount of fuel and travel time are estimated based on the volume or weight of materials.

One-Click LCA calculated the construction emissions based on material selection and quantities. The method in which values are determined is undisclosed.

\subsubsection{Use (B1-B7)}

\subsubsection{Tally}

The inclusion of operational energy inputs in Tally are optional, and should they be included, must be calculated using an external energy modelling program or other estimation method. The annual heating and electricity summing to the total annual site energy can be inputted into Tally and the energy source selected. Tally's energy source selections are country-wide for all countries outside the United States, meaning specific grid mixes by geographical location are not recognized. Geographical limitations are discussed below.

Material life spans effecting the maintenance, repair, replacement and refurbishment of the building are integrated into the program and cannot be adjusted.

\subsubsection{Athena Impact Estimator}

Athena Impact Estimator allows for an optional input of the building's operating energy consumption of electricity, natural gas, LPG, heavy fuel, diesel and gasoline. The annual operational energy must be calculated in an external program and inputted into the Athena Impact Estimator as a single input. The energy source is based off the geographical location selected, where all major Canadian cities are listed.

Material life spans effecting the maintenance, repair, replacement and refurbishment of the building are integrated into the program and cannot be adjusted. 


\subsubsection{One-Click LCA}

Depending on the license and purpose of analysis, One-Click LCA has operational energy inputs for consumption of grid electricity, fuel demands of stationary units such as generators, consumption of district heating and cooling, and exported energy such as on-site generation. The emissions factor applied to the grid electricity is specific to the geographical location. One-Click $L C A$ specifies the grid mix by Canadian province.

The material life span of each individual material can be modified or changed from the program auto-populated values to reflect the true life span of materials based on climate, exposure, using and other factors. Typically, One-Click LCA auto-populates envelope and structural materials to match the life span of the building, assuming that components cannot be simply replaced or changed individually, and interior and exterior finishes, doors and windows have shorted life spans around 20-30 years versus the building lifespan of 60 years.

\subsubsection{End-of-Life (C1-C4)}

None of the three programs allow input variability that effects the end-of-life carbon impacts in whole building life cycle assessment. Recycling and waste facility selection, waste sorting methods and reuse potential of materials is not specified. In the case of all three programs, the end-of-life scenario is calculated based on the material LCA and EPD inputs, however the method and inputs are undisclosed.

\subsection{Case Study: Evergreen Brickworks Kilns}

Established in 1991, Evergreen is a not-for-profit organization committed to transforming public landscapes into thriving community spaces with environmental, social and economic benefits (ERA Architects Inc., 2016). Their flagship property, the Evergreen Brickworks, is a Toronto landmark located on the historic Don Valley brickworks site, which shut down in 1984. The site contains 16 heritage buildings which have overtime been converted into various public and private spaces serving as exceptional adaptive reuse examples. 
Evergreen's latest project is the transformation of Building 16, the expansive 53,000 square foot kilns facility originally built between 1956-57 for the firing and drying of bricks. The one-storey "Building 16" has the largest building foot print of all the buildings on the site. The building is undergoing extensive renovations to be converted into an all-season, multi-purpose event space. The all-electric building design is expected to use $1,010,000 \mathrm{kWh}$ of electricity annually, according to Brookfield Global Integrated Solutions, the building mechanical engineer. Figure 5 is a schematic of the overall building renovation plan. The extent of work on the project include:

- introduction of radiant floor heating and a new concrete floor

- construction of a new elevated classroom and viewing deck raised above the existing ring kilns

- removal of a portion of drying kilns' walls to create an interpretive gallery

- introduction of doors and glazing along the west elevation of Building 16

- introduction of new catering prep area

- construction of two new entrances integrated into the existing building

- construction of new washrooms integrated into the existing building (ERA Architects Inc., 2016) 

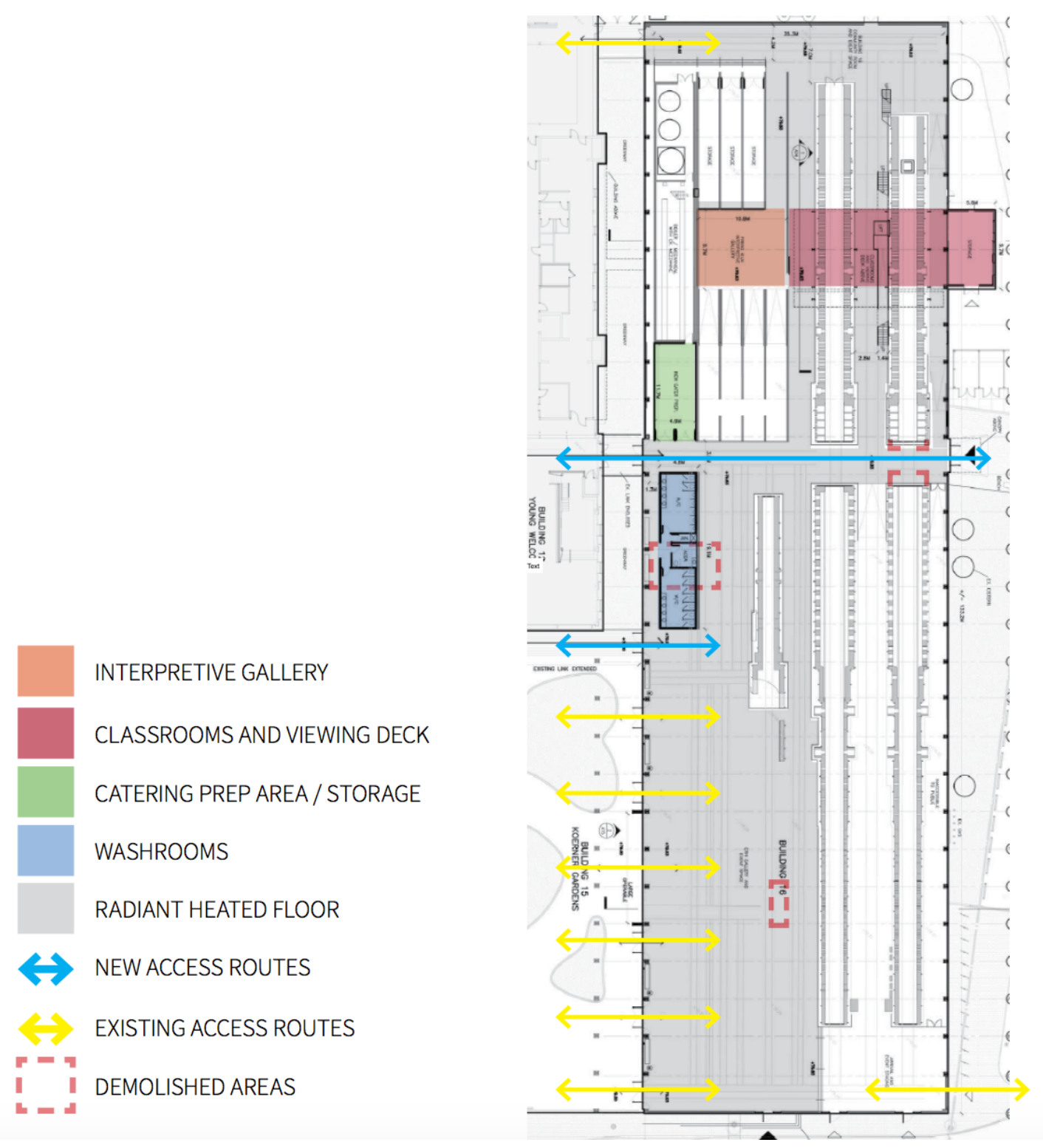

Figure 5: Building 16 Retrofit Overview (ERA Architects Inc., 2016)

\subsubsection{Project Location and Site Restrictions}

The Evergreen Brickworks is located at 550 Bayview Avenue on the West side of the Don Valley River in Toronto, Canada. Building 16 is located on the South-East end of the property, as highlighted in Figure 6.

The retrofit of the kiln building requires adherences to the Ontario Heritage Act (by-law 9862002), as Building 16 was deemed an official heritage site based on its rich historical significance to the City of Toronto. In addition to its heritage status, this project presents special 
circumstances based on its setting. Located near Mud Creek and the Don River, the property sits on a flood plain and is prone to annual flooding over 3 feet, which requires a comprehensive storm water management plan (ERA Architects Inc., 2016).

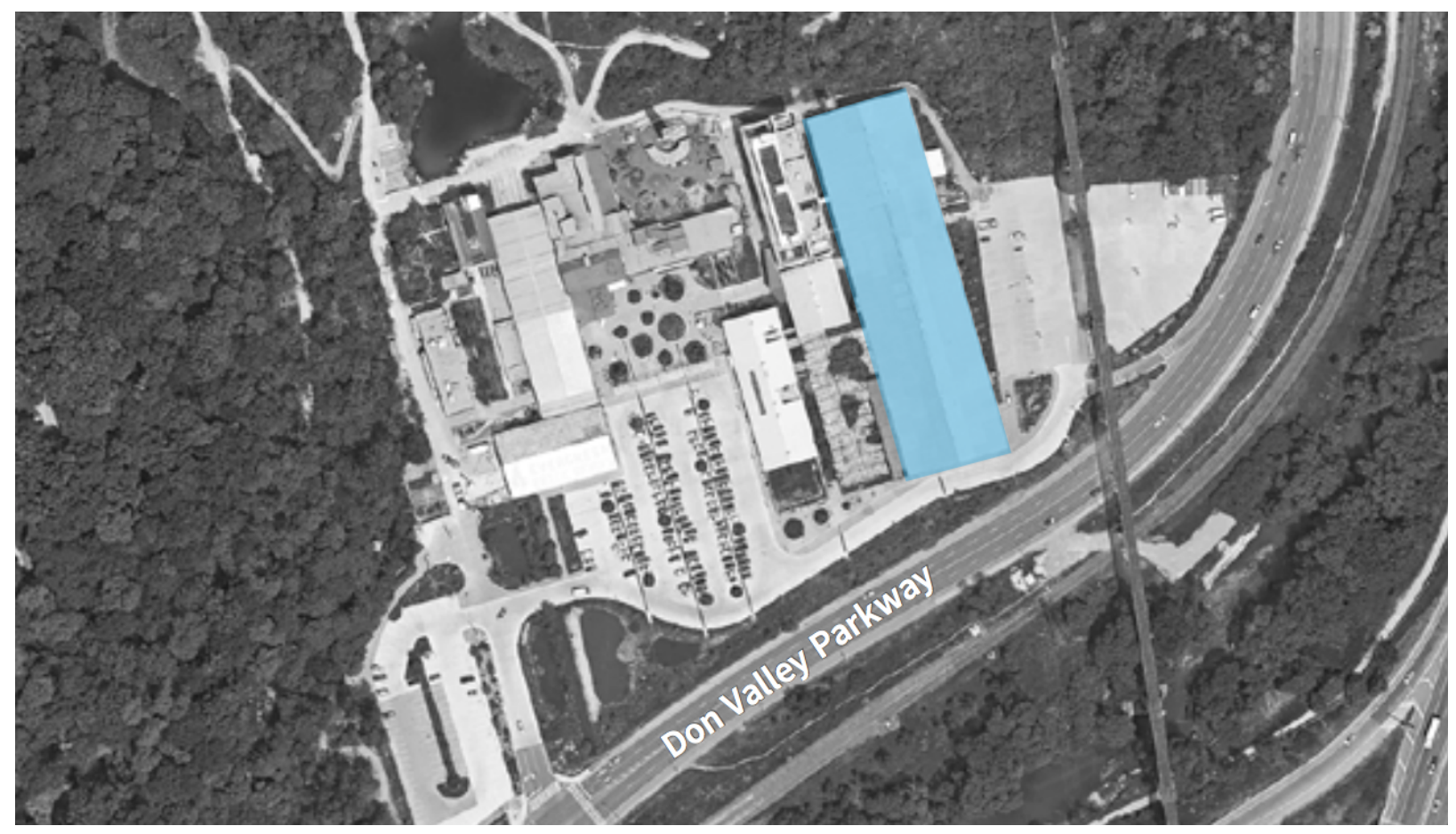

Figure 6: Aerial View of the Evergreen Brickworks with Building 16 Highlighted (ERA Architects Inc., 2016)

\subsubsection{Project Goals}

The overarching goal of Building 16 is to create a "dynamic, year-round super hub that will ignite, accelerate and celebrate new innovations that shape our cities for the better" (Evergreen, 2017). The building integrates new building technologies into an existing heritage building, creating an exemplary adaptive reuse project demonstrating the value of heritage preservation and existing building reuse.

Unique to this building and the first in Canada, the Brickworks kilns project is targeting carbon neutrality. Selected as the first pilot project under EllisDon Corporation's Carbon Impact Initiative, the design team is committed to making the design choices necessary to drive down carbon dioxide emissions and offset the remaining carbon using various innovative offset or sequestration strategies. The definition of carbon neutral adhered to for this project is defined in Section 2.3 of this report, considering all life cycle phases from A1 to C4. 


\subsubsection{Project Timeline}

Because of the fast-paced nature of the project which relies heavily on public and private funding and grants, the project is divided into three phases, where each phase is issued for tender as separate contracts. The design, permitting, pricing and construction of each phase is completed in sequence, but all three phases are at different stages at any one time.

As of August 2017, when this report was created, Phase 1 was complete, Phase 2 was under construction and Phase 3 was in the design and permitting phase. Phase 1 encompasses the removal of specified brickwork, removal of abandoned services, removal of existing electrical equipment, patching of existing brickworks, cleaning of debris, rubbish and demolished features, installation of the raised concrete floor with radiant in floor installed and installation of new structural members on the existing structure. Phase 2 encompasses the enclosure of the building including roof assembly installation, curtain wall installation, service room extension, window and door installation, internal partition wall installation, and washroom and catering kitchen appliance installation. Because the final design documents of Phase 3 have not been released, the research presented in this paper includes only the information from Phases 1 and 2. See Appendix for detailed construction drawings of Phases 1 and 2.

\subsubsection{Integrated Design Team}

The Evergreen team sought out a collaborative design team willing to work together at every stage of the project to achieve the difficult design goals and to design and build a project worth celebrating for its success as an industry leader. A bi-weekly design team meeting held by Evergreen ensures timely and up-do-date information sharing and helps mitigate problems from arising prior, during and post construction.

In order to achieve carbon neutrality, full design team participation is required as the life cycle assessment strategy requires input from all sectors of the project. This can pose problems when design changes occur, material substitutions are made and improper documentation is maintained. The continuous input from all partners is integral in creating an accurate and representative life cycle assessment. 


\begin{tabular}{|l|l|}
\hline Industry Partner & Role \\
\hline Evergreen Brickworks & Client \\
\hline EllisDon Corporation & General Contractor \\
\hline Brookfield Global Integrated Solutions & Mechanical Engineer \\
\hline LGA Architects & Architect \\
\hline ERA Architects & Heritage Consultation \\
\hline ARUP & Structural Engineer \\
\hline Ianuzziello \& Associates & Electrical Engineer \\
\hline CRH Canada & Manufacturing \\
\hline SCS Consulting Group & Civil Engineer \\
\hline Waverly Projects & Project Manager \\
\hline
\end{tabular}

\subsubsection{Construction Details}

A complete building material specification summary can be found in the Appendix including all specified material properties, manufacturers, products and thicknesses. Envelope assembly details and construction drawings provided by LGA architects are also found in the Appendix.

\subsubsection{Exterior Walls}

The existing double wythe brick walls on the first storey are denoted by the Ontario Heritage Act (Part IV (34)) as part of the existing structure that cannot be removed or altered. The south facing gable above the existing exterior wall features opaque, insulated metal panels. The total exterior wall area is $1,438 \mathrm{~m}^{2}$.

\subsubsection{Curtain Wall}

The west facing exterior façade, currently open to the elements, is being enclosed with an insulated glazing unit curtain wall system that is tempered and has a low-e coating. A portion of the west facing curtain wall is operable, sliding on a top and bottom rolling system. The north facing gable above the existing exterior wall features a similar curtain wall system that is inoperable. The total curtain wall area is $262 \mathrm{~m}^{2}$. 


\subsubsection{Service Room Addition}

The service room addition on the east side of the building features an exterior brick veneer to match the existing to the same elevation as the existing service room and composite metal paneling above, with an extruded polystyrene layer, an air barrier membrane, sheathing, steel stud cavity filled with mineral wool batt insulation, a vapour barrier and cement board on the interior. The total area of wall with this assembly is $117 \mathrm{~m}^{2}$.

\subsubsection{Interior Partitions and Ceilings}

Details of the interior partitions and ceilings can be found in the Appendix. Grout filled concrete masonry units (CMU) made up the structure of all interior partitions with various finishes dependent on location.

\subsubsection{Typical Flooring}

The new concrete slab is designed to top the existing slab adding height to the floors to mitigate flood risk on the interior space. In order to minimize material, plastic, air-filled dome forms are used to create large air-voids in the concrete, requiring significantly less material than a typical concrete slab. The system is topped with insulated concrete and a polished concrete top with radiant tubing and wire mesh.

\subsubsection{Typical Roof}

A corrugated metal roofing system is designed to top the existing metal roof to add thermal resistance and extend the lifetime of the roof. The new roofing assembly includes a 24-gauge ribbed metal roof, vapour barrier and polyisocyanurate insulation.

\subsubsection{Building Integrated Modelling (BIM)}

Arup Engineering provided a preliminary AutoDesk Revit model for the use of this research including the location and dimensions of the exterior walls, roof, floors, interior partitions and service room addition. The model included the shell for the existing conditions, Phase 1 and 
Phase 2. The Revit model provided by Arup Engineering did not include the designation of materials, differences in assemblies or the completed structural components. The Revit model was then modified to include the materials and assembly allocations to ensure accurate material take-offs used in the bill of materials. Table 5 summarizes the bill of materials area quantity take-offs extracted from the AutoDesk Revit model.

Table 5: Bill of Material Quantity Take-Off per the Brickworks Kilns AutoDesk Revit Model

\begin{tabular}{|l|l|}
\hline Assembly & Area $\left.\mathbf{( m}^{2}\right)$ \\
\hline Exterior Walls & $1,565.51$ \\
\hline Partitioning Walls & 383.69 \\
\hline Roof & $5,356.69$ \\
\hline Ceiling & 191.97 \\
\hline Floor & $2,776.73$ \\
\hline Curtain Wall & 523.90 \\
\hline Windows & 18.06 \\
\hline Doors & 121.84 \\
\hline
\end{tabular}

\subsubsection{Greenhouse Gas Emissions Sources}

Given the known parameters of the case study, Table 6 summarizes the greenhouse gas emissions source scope that the Evergreen Brickworks design team intends to include in the life cycle assessment used to quantify the amount of carbon over the life time of the building. The total sum of carbon emissions accumulated over the lifetime of the building must then be sequestered or off-set to achieve carbon neutrality.

Because the project is an adaptive reuse project where the building footprint remains the same and existing materials are used, the building does not experience emissions due to land use changes and site works. The design team also decided not to include the emissions associated with human travel (business travel by employees, site team travel to site, travel to and from site by visitors and staff) and the emissions used by the design team during the design process (office 
lighting, heating, water use). The emissions used by the construction team on site are included (lighting, heating, water used in the site trailer).

Table 6: Emissions by Project Phase of Evergreen Brickworks Kilns Case Study

\begin{tabular}{|c|c|c|c|}
\hline & LCA Phase & Emission Source & $\begin{array}{c}\text { Emission } \\
\text { Scope [as } \\
\text { defined in } \\
\text { Table 1] } \\
\end{array}$ \\
\hline \multirow{4}{*}{$\begin{array}{l}\text { Product } \\
\text { Stage }\end{array}$} & $\begin{array}{l}\text { A1 - Raw Material } \\
\text { Extraction }\end{array}$ & $\begin{array}{l}\text { Raw material extraction of all new } \\
\text { material }\end{array}$ & Scope 3 \\
\hline & \multirow[t]{2}{*}{ A2 - Interim Transportation } & $\begin{array}{l}\text { Transportation of raw material and } \\
\text { recycled material to manufacturing } \\
\text { plant }\end{array}$ & Scope 3 \\
\hline & & Transportation between plant facilities & Scope 3 \\
\hline & A3 - Manufacturing & $\begin{array}{l}\text { Off-site material manufacturing and } \\
\text { assembly }\end{array}$ & Scope 3 \\
\hline \multirow{5}{*}{$\begin{array}{l}\text { Construction } \\
\text { Stage }\end{array}$} & A4 - Transportation to Site & $\begin{array}{l}\text { Material and machinery transportation } \\
\text { to site }\end{array}$ & Scope 3 \\
\hline & \multirow{4}{*}{$\begin{array}{l}\text { A5 - Construction } \\
\text { Processes }\end{array}$} & On-site building component assembly & Scope 2 \\
\hline & & $\begin{array}{l}\text { Site team trailer utilities (water, } \\
\text { electricity, heating) }\end{array}$ & Scope 2 \\
\hline & & $\begin{array}{l}\text { Removal and disposal of construction } \\
\text { material waste }\end{array}$ & Scope 3 \\
\hline & & On-site machinery operation & Scope 2 \\
\hline \multirow{10}{*}{ Use } & B1 - Use & $N / A$ & \\
\hline & \multirow[t]{2}{*}{ B2 - Maintenance } & $\begin{array}{l}\text { Mechanical and electrical equipment } \\
\text { maintenance }\end{array}$ & Scope 3 \\
\hline & & General building maintenance & Scope 3 \\
\hline & \multirow[t]{2}{*}{ B3 - Repair } & $\begin{array}{l}\text { Mechanical and electrical equipment } \\
\text { repair }\end{array}$ & Scope 3 \\
\hline & & Construction material repair & Scope 3 \\
\hline & \multirow[t]{2}{*}{ B4 - Replacement } & $\begin{array}{l}\text { Mechanical and electrical equipment } \\
\text { replacement }\end{array}$ & Scope 3 \\
\hline & & Construction material replacement & Scope 3 \\
\hline & \multirow[t]{2}{*}{ B5 - Refurbishment } & $\begin{array}{l}\text { Mechanical and electrical equipment } \\
\text { replacement }\end{array}$ & Scope 3 \\
\hline & & Construction material refurbishment & Scope 3 \\
\hline & B6 - Operational Energy & $\begin{array}{l}\text { Electricity used for radiant in-floor } \\
\text { heating }\end{array}$ & Scope 2 \\
\hline
\end{tabular}




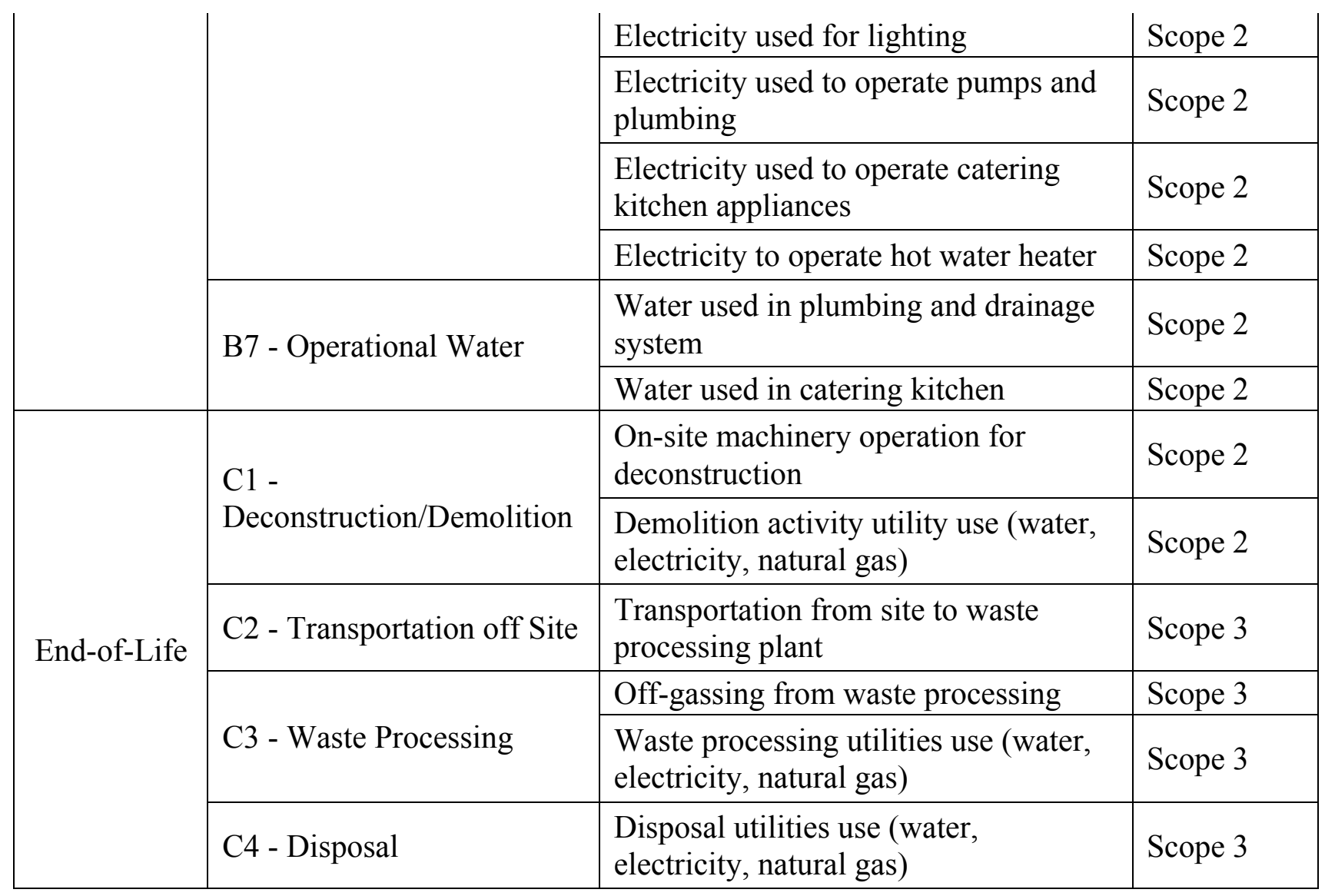

\subsubsection{Data Collection}

Obtaining detailed data for the Evergreen Brickworks Kilns project prior to construction completion proved to be difficult as Phase 2 of the project only went to Tender in July 2017, meaning the specific materials have not been selected and therefore the EPDs are not readily available. While much of the data will be eventually obtained, a significant number of assumptions and averages were necessary to obtain results at the current stage of the project. Additionally, because the project is in-progress, design changes and as-built conditions are not reflected in the models. 


\subsection{Case Study Inputs}

\subsubsection{Product Stage (A1-A3)}

Table 7 summarizes the material inputs into each LCA tool, given the project specification and contract document. A complete list by assembly type and specification section can be found in the Appendix. As identified in the table, some major discrepancies between available materials in the program databases consequently mean some materials cannot be fairly compared side-byside.

While the Brickworks project has specified in all subcontractor's Schedule A that EPDs are required for all materials installed on site, this process is ongoing and no EPDs have been submitted to date. For this reason, the specific material and manufacturer's EPD are not reflected in the LCA models. Materials were selected in all cases to match the project specification to the closest degree given the material database available in each program.

Because One-Click LCA relies entirely on EPDs and does not have any generic material inputs with the exception of concrete which are generic from the Canadian Ready Mix Concrete Association (CRMCA), only products that have been third-party verified are included in the database. Therefore, the One-Click LCA Brickworks Kilns model does not have an input for the specifies air barrier self-adhering membrane as there are no EPDs listed for the specified product or similar.

Finishes such as paints, drywall tape, screws, nuts and bolts were excluded from the models as quantifying these materials cannot be simply estimated by a specified unit of measure as they are not included of the Brickworks Kilns AutoDesk Revit model.

The implications of inconsistent construction material inputs have a significant impact on the reported carbon in each model. As seen in Table 7, the material differences in some cases are so great that products in reality should not be compared. Resulting differences from product selection are discussed in detail in the case study results. 


\begin{tabular}{|c|c|c|c|c|c|}
\hline \multicolumn{3}{|c|}{ Specified Material } & One Click & Tally & Athena \\
\hline $\begin{array}{l}\text { Material } \\
\text { Name }\end{array}$ & $\begin{array}{c}\text { Approved } \\
\text { Manufacturer }\end{array}$ & Product Name & Product & Product & Product \\
\hline \multicolumn{6}{|c|}{ Walls } \\
\hline $\begin{array}{l}\text { Air Barrier } \\
\text { Self- } \\
\text { Adhering } \\
\text { Membrane }\end{array}$ & $\begin{array}{l}\text { Cosella-Dorken/ } \\
\text { Henry Company } \\
\text { Canada Inc./ } \\
\text { Vaproshield }\end{array}$ & $\begin{array}{l}\text { Delta-Vent SA/ } \\
\text { Blueskin } \\
\text { VP160/ } \\
\text { WrapShield } \\
\text { SA }\end{array}$ & & $\begin{array}{l}\text { Self-adhering } \\
\text { 40mil } \\
\text { membrane }\end{array}$ & Air Barrier \\
\hline $\begin{array}{l}\text { Brick, to } \\
\text { match } \\
\text { existing }\end{array}$ & $\begin{array}{l}\text { Mortar Type N, } \\
\text { exterior non-load } \\
\text { bearing }\end{array}$ & & $\begin{array}{l}\text { Concrete } \\
\text { Masonry } \\
\text { Unit, } 7 \\
7 / 8 \text { inx } 7 \\
\text { 5/8inx15 } \\
\text { 5/8in, HW } \\
\text { Regular }\end{array}$ & $\begin{array}{l}\text { Brick, grouted } \\
\text { with mortar } \\
\text { type } \mathrm{N}\end{array}$ & Concrete Brick \\
\hline $\begin{array}{l}\text { Cement } \\
\text { Board }\end{array}$ & CGC Inc. & $\begin{array}{l}\text { Durock } \\
\text { Cement Board } \\
\text { Next Gen }\end{array}$ & $\begin{array}{l}\text { Medium } \\
\text { density } \\
\text { fibreboard, } \\
0.75 \mathrm{in}\end{array}$ & $\begin{array}{l}\text { Cement } \\
\text { bonded } \\
\text { particle board }\end{array}$ & Fiber Cement \\
\hline $\begin{array}{l}\text { CMU Filled } \\
\text { with Grout, } \\
\text { mortar type } \\
\text { S, } \\
\text { reinforced } \\
\text { with hot } \\
\text { dipped } \\
\text { galvanized }\end{array}$ & & & $\begin{array}{l}\text { Concrete } \\
\text { Masonry } \\
\text { Unit }\end{array}$ & $\begin{array}{l}\text { Hollow core } \\
\text { CMU, } \\
\text { grouted, } \\
6 \times 8 \times 16, \\
\text { Mortar type S, } \\
\text { reinforcing } \\
\text { steel rod @ } \\
48 " \text { o.c. }\end{array}$ & $\begin{array}{l}\text { 6" Normal } \\
\text { Weight } \\
\text { Concrete Block }\end{array}$ \\
\hline $\begin{array}{l}\text { Exterior } \\
\text { Sheathing }\end{array}$ & $\begin{array}{l}\text { CertainTeed Gypsum } \\
\text { Canada/ CGC Inc/ } \\
\text { Georgia-Pacific } \\
\text { Canada LP }\end{array}$ & $\begin{array}{l}\text { GlasRoc Brand } \\
\text { Sheathing/ } \\
\text { Securock } \\
\text { Glass-Mat } \\
\text { Sheathing/ } \\
\text { Dens-Glass } \\
\text { Gold }\end{array}$ & $\begin{array}{l}\text { Gypsum } \\
\text { Board Type } \\
\text { X, 5/8", } 2.25 \\
\text { psf }\end{array}$ & $\begin{array}{l}\text { Fibreglass } \\
\text { mat gypsum } \\
\text { sheathing }\end{array}$ & $\begin{array}{l}\text { 1/2" Moisture } \\
\text { Resistant } \\
\text { Gypsum Board }\end{array}$ \\
\hline $\begin{array}{l}\text { Furring } \\
\text { Channels }\end{array}$ & & $\begin{array}{l}0.5 \mathrm{~mm} \text { base } \\
\text { steel thickness, } \\
\text { galvanized. } \\
70 \mathrm{~mm} \text { wide } \mathrm{x} \\
22 \mathrm{~mm} \text { deep } \\
\text { hat shaped } \\
\text { channel }\end{array}$ & $\begin{array}{l}\text { Steel } \\
\text { Framing } \\
\text { Systems }\end{array}$ & $\begin{array}{l}\text { Steel, furring } \\
\text { channels, } \\
\text { galvanized } \\
7 / 8 " 25 \mathrm{Ga} \text {. }\end{array}$ & $\begin{array}{l}\text { Galvanized } \\
\text { Studs }\end{array}$ \\
\hline $\begin{array}{l}\text { Insulated } \\
\text { Metal Panel }\end{array}$ & AWIPanels/VicWest & $\begin{array}{l}\text { F40 "Flat } \\
\text { Wall" }\end{array}$ & $\begin{array}{l}\text { Insulated } \\
\text { metal panel, } \\
13 / 4 \mathrm{in}-4 \mathrm{in} \times \\
36 \mathrm{in} \times 6 \mathrm{in}- \\
48 \mathrm{ft}\end{array}$ & $\begin{array}{l}\text { Spandrel, } \\
\text { aluminum, } \\
\text { insulated (2" } \\
\text { core) }\end{array}$ & $\begin{array}{l}3 " \text { Insulated } \\
\text { Metal Panel }\end{array}$ \\
\hline
\end{tabular}




\begin{tabular}{|c|c|c|c|c|c|}
\hline \multicolumn{3}{|c|}{ Specified Material } & One Click & Tally & Athena \\
\hline $\begin{array}{l}\text { Material } \\
\text { Name }\end{array}$ & $\begin{array}{c}\text { Approved } \\
\text { Manufacturer }\end{array}$ & Product Name & Product & Product & Product \\
\hline $\begin{array}{l}\text { Mineral } \\
\text { Wool Batt } \\
\text { Insulation }\end{array}$ & Roxul & ComfortBatt & $\begin{array}{l}\text { Mineral wool } \\
\text { insulation } \\
\text { batt, R30, } \\
\text { EcoBatt } \\
\text { Insulation } \\
\text { with Ecose } \\
\text { Technology }\end{array}$ & $\begin{array}{l}\text { Mineral wool } \\
\text { (rockwool) } \\
\text { rigid } \\
\text { insulation } \\
\text { board, low } \\
\text { density }\end{array}$ & MW Batt R30 \\
\hline $\begin{array}{l}\text { Patterned } \\
\text { Back } \\
\text { Painted } \\
\text { Glass }\end{array}$ & & & $\begin{array}{l}\text { Pressed glass } \\
\text { partition, } \\
0.236 \text { in }\end{array}$ & $\begin{array}{l}\text { Glazing, } \\
\text { monolithic } \\
\text { sheet }\end{array}$ & Glazing Panel \\
\hline $\begin{array}{l}\text { Pre-finished } \\
\text { composite } \\
\text { metal panels }\end{array}$ & $\begin{array}{l}\text { Flynn Canada Ltd/ } \\
\text { Vicwest Canada/ } \\
\text { Exterior } \\
\text { Technologies Group }\end{array}$ & $\begin{array}{l}\text { Accumet PE/ } \\
\text { ACM Panels/ } \\
\text { Alpolic Panels }\end{array}$ & $\begin{array}{l}\text { Roll formed } \\
\text { steel panels, } \\
24 \text { gauge, } 5.9 \\
\mathrm{~kg} / \mathrm{m} 2\end{array}$ & $\begin{array}{l}\text { Aluminum, } \\
\text { sheet }\end{array}$ & $\begin{array}{l}\text { Metal Wall } \\
\text { Cladding - } \\
\text { Commercial } \\
(26 \mathrm{Ga})\end{array}$ \\
\hline $\begin{array}{l}\text { Resilient } \\
\text { Channel }\end{array}$ & & $\begin{array}{l}0.5 \mathrm{~mm} \text { thick } \\
\text { galvanized } \\
\text { metal, } 57 \mathrm{~mm} \\
\text { wide } \mathrm{x} 12 \\
\text { mm deep }\end{array}$ & $\begin{array}{l}\text { Steel } \\
\text { Framing } \\
\text { System }\end{array}$ & $\begin{array}{l}\text { Galvanized } \\
\text { Steel "Z"' } \\
\text { Channel }\end{array}$ & $\begin{array}{l}\text { Galvanized } \\
\text { Studs }\end{array}$ \\
\hline $\begin{array}{l}\text { Rigid } \\
\text { Insulation } \\
\text { XPS } \\
\text { Horizontal }\end{array}$ & $\begin{array}{l}\text { Dow Cornings } \\
\text { Canada/ Owens } \\
\text { Cornings Canada }\end{array}$ & $\begin{array}{l}\text { Styrofoam SM/ } \\
\text { Foamular C- } \\
300\end{array}$ & $\begin{array}{l}\text { XPS } \\
\text { Insulation } \\
\text { (extruded } \\
\text { polystyrene) }\end{array}$ & $\begin{array}{l}\text { Extruded } \\
\text { Polystyrene, } \\
\text { XPS }\end{array}$ & $\begin{array}{l}\text { Extruded } \\
\text { Polystyrene }\end{array}$ \\
\hline $\begin{array}{l}\text { Steel Stud, } \\
\text { 405mm o.c. }\end{array}$ & $\begin{array}{l}\text { Bailey Metal } \\
\text { Products/ Sanders } \\
\text { Steel Inc./ Steelform } \\
\text { Building Products }\end{array}$ & $\begin{array}{l}\text { CSA S136, } \\
\text { Grade A to D } \\
\text { steel with Z275 } \\
\text { zinc coating } \\
\text { designation in } \\
\text { accordance } \\
\text { with ASTM } \\
\text { A653/A653M }\end{array}$ & $\begin{array}{l}\text { Steel } \\
\text { Framing } \\
\text { System }\end{array}$ & $\begin{array}{l}\text { Steel, C-stud } \\
\text { metal } \\
\text { framing, } \\
\text { galvanized } \\
\text { with } \\
\text { insulation, } 1 \\
\text { way spacing } \\
\text { 405mm o.c. }\end{array}$ & $\begin{array}{l}\text { Galvanized } \\
\text { Studs }\end{array}$ \\
\hline Tile finish & & & $\begin{array}{l}\text { Bio-based } \\
\text { Floor Tile }\end{array}$ & $\begin{array}{l}\text { Ceramic Tile, } \\
\text { unglazed, } \\
\text { inclusive of } \\
\text { mortar }\end{array}$ & Clay Tile \\
\hline $\begin{array}{l}\text { Vapour } \\
\text { Barrier }\end{array}$ & & $\begin{array}{l}\text { Polyethylene } \\
\text { film } 6 \mathrm{mil}\end{array}$ & $\begin{array}{l}\text { Vapor } \\
\text { Barrier, } \\
0.06 \text { in }\end{array}$ & $\begin{array}{l}\text { Polyethylene } \\
\text { sheet vapor } \\
\text { barrier } \\
\text { (HDPE) }\end{array}$ & $\begin{array}{l}\text { VR Protection } \\
\text { Sheet }\end{array}$ \\
\hline
\end{tabular}




\begin{tabular}{|c|c|c|c|c|c|}
\hline \multicolumn{3}{|c|}{ Specified Material } & One Click & Tally & Athena \\
\hline $\begin{array}{c}\text { Material } \\
\text { Name }\end{array}$ & $\begin{array}{c}\text { Approved } \\
\text { Manufacturer }\end{array}$ & Product Name & Product & Product & Product \\
\hline \multicolumn{6}{|c|}{ Windows } \\
\hline $\begin{array}{l}\text { Type 1: } \\
\text { FGL }\end{array}$ & $\begin{array}{l}\text { AGC Flat Glass/ } \\
\text { Cardinal Glass } \\
\text { Industries/ Guardian } \\
\text { Industries/ Oldcastle } \\
\text { Glass Inc/ PPG } \\
\text { Industries Ltd./ } \\
\text { Viracon Inc. }\end{array}$ & $\begin{array}{l}\text { Double Pane, } \\
\text { Float Glass, } \\
\text { low-e coating }\end{array}$ & $\begin{array}{l}\text { Traditional } \\
\text { Curtain Wall, } \\
1.5 \mathrm{mx} 1.6 \mathrm{~m} \\
\text { and } \\
\text { Clearwall } \\
\text { curtain wall } \\
\text { system }\end{array}$ & $\begin{array}{l}\text { Glazing, double } \\
\text { pane IGU, } 2 \\
\text { layers of } 4 \mathrm{~mm} \\
\text { thick glass, air } \\
\text { filled, low-e }\end{array}$ & $\begin{array}{l}\text { Double } \\
\text { Glazed } \\
\text { Hard } \\
\text { Coated Air }\end{array}$ \\
\hline $\begin{array}{l}\text { Type 2: } \\
\text { TGL }\end{array}$ & $\begin{array}{l}\text { AGC Flat Glass/ } \\
\text { Cardinal Glass } \\
\text { Industries/ Guardian } \\
\text { Industries/ Oldcastle } \\
\text { Glass Inc/ PPG } \\
\text { Industries Ltd./ } \\
\text { Viracon Inc. }\end{array}$ & $\begin{array}{l}\text { Double Pane, } \\
\text { Tempered, } \\
\text { low-e coating }\end{array}$ & $\begin{array}{l}\text { Traditional } \\
\text { Curtain Wall, } \\
1.5 \mathrm{mx} 1.6 \mathrm{~m} \\
\text { and } \\
\text { Clearwall } \\
\text { curtain wall } \\
\text { system }\end{array}$ & $\begin{array}{l}\text { Glazing, double } \\
\text { pane IGU, } 2 \\
\text { layers of } 4 \mathrm{~mm} \\
\text { thick glass, air } \\
\text { filled, low-e }\end{array}$ & $\begin{array}{l}\text { Double } \\
\text { Glazed } \\
\text { Hard } \\
\text { Coated Air }\end{array}$ \\
\hline \multicolumn{6}{|c|}{ Roof } \\
\hline $\begin{array}{l}2 \text { Lb Spray } \\
\text { Insulation }\end{array}$ & BASF/ Demilec Inc. & $\begin{array}{l}\text { Walltite Eco } \\
\text { v.3/ Heatlok } \\
\text { Soya }\end{array}$ & $\begin{array}{l}\text { Spray foam } \\
\text { insulation, } \\
1.02 \text { in }\end{array}$ & $\begin{array}{l}\text { Open cell spray } \\
\text { foam applied } \\
\text { polyurethane } \\
\text { foam }\end{array}$ & $\begin{array}{l}\text { FG LF } \\
\text { Open Blow } \\
\text { R31-40 }\end{array}$ \\
\hline $\begin{array}{l}24 \mathrm{Ga} . \\
\text { Ribbed } \\
\text { Metal Roof }\end{array}$ & $\begin{array}{l}\text { Agway Metals Inc./ } \\
\text { Roll From Group/ } \\
\text { VicWest Steel }\end{array}$ & $\begin{array}{l}\text { Z275, } \\
\text { Galvanized } \\
\text { steel }\end{array}$ & $\begin{array}{l}\text { Steel roof } \\
\text { and floor } \\
\text { deck, 22-16 } \\
\text { gauge }\end{array}$ & $\begin{array}{l}\text { Steel, roof } \\
\text { decking, cold- } \\
\text { formed } \\
\text { galvanized }\end{array}$ & $\begin{array}{l}\text { MBS Metal } \\
\text { Roof } \\
\text { Cladding - } \\
\text { Commercial } \\
(24 \mathrm{Ga})\end{array}$ \\
\hline $\begin{array}{l}\text { 2-Ply } \\
\text { Modified } \\
\text { Bitumen } \\
\text { Roofing } \\
\text { System }\end{array}$ & $\begin{array}{l}\text { Henry Company } \\
\text { Canada Inc./ Siplast/ } \\
\text { Soprema } \\
\text { Waterproofing Inc. }\end{array}$ & $\begin{array}{l}2 \text { Sheet } \\
\text { Styrene- } \\
\text { Butadiene- } \\
\text { Styrene (SBS) } \\
\text { Membrane }\end{array}$ & $\begin{array}{l}\text { Fluid } \\
\text { Applied } \\
\text { Rubber } \\
\text { Asphalt } \\
\text { roofing }\end{array}$ & $\begin{array}{l}\text { Self-adhering } \\
\text { sheet } \\
\text { waterproofing, } \\
\text { modified } \\
\text { bituminous sheet }\end{array}$ & $\begin{array}{l}\text { Modified } \\
\text { Bitumen } \\
\text { Membrane }\end{array}$ \\
\hline $\begin{array}{l}\text { Cement } \\
\text { Board }\end{array}$ & CGC Inc. & $\begin{array}{l}\text { Durock } \\
\text { Cement Board } \\
\text { Next Gen }\end{array}$ & $\begin{array}{l}\text { Medium } \\
\text { density } \\
\text { fibreboard, } \\
0.75 \mathrm{in}\end{array}$ & $\begin{array}{l}\text { Cement bonded } \\
\text { particle board }\end{array}$ & Fiber Board \\
\hline $\begin{array}{l}\text { Corrugated } \\
\text { Metal Deck }\end{array}$ & $\begin{array}{l}\text { Agway Metals Inc./ } \\
\text { Roll From Group/ } \\
\text { VicWest Steel }\end{array}$ & $\begin{array}{l}Z 275, \\
\text { Galvanized } \\
\text { steel }\end{array}$ & $\begin{array}{l}\text { Composite } \\
\text { Metal } \\
\text { Decking, } 30 \\
\text { mil }\end{array}$ & $\begin{array}{l}\text { Steel, form deck, } \\
\text { cold-galvanized }\end{array}$ & $\begin{array}{l}\text { Galvanized } \\
\text { Decking }\end{array}$ \\
\hline $\begin{array}{l}\text { Exterior } \\
\text { Sheathing }\end{array}$ & $\begin{array}{l}\text { CertainTeed Gypsum } \\
\text { Canada/ CGC Inc/ } \\
\text { Georgia-Pacific } \\
\text { Canada LP }\end{array}$ & $\begin{array}{l}\text { GlasRoc Brand } \\
\text { Sheathing/ } \\
\text { Securock } \\
\text { Glass-Mat } \\
\text { Sheathing/ } \\
\text { Dens-Glass } \\
\text { Gold }\end{array}$ & $\begin{array}{l}\text { Gypsum } \\
\text { Board Type } \\
X, 5 / 8^{\prime \prime}, 2.25 \\
\text { psf }\end{array}$ & $\begin{array}{l}\text { Fibreglass mat } \\
\text { gypsum sheathing }\end{array}$ & $\begin{array}{l}1 / 2 " \\
\text { Moisture } \\
\text { Resistant } \\
\text { Gypsum } \\
\text { Board }\end{array}$ \\
\hline
\end{tabular}




\begin{tabular}{|c|c|c|c|c|c|}
\hline \multicolumn{3}{|c|}{ Specified Material } & One Click & Tally & Athena \\
\hline $\begin{array}{c}\text { Material } \\
\text { Name }\end{array}$ & $\begin{array}{c}\text { Approved } \\
\text { Manufacturer }\end{array}$ & Product Name & Product & Product & Product \\
\hline $\begin{array}{l}\text { Rigid Poly } \\
\text { Iso } \\
\text { Insulation }\end{array}$ & $\begin{array}{l}\text { Dow Cornings } \\
\text { Canada/ Owens } \\
\text { Cornings Canada }\end{array}$ & $\begin{array}{l}\text { Styrofoam SM/ } \\
\text { Foamular C- } \\
300\end{array}$ & $\begin{array}{l}\text { ISO foam } \\
\text { insulation, } \\
0.5-2 \text { in, Tuff- } \\
\text { R Insulation } \\
\text { (Dow) }\end{array}$ & $\begin{array}{l}\text { Polyisocyanurate } \\
\text { (PIR) board }\end{array}$ & $\begin{array}{l}\text { Polyiso } \\
\text { foam board }\end{array}$ \\
\hline $\begin{array}{l}\text { Vapour } \\
\text { Permeable } \\
\text { Self } \\
\text { Adhering } \\
\text { Membrane }\end{array}$ & & $\begin{array}{l}\text { Polyethylene } \\
\text { film 6mil }\end{array}$ & $\begin{array}{l}\text { Vapor } \\
\text { Barrier, } \\
0.06 \mathrm{in}\end{array}$ & $\begin{array}{l}\text { Polyethylene } \\
\text { sheet vapor } \\
\text { barrier (HDPE) }\end{array}$ & $\begin{array}{l}\text { VR } \\
\text { Protection } \\
\text { Sheet }\end{array}$ \\
\hline \multicolumn{6}{|c|}{ Ceiling } \\
\hline $\begin{array}{l}\text { Gypsum } \\
\text { Wall Board }\end{array}$ & $\begin{array}{l}\text { Certainteed Gypsum } \\
\text { Canada, CGC Inc./ } \\
\text { Georgia-Pacific } \\
\text { Canada LP }\end{array}$ & Furnish Board & $\begin{array}{l}\text { Gypsum } \\
\text { Wall Board, } \\
\text { Regular, } \\
0.5 \text { in }\end{array}$ & $\begin{array}{l}\text { Wall board, } \\
\text { gypsum, interior } \\
\text { acrylic latex paint }\end{array}$ & $\begin{array}{l}1 / 2 " \\
\text { Regular } \\
\text { Gypsum } \\
\text { Board }\end{array}$ \\
\hline Metal Stud & $\begin{array}{l}\text { Bailey Metal } \\
\text { Products/ Sanders } \\
\text { Steel Inc./ Steelform } \\
\text { Building Products }\end{array}$ & $\begin{array}{l}\text { CSA S136, } \\
\text { Grade A to D } \\
\text { steel with Z275 } \\
\text { zinc coating } \\
\text { designation in } \\
\text { accordance } \\
\text { with ASTM } \\
\text { A653/A653M }\end{array}$ & $\begin{array}{l}\text { Steel } \\
\text { Framing } \\
\text { System }\end{array}$ & $\begin{array}{l}\text { Steel, C-stud } \\
\text { metal framing, } \\
\text { galvanized with } \\
\text { insulation, 1 way } \\
\text { spacing } 405 \mathrm{~mm} \\
\text { o.c. }\end{array}$ & $\begin{array}{l}\text { Galvanized } \\
\text { Studs }\end{array}$ \\
\hline $\begin{array}{l}\text { Mineral } \\
\text { Wool } \\
\text { Acoustical } \\
\text { Batts }\end{array}$ & Roxul & ComfortBatt & $\begin{array}{l}\text { Mineral wool } \\
\text { insulation } \\
\text { batt, R30, } \\
\text { EcoBatt } \\
\text { Insulation } \\
\text { with Ecose } \\
\text { Technology }\end{array}$ & $\begin{array}{l}\text { Mineral wool, low } \\
\text { density }\end{array}$ & $\begin{array}{l}\text { MW Batt } \\
\text { R30 }\end{array}$ \\
\hline $\begin{array}{l}\text { Reinforced } \\
\text { Concrete }\end{array}$ & & & $\begin{array}{l}\text { Ready-mix } \\
\text { concrete, } 25 \\
\text { MPa GU } \\
\text { cement with } \\
\text { air entrained } \\
0-14 \% \text {, with } \\
\text { rebar, hot } \\
\text { rolled }\end{array}$ & $\begin{array}{l}\text { Reinforced slab } \\
3000 \text { psi, } \\
\text { exclusive of deck }\end{array}$ & $\begin{array}{l}\text { Concrete } \\
\text { Benchmark } \\
2500 \mathrm{psi} \text {, } \\
\text { with rebar, } \\
\text { rod, light } \\
\text { sections }\end{array}$ \\
\hline $\begin{array}{l}\text { Resilient } \\
\text { Channel }\end{array}$ & & $\begin{array}{l}0.5 \mathrm{~mm} \text { thick } \\
\text { galvanized } \\
\text { metal, } 57 \mathrm{~mm} \\
\text { wide x } 12 \\
\text { mm deep }\end{array}$ & $\begin{array}{l}\text { Steel } \\
\text { Framing } \\
\text { System }\end{array}$ & $\begin{array}{l}\text { Galvanized Steel } \\
\text { "Z" Channel }\end{array}$ & $\begin{array}{l}\text { Galvanized } \\
\text { Studs }\end{array}$ \\
\hline Steel Deck & $\begin{array}{l}\text { Agway Metals Inc./ } \\
\text { Roll From Group/ } \\
\text { VicWest Steel }\end{array}$ & $\begin{array}{l}\text { Z275, } \\
\text { Galvanized } \\
\text { steel }\end{array}$ & $\begin{array}{l}\text { Steel roof } \\
\text { and floor } \\
\text { deck, 22-16 } \\
\text { gauge }\end{array}$ & $\begin{array}{l}\text { Steel, roof } \\
\text { decking, cold- } \\
\text { formed } \\
\text { galvanized }\end{array}$ & $\begin{array}{l}\text { Galvanized } \\
\text { Decking }\end{array}$ \\
\hline
\end{tabular}




\begin{tabular}{|c|c|c|c|c|c|}
\hline \multicolumn{3}{|c|}{ Specified Material } & One Click & Tally & Athena \\
\hline $\begin{array}{l}\text { Material } \\
\text { Name }\end{array}$ & $\begin{array}{c}\text { Approved } \\
\text { Manufacturer }\end{array}$ & Product Name & Product & Product & Product \\
\hline \multicolumn{6}{|c|}{ Floors } \\
\hline $\begin{array}{l}\text { Concrete } \\
\text { Finish }\end{array}$ & & & $\begin{array}{l}\text { Ready-mix } \\
\text { concrete, } 25 \\
\text { MPa GU } \\
\text { with air } \\
\text { entrained 0- } \\
14 \%\end{array}$ & $\begin{array}{l}\text { Structural, } \\
\text { unreinforced, } \\
3000 \mathrm{psi} / 20 \mathrm{MPa}\end{array}$ & $\begin{array}{l}\text { Concrete } \\
\text { Benchmark } \\
\text { 3000psi }\end{array}$ \\
\hline $\begin{array}{l}\text { Insulated } \\
\text { Concrete } \\
\text { (R10) }\end{array}$ & Foamcrete & $\begin{array}{l}\text { Dufferin } \\
\text { Concrete }\end{array}$ & $\begin{array}{l}\text { Ready-mix } \\
\text { concrete, } 25 \\
\text { MPa GU } \\
\text { with air } \\
\text { entrained 0- } \\
14 \%\end{array}$ & $\begin{array}{l}\text { Air-Entrained } \\
\text { Structural } \\
\text { concrete, } \\
\text { unreinforced }\end{array}$ & $\begin{array}{l}\text { Concrete } \\
\text { Benchmark } \\
\text { 4000psi }\end{array}$ \\
\hline $\begin{array}{l}\text { Polished } \\
\text { Concrete } \\
\text { with radiant } \\
\text { and wire } \\
\text { mesh }\end{array}$ & & & $\begin{array}{l}\text { Ready-mix } \\
\text { concrete, } 25 \\
\text { Mpa GU } \\
\text { with air } \\
\text { entrained 0- } \\
14 \%\end{array}$ & $\begin{array}{l}\text { Structural, } \\
\text { unreinforced, } \\
3000 \mathrm{psi} / 20 \mathrm{MPa}\end{array}$ & $\begin{array}{l}\text { Concrete } \\
\text { Benchmark } \\
\text { 3000psi }\end{array}$ \\
\hline $\begin{array}{l}\text { Raised } \\
\text { Structural } \\
\text { Cavity floor }\end{array}$ & Cupolex & $\begin{array}{l}\text { Cupolex } \\
\text { Modular } \\
\text { Vaulted Sub- } \\
\text { slab Forms, } 25 \\
\text { MPa }\end{array}$ & $\begin{array}{l}\text { Ready-mix } \\
\text { concrete, } 25 \\
\text { MPa GU } \\
\text { with air } \\
\text { entrained } 0- \\
14 \%\end{array}$ & $\begin{array}{l}\text { Air-Entrained } \\
\text { Structural } \\
\text { concrete, } \\
\text { unreinforced }\end{array}$ & $\begin{array}{l}\text { Concrete } \\
\text { Benchmark } \\
\text { 4000psi }\end{array}$ \\
\hline $\begin{array}{l}\text { Reinforced } \\
\text { Concrete on } \\
\text { Steel Deck }\end{array}$ & & & $\begin{array}{l}\text { Steel roof } \\
\text { and floor } \\
\text { deck, 22-16 } \\
\text { gauge }\end{array}$ & $\begin{array}{l}\text { Steel, cold formed } \\
\text { galvanized deck }\end{array}$ & $\begin{array}{l}\text { Galvanized } \\
\text { Decking }\end{array}$ \\
\hline $\begin{array}{l}\text { Reinforced } \\
\text { Concrete } \\
\text { Slab }\end{array}$ & & & $\begin{array}{l}\text { Ready-mix } \\
\text { concrete, } 25 \\
\text { MPa GU } \\
\text { with air } \\
\text { entrained 0- } \\
\text { 14\%, with } \\
\text { rebar hot } \\
\text { rolled }\end{array}$ & $\begin{array}{l}\text { Cast-in-place } \\
\text { concrete, slab on } \\
\text { grade with } \\
\text { reinforcing steel } \\
\text { inclusive }\end{array}$ & $\begin{array}{l}\text { Concrete } \\
\text { Benchmark } \\
\text { 4000psi } \\
\text { with rebar, } \\
\text { rod light } \\
\text { sections }\end{array}$ \\
\hline
\end{tabular}

\subsubsection{Construction Stage (A4-A5)}

The Brickworks Kilns design team has requested all subcontractors document the vehicle activity to and from the site, including distances from material manufacturer to site, method of transportation and number of trips taken. This information is not utilized in this analysis because the project is still underway and the requested information has not been provided to-date. 
On-site sub-metering is not being done on the Brickworks Kilns project, meaning construction process energy and associated carbon cannot be accurately measured. However, machinery use patterns, hours operated and purpose of use are being documented for further research to develop a better understanding of the energy and carbon implications associated with construction processes.

\subsubsection{Tally}

Default values were used where all materials are transported by truck at varying auto-populated distances generated from the US database. All materials are transported by ground transportation implying all material are local within North America.

Because construction process energy is highly variable and dependent on the project, an assumed value cannot be simply inputted into Tally. For this reason, the construction processes input is not considered in the model.

\subsubsection{Athena Impact Estimator}

As noted, both transportation and construction process energy cannot be modified in Athena Impact Estimator.

\subsubsection{One-Click LCA}

Default values are used for the calculation where the material transportation method selection for all materials is "trailer combination, 40 tonne capacity, $50 \%$ fill rate" and for concrete is "concrete mixer truck, average, $100 \%$ fill rate". Default transportation distances are not disclosed.

The One-Click LCA trial version does not include construction impacts (A5) and therefore is not considered in the model. 


\subsubsection{Use (B1-B7)}

\subsubsection{Tally}

The 1,100,000 kWh/year electricity usage on the Brickworks Kilns project was inputted into Tally with an energy source selection of "Average grid mix - Canada". The lifespan of each material is integrated into the program and cannot be modified.

\subsubsection{Athena Impact Estimator}

The 1,100,000 kWh/year electricity usage on the Brickworks Kilns project was inputted into Athena Impact Estimator with a project location of Toronto. The lifespan of each material is integrated into the program and cannot be modified.

\subsubsection{One-Click LCA}

The 1,100,000 kWh/year electricity usage on the Brickworks Kilns project was inputted into One-Click LCA with an energy source selection of "Electricity, Canada, Ontario" from Statistics Canada 2015.

Default material life spans are used where all envelope and structural components have a life span the same as the building of 60 years, and all interior and exterior finishes, doors, windows and curtain wall have shorted life spans between 20 and 30 years.

\subsubsection{End-of-Life (C1-C4)}

The material inputs selected and back-end program calculations dictate the end-of-life scenario for each project. 


\section{Case Study Results}

The three life cycle assessment tools outputted significantly different results based on the materials selected, detail of materials such as finishes and hardware, program assumptions and averages, and default inputs. While all programs are run using identical material take-offs, each program computes the embodied emissions at each life cycle phase differently.

\subsection{Comparison by Building Element}

Figure 7 compares the three whole building life cycle assessment tools by material category where each category is the sum of the embodied carbon of each material including all life cycle phases. Understandably, the roof and floors are the largest contributors of carbon dioxide given their percent volume of material compared to the walls, curtain wall, windows and doors. The three models show significant discrepancies between model outputs where the Athena Impact Estimator model and Tally model reported a difference of $41 \%$ in carbon emissions in the roof alone. Similarly, the Tally model reported 32\% higher carbon emissions in the floors than both the One-Click LCA and Athen Impact Estimator models. In order to further understand the substantial differences in program outputs, a sensitivity analysis was performed on the two largest contributing material categories, the roof and the floors.

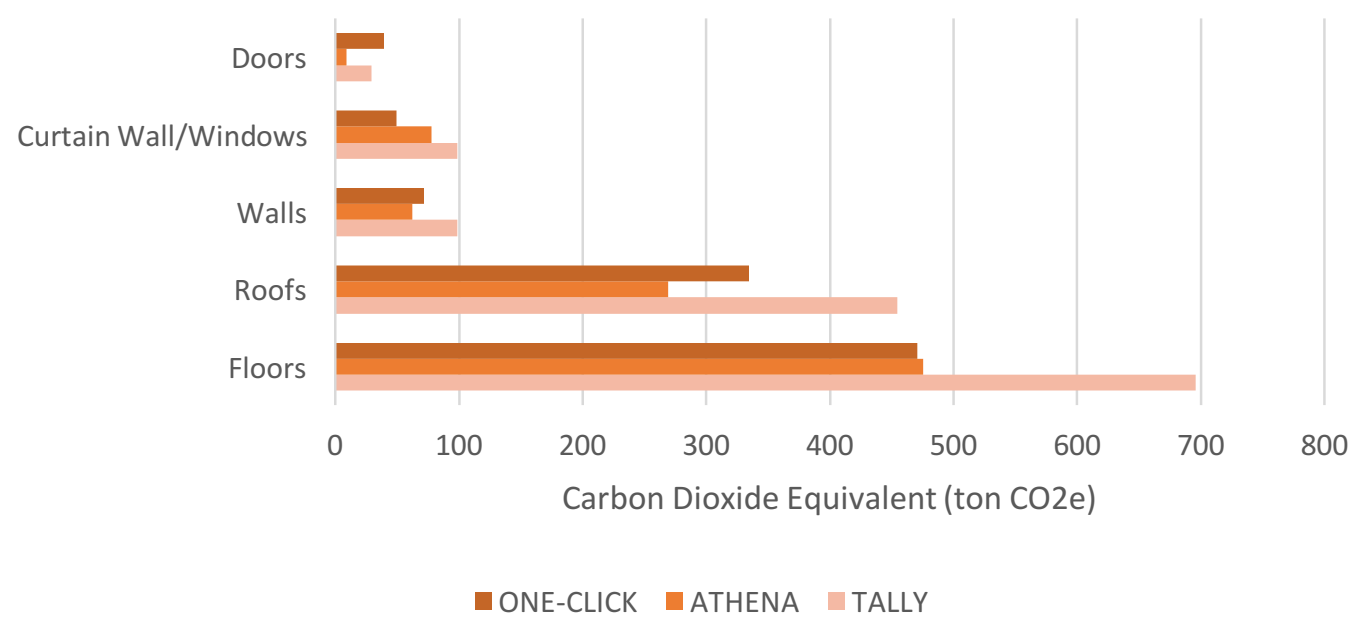

Figure 7: Comparison of the Three Life-Cycle Assessment Tools Total Carbon Dioxide Equivalents by Material Category 
The slab on grade concrete floors consists of air-entrained, $25 \mathrm{MPa}$ concrete with reinforcing. The floors are of varying thicknesses based on the existing floor height and sloped floor design. The volume of concrete was determined in accordance with construction drawings $A-100 A$ and A-100B Ground Floor Plans and A-002 Assemblies. The volume of concrete and mass of reinforcing was extracted from the Autodesk Revit file in order to ensure material take offs were identical among all models. While the volume of concrete is the same, the mass is different depending on the concrete composition and associated density selected.

The 4000 psi concrete selected in the Athena Impact Estimator outputs a carbon impact of $470,000 \mathrm{~kg} \mathrm{CO} 2$ eq for the $2,902,000 \mathrm{~kg}$ of concrete. Therefore, the emissions factor utilized by the Athena Impact Estimator is $0.16 \mathrm{~kg} \mathrm{CO} 2 \mathrm{eq} / \mathrm{kg}$ concrete. The air-entrained structural concrete selected in the Tally model outputs a carbon impact of $695,682 \mathrm{~kg} \mathrm{CO}_{2} \mathrm{eq}$ for the $2,509,113 \mathrm{~kg}$ concrete. Therefore, the emissions factor utilized by Tally is $0.28 \mathrm{~kg} \mathrm{CO}_{2} \mathrm{eq} / \mathrm{kg}$ concrete- nearly double that of the Athena Impact Estimator for the same volume of material. The results from the Athena Impact Estimator and One-Click LCA are similar, which can be confirmed and justified given that the concrete EPD used selected in One-Click LCA was conducted by Athena Sustainable Materials Institute. Mix design \#1, 25GU with air entrainment 0-14\% FA/SC has an emissions factor of $327.33 \mathrm{~kg} \mathrm{CO} 2 \mathrm{eq} / \mathrm{m}^{3}$ concrete (Canadian Ready Mix Concrete Associated, 2017). Tally's U.S. material database with an emissions factor nearly double that of the other tools report substantially different results from One-Click LCA and Athena Impact Estimator's similar Canadian values.

The rigid poly iso insulation specified on the Brickworks Kilns project is the greatest contributor of carbon in the roof assembly. Upon further investigation, it is uncovered that the life span of materials in each model is represented in the outputs differently. In the Tally model, the Polyisocyanurate (PIR) board has a lifespan of 30 years, meaning the material requires replacement once over the 60-year lifespan of the building. Tally encompasses the replacement of materials in accordance with the expected service life including the cradle-to-gate manufacturing of the replacement product. For this reason, the embodied carbon of poly iso is doubled. In the One-Click $L C A$, the poly iso foam board has the same life span of the building 
and has an emissions factor significantly lower than the Tally model of $2.08 \mathrm{~kg} \mathrm{CO}_{2} / \mathrm{kg}$ poly iso as opposed to $4.18 \mathrm{~kg} \mathrm{CO}_{2} / \mathrm{kg}$ poly iso.

\subsection{Results by Life-Cycle Phase}

Table 8 and Figure 8 summarize the life cycle assessment tool outputs by life cycle phase. Each tool classifies the outputs slightly differently, however all in the EN 15978 annotation format and nomenclature.

As noted in Table 8, phase A4 is not included in the Tally and One-Click LCA models, where the emissions due to construction are embedded in the Athena Impact Estimator back-end calculator, therefore results vary significantly and the scope of included phases are not consistent. As well, as noted above, phase B4 is handled in a very different manner model-to-model where Tally's embedded material life spans influence the material replacement emissions and material lifespans cannot be altered by the user, increasing both the product life phase and replacement phase. Additionally, the three models treat the end-of-life phase differently where Tally takes the "avoided burden" approach where the building receives credit for material recyclability, where Athena Impact Estimator and One-Click LCA consider end-of-life material recyclability to be the benefit of the recycled content buyer, so to not double count emissions savings.

Table 8: Summary of Life Cycle Assessment Tool Outputs by Phase in ton $\mathrm{CO}_{2}$ eq

\begin{tabular}{|l|r|r|r|}
\hline & Tally & Athena & One-Click \\
Product Life (A1-A3) & $\mathbf{1 1 0 2 . 3 8}$ & $\mathbf{7 3 2 . 4 1}$ & $\mathbf{7 2 3 . 4 8}$ \\
Raw Material Extraction (A1) & & & \\
Transportation (A2) & & 0.45 & \\
Manufacturing (A3) & & 731.95 & $\mathbf{4 8 . 3 8}$ \\
\hline Construction Process (A4-A5) & $\mathbf{1 7 . 9 7}$ & 26.56 & 0.00 \\
Construction Processes (A4) & 0.00 & 21.81 & 48.83 \\
Transportation (A5) & 17.97 & 0.00 & $\mathbf{8 , 6 4 9 . 6}$ \\
\hline Use (B1-B6) & $\mathbf{1 7 , 0 4 6 . 1 9}$ & $\mathbf{1 4 , 2 2 8 . 6 2}$ & 0.00 \\
Use (B1) & 0.00 & & 158.60 \\
Maintenance (B2) & & 76.61 & \\
Repair (B3) & 257.19 & & \\
Replacement (B4) & & &
\end{tabular}




\begin{tabular}{|l|r|r|r|} 
Operational Energy and Water (B6) & 16,789 & 14,152 & 8,491 \\
\hline End of Life (C1-C4) & $\mathbf{- 0 . 3 7}$ & $\mathbf{3 5 . 6 6}$ & \\
Deconstruction/Demolition (C1) & & 25.60 & \\
Transport (C2) & & 10.05 & 34.22 \\
Waste Processing (C3) & & & \\
Disposal (C4) & $\mathbf{1 8 , 1 6 6 . 1 7}$ & $\mathbf{1 5 , 0 4 4 . 4 5}$ & $\mathbf{9 , 4 5 6 . 1 6}$ \\
\hline TOTAL (ton CO2 eq)
\end{tabular}

Figure 8 is a visual representation of Table 8 , where given the scope of inclusions and exclusions considered for this research, the operational carbon over the lifespan of the building far surpasses the embodied carbon, where the operational carbon accounts for $92 \%$ of the Tally model, 94\% of the Athena Impact Estimator model and 90\% of the One-Click LCA model. This result suggests that the Brickworks Kilns adaptive reuse project benefits from material reuse, avoiding the environmental burden of new materials.

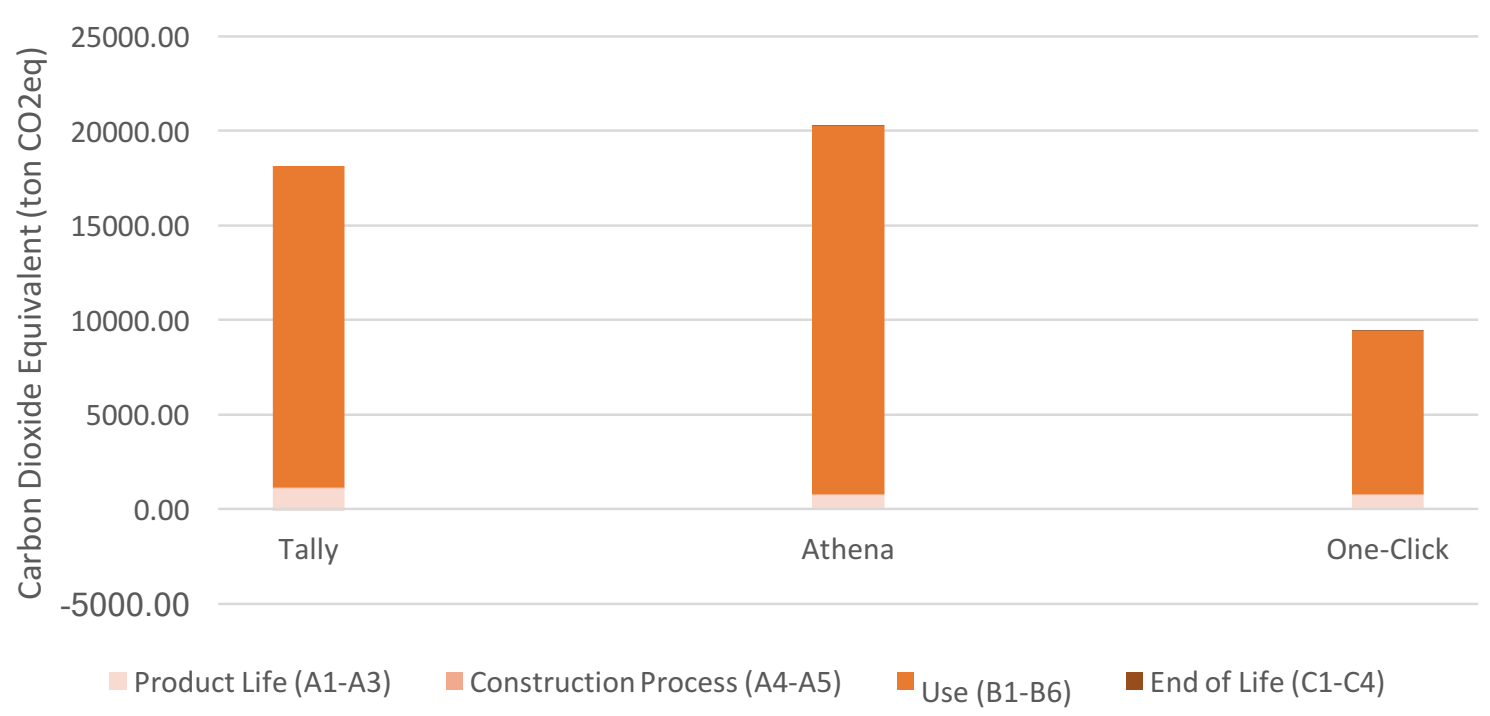

Figure 8: Comparison of the Three Life-Cycle Assessment Tools Total Carbon Dioxide Equivalents by Life-Cycle Phase

Figure 9 compares the building's embodied carbon, identical to Figure 8 without the operational phase (B6) showing the distribution of material embodied emissions over the life span of the building. In all cases, the product stage dominates where over $80 \%$ of the embodied emissions are accumulated during the raw material extraction and product manufacturing stage. 


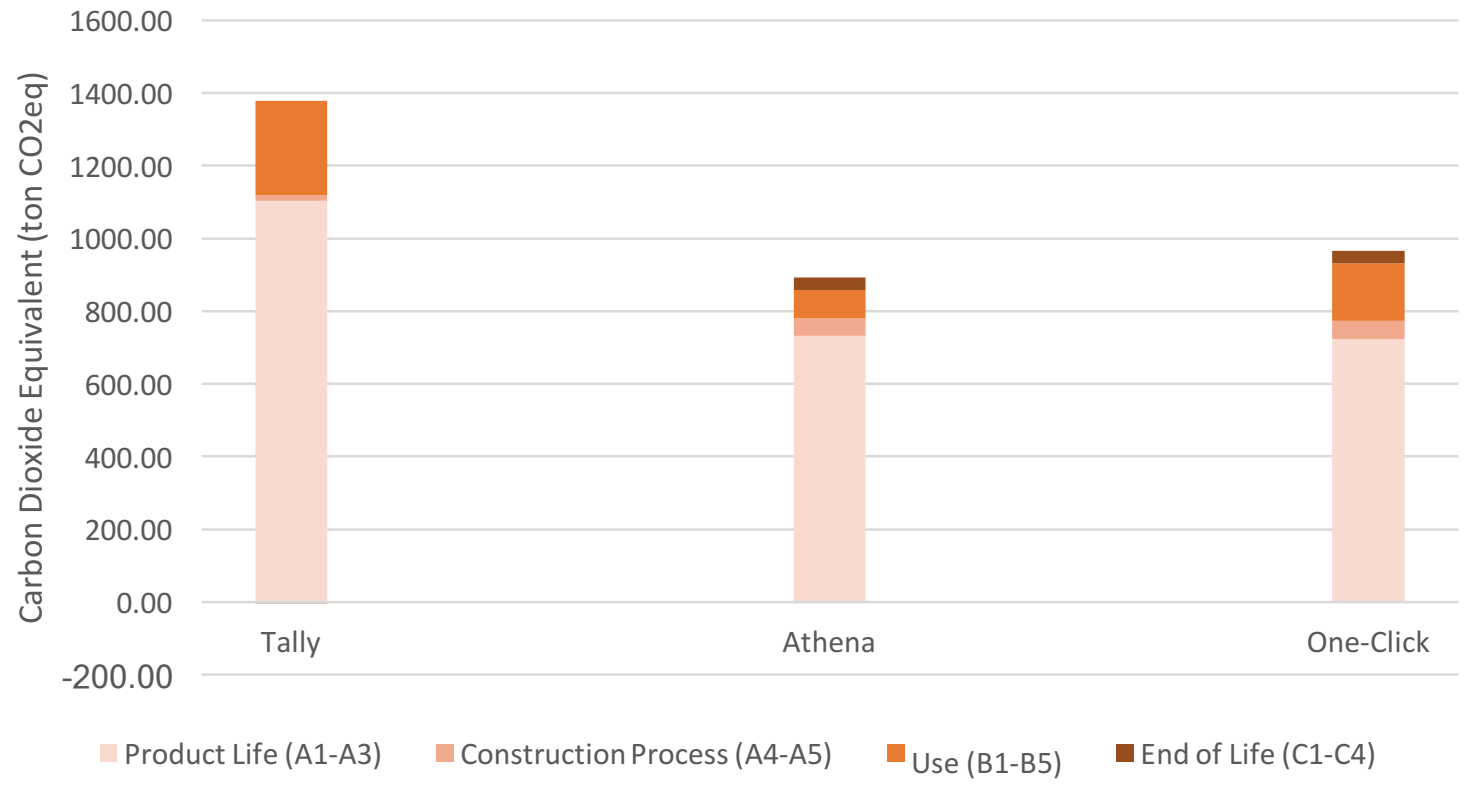

Figure 9: Comparison of the Three Life-Cycle Assessment Tools Total Carbon Dioxide Equivalents by Life-Cycle Phase (Excluding Operational Energy - B6)

Figure 10 and Figure 11 are the identical graphs to Figure 8 and Figure 9 however expressed in total primary energy demand in mega joules as opposed to carbon dioxide equivalents. When comparing Figure 8 and Figure 10, it can be concluded that the carbon emissions factor applied to One-Click LCA is substantially lower than those used in the other two programs, where OneClick LCA has the highest energy use but the lowest carbon equivalents. Alternatively, the energy demand and carbon equivalents of Tally and Athena Impact Estimator have a similar ratio when expressed in both metrics, where results vary in both metrics by under $10 \%$.

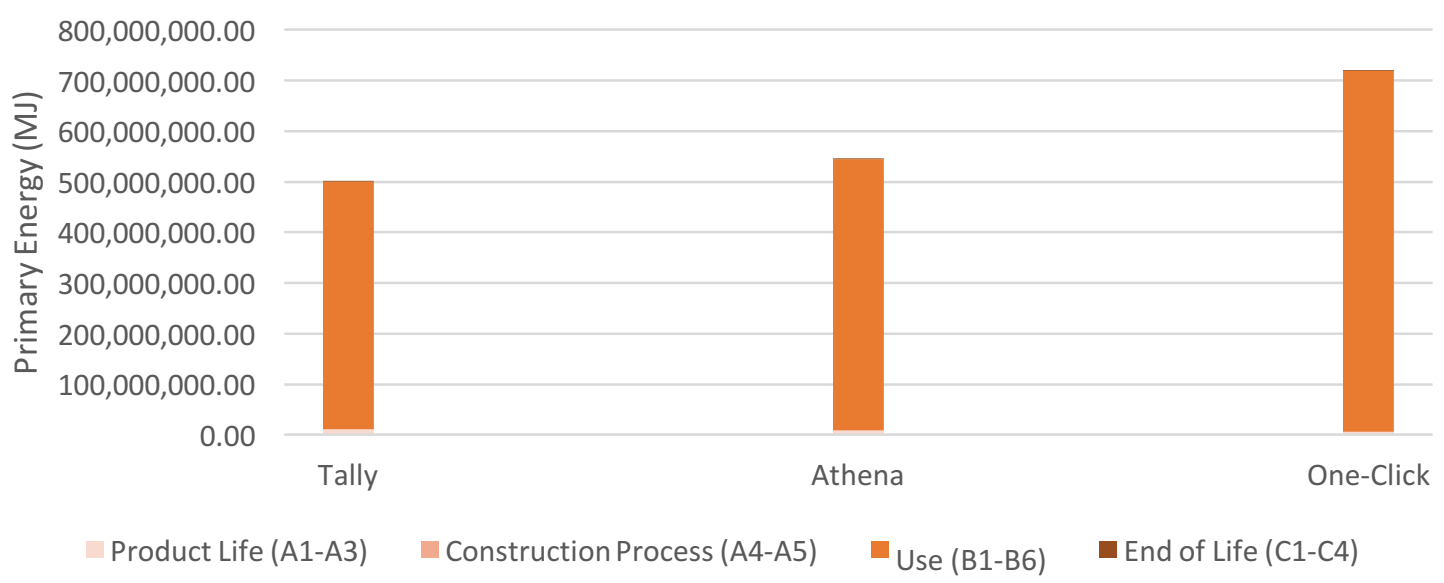

Figure 10: Comparison of the Three Life-Cycle Assessment Tools Total Primary Energy by Life-Cycle Phase 
Figure 11 further concludes that there is significant variability between the embodied emissions output of the three programs where when expressed in primary energy demand, Tally remains the highest emitter, while Athena Impact Estimator and One-Click LCA reverse. By graphing the life cycle phases in terms of total primary energy demand, it can be concluded that both the carbon conversion and the analysis used to determine the energy metrics are inconsistent.

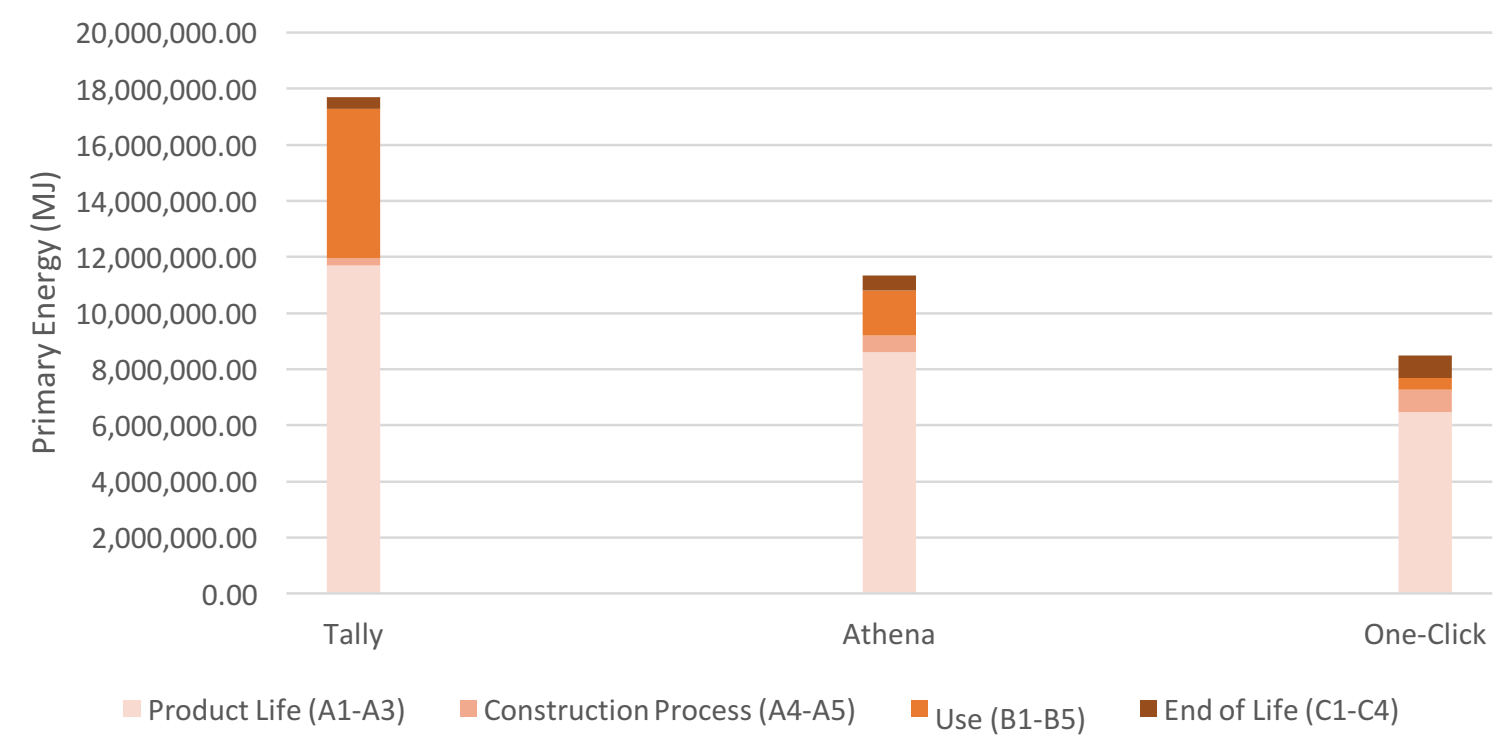

Figure 11: Comparison of the Three Life-Cycle Assessment Tools Total Primary Energy by Life-Cycle Phase (Excluding Operational Energy - B6)

\subsubsection{Product Life (A1-A3)}

One-Click $L C A$ extrapolates the product life phase data directly from the EPDs conducted by third party verifiers based on the area, volume or weight of material in the bill of materials. EPDs encompass the full product stage including raw material extraction (A1), intermediate transportation (A2) and manufacturing and assembly (A3). Similarly, Tally's reported product life values include phases A1-A3. Athena Impact Estimator reports product LCA based on the Athena LCI Database of generic material, not specific to a single manufacturer or product. Transportation estimations are regionally specific.

As discussed, Tally's US material database have significantly different emissions factors associated with each material, which is reflected in the 33\% increase in carbon emissions in the Product Life phase compared to Athena Impact Estimator and One-Click LCA. 


\subsubsection{Construction Process (A4-A5)}

While One-Click LCA does have the capability to calculate emissions from construction processes typically, the trial license does not include this phase and therefore outputs zero emissions. It is unknown whether One-Click LCA considered construction waste in the A4 calculation. Given the transportation distances inputted from manufacturer to site and the area, volume or weight of material, One-Click LCA applies the appropriate emissions factor based on an estimated number of vehicles and fuel type.

The Athena Impact Estimator model reports an estimated construction process emissions value based on the Athena Construction Emissions Database, an undisclosed database used in all Athena Impact Estimator modelling. The Athena Impact Estimator applies a construction waste factor to all material in the bill of materials, however whether the construction waste processing emissions are considered in the construction phase is undisclosed. Transportation distances applied based on regional data and are applied based on the nearest city in the Athena Impact Estimator database.

The on-site construction emissions in the Tally model is determined based on a single input of total energy used on site during construction. The value is required to be calculated external from the Tally program either as an estimated value or a reported sub-metered total. In the case of the Brickworks project, the energy consumed during construction is unknown, therefore the input is left blank and does not contribute to the analysis. Given the transportation distances inputted from manufacturer to site and the area, volume or eight of material, Tally applies a U.S. average emissions factor based on an estimated number of vehicles and fuel type.

\subsubsection{Use (B1-B6)}

One-Click LCA typically has material life spans the same as the building for all envelope and structural materials, and shorter life spans for interior and exterior finishes, windows and doors. The program assumes that envelope and structural materials cannot be simply removed and replaced without removing and replacing the surrounding materials. Alternatively, Tally has predetermined product lifespans that cannot be altered for all materials, assuming an internal 
component could be replaced without damaging surrounding materials. This method works in theory and is a more conservative report of the required replacement of materials, however not practical given how buildings are constructed and operated.

In the Tally model, maintenance and replacement considers the service life of each material, where the end of life emissions from the existing product are included, as well as the cradle-togate, transportation to site and construction process emissions of the replacement product, assuming the identical product is installed.

The Athena Impact Estimator does not indicate where the maintenance, repair, replacement and refurbishment outputs are gathered from. All three programs provide one all-encompassing value, rather than split into each life cycle phase (B2-B5).

\subsubsection{Operational Energy}

The operational electrical carbon emissions outputted from Tally uses the Canadian average electricity carbon emissions for final consumers, including transmission and distribution losses and electricity imports for neighboring countries as taking from the International Energy Agency statistics for the corresponding reference year of 2010. Given an inputted annual electricity usage of 1,010,000 kWh over the 60-year lifespan of the building and the total carbon emissions reported, the emissions factor is determined to be $0.28 \mathrm{~kg} \mathrm{CO}_{2} / \mathrm{kWh}$

Athena Impact Estimator's electrical emissions factor is regionally customized, where appropriate electricity grids are reflected in the emissions factor, according to the Athena Sustainable Materials Institute (Athena Sustainable Materials Institute, 2011). Given an inputted annual electricity usage of $1,010,000 \mathrm{kWh}$ over the 60 -year lifespan of the building and the total carbon emissions reported, the emissions factor is determined to be $0.32 \mathrm{~kg} \mathrm{CO}_{2} / \mathrm{kWh}$.

The operational electrical energy outputted from One-Click $L C A$ is determined using Statistics Canada 2015 data, and reflects the Ontario power grid according to Bionova Ltd. Given an inputted annual electricity usage of 1,010,000 kWh over the 60 -year lifespan of the building and the total carbon emissions reported, the emissions factor is determined to be $0.14 \mathrm{~kg} \mathrm{CO} / \mathrm{kWh}$. 
In relation to latest Environment Canada National Inventories from 2011 which reports an electricity grid emissions factor in Ontario of $0.11 \mathrm{~kg} \mathrm{CO} 2 \mathrm{eq} / \mathrm{kWh}$ (Environment Canada, 2011), the emissions reported from the three programs are significantly greater-more than double in the case of the Athena Impact Estimator. Figure 12 graphically demonstrated the differences in outputted operational energy carbon emissions from each program with reference to the Environment Canada Inventories Report emissions factor from 2011, totaling 6,606 ton $\mathrm{CO}_{2} \mathrm{eq}$ over the 60-year building operation period.

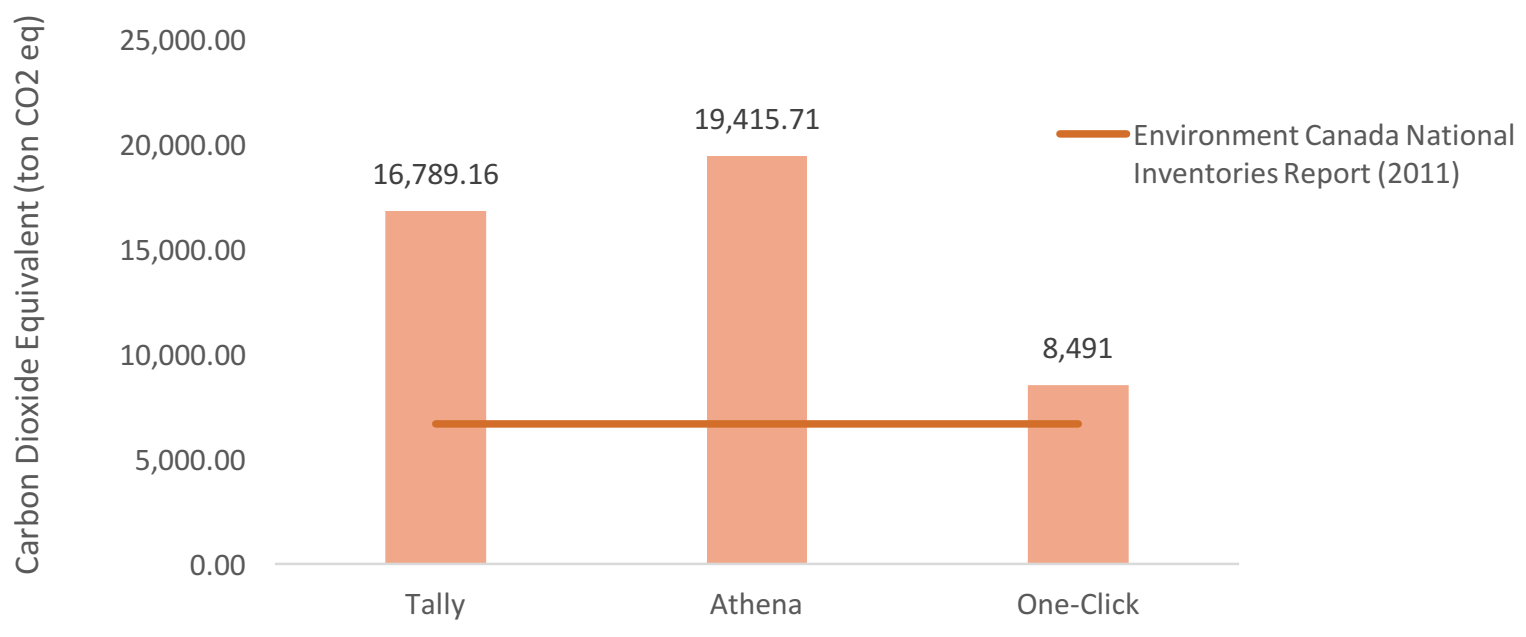

Figure 12: Comparison of Operational Energy (B6) Carbon Dioxide Emissions over the 60-Year Building Life Span

\subsubsection{End-of-Life (C1-C4)}

Tally's end-of-life reporting is based on average US construction and demolition waste treatment methods and rates including relevant material collection for recycling, incineration and landfilling rates. Recycling is modeled using an "avoided burden" approach where the burden of primary material production is allocated to the subsequent life cycle based on the quantity of recoverable material. For example, the aluminum sheet installed on site has a $95 \%$ recovery rate and 5\% landfilled. The brick installed has a 50\% recycling rate, 50\% landfilling. The cement bonded particle board is $100 \%$ disposed in landfill. The rates reported assume the incoming project respects the recycling potential of each material. The Brickworks Kilns project outputted a negative emission value in the end-of-life phase, implying that the emissions saved by product 
recyclability outweighs the emissions to deconstruct, demolish, transport and dispose of all materials on site. Transportation off-site is excluded in Tally modelling.

One-Click LCA determines the end-of-life emissions as specified on the EPD of each material based on the recycling potential of each material. Details such as waste and recycling facility efficiency, transportation distances and deconstruction processes and their associated emissions are undisclosed in One-Click LCA.

The Athena Impact Estimator calculates the end-of-life effects on the "producer pay" principle where credit is not given based on future reuse of recovered material on future projects as it assumes the future project attains the "savings" from selecting recycled or recovered materials, so to not double count the sequestration or emissions savings on both the current and future projects. The end-of-life emissions account for the environmental burden of demolishing the building and transporting material to landfill (Athena Sustainable Materials Institute, 2011).

\section{Discussion}

The three life cycle assessment tools were evaluated and compared to determine which program offers the most opportunity in the Canadian construction market to report accurate carbon accumulation over the life time of a building or infrastructure project. While each program offers a unique approach and reporting system to whole building life cycle assessment, no one tool is superior in all respects. Upon conducting three whole building life-cycle assessments on the case study building using the three tools in question, Table 9 qualitatively compares the three tools based on their geographical applicability to Canadian projects, program user experience, material databases quality, scope inclusions and exclusions, and program restrictions using the Harvey Balls method. 


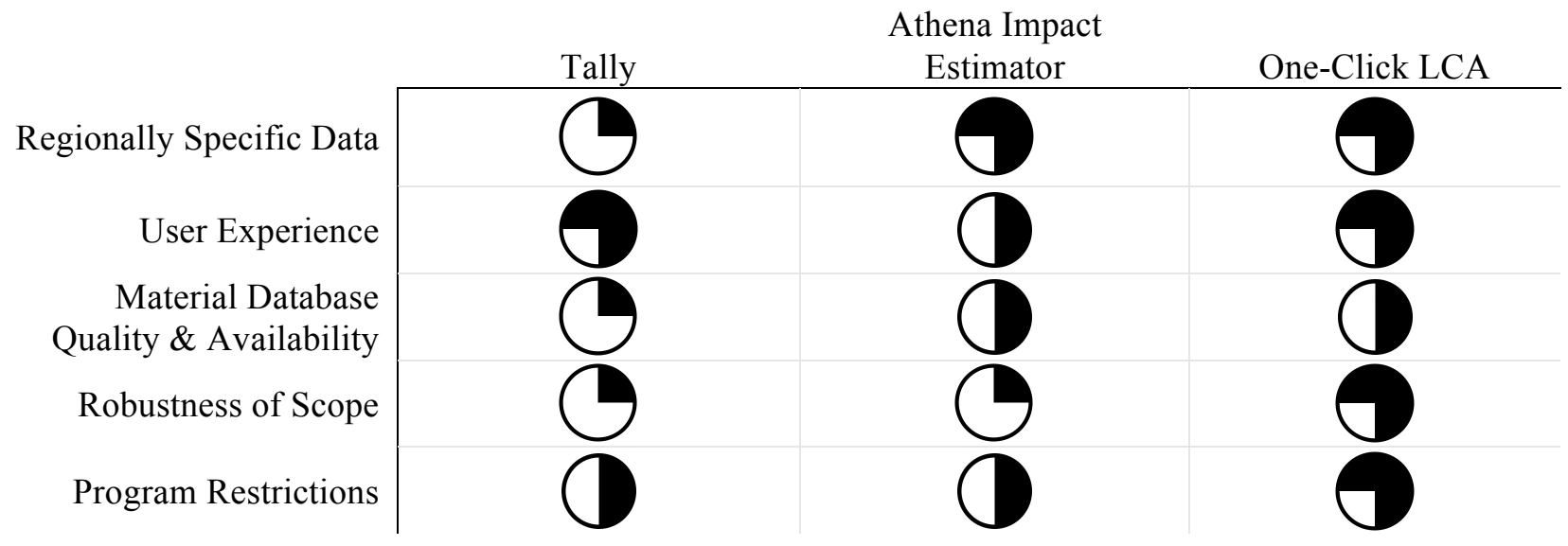

\subsection{Regionally Specific Data}

Regional specificity has a significant impact on carbon emissions reporting at all life cycle phases, as seen in the high variability in the case study results presented. The Tally databases are predominantly from the U.S., meaning all back-end calculations and assumptions are based on American inputs and averages. Material and product life cycle assessments are based on American manufacturing plants, auto-populated transportation distances and methods are based off American averages and end-of-life calculations are based off American methods. Additionally, the program only includes one Canadian electricity grid mix option, meaning the grid mix reported generalizes the entirely of Canada rather than the cleaner Ontario grid.

The Athena Impact Estimator computes back-end calculations based on the project location's regional averages and assumptions of the closest city in the database. All major Canadian cities are listed, as well as some major U.S. cities. This data affects the back-end calculations of transportation distances and methods, electricity grid mixes and associated emissions factors and, end-of-life scenarios. Some issues arise from this method however, as should a project be located a significant distance away from the nearest city, transportation emissions are expected to be far greater than the averages reported by the Athena Impact Estimator. The North American material database and associated LCA data reflects generic products available in Canada, meaning major greenhouse gas emitting materials such as concrete and steel are represented accurately. 
One-Click LCA utilizes specific product EPDs, meaning the emissions associated with specific materials are specific to the region in which they are produced and have been third-party verified confirming their accuracy. This method is superior when products with EPDs are specified, however does not have the same level of accuracy when substituted for similar products. Issues with an EPD-only database are discussed in detail below in section 7.2.3. The electricity grid mix selection in the One-Click LCA database is specific by Canadian provinces and values are taken from 2015 Statistics Canada data.

\subsection{User Experience}

User experience has significant implications on whether programs are adopted into industry practice and widely used across sectors. Input simplicity and consistency, transparency of program capabilities and output clarity ensure users are able to accurately and confidently report a project's emissions over its life time.

Being integrated into AutoDesk Revit, Tally's modelling interface offers an exceptional user experience where material take-offs, quantities and weights are auto-generated based on the Revit model and selected materials' associated densities. One disadvantageous feature in Tally is the on-site construction impact input requirements, where the program accepts a single input for electricity, heating and water rather than being a program estimation based on material quantities and building typology like the other two programs. While this method is more accurate for postconstruction reporting if the site is sub-metered during construction, it is less valuable during the design phase without a baseline or auto-generated input. Tally generates a thorough life cycle assessment report for every design iteration that identifies where all back-end calculation values are extracted from and separates outputs into various categories such as life cycle phase, building component and by specific material.

The Athena Impact Estimator bill of materials method poses some difficulty to users as the program only accepts specific units of measure based on material, meaning the input requirements are more intensive with a larger chance of error. For example, the weight of steel 
framing, the volume of paint on walls and the thickness of insulation must be inputted in $25 \mathrm{~mm}$ steps. The Athena Impact Estimator has limited transparency of where back-end calculation values are extracted from, the methodology undertaken and the date last updated. As well, when performing a whole building life cycle assessment in the Athena Impact Estimator, results are exported in only two ways; by life cycle phase and by building component. The program does not allow individual material analysis, or life cycle impacts by material. In order to gather this data, a separate model must be created that analyses one material at a time.

Similar to the Athena Impact Estimator, the One-Click LCA model is generated from a bill of materials which can be either uploaded as an excel file, inputted manually or generated directly from AutoDesk Revit. The same challenges occur with material take-offs where the bill of materials exported from the AutoDesk Revit file is by volume rather than weight, meaning all steel quantities needed to be converted into weight to be inputted into One-Click LCA. Back-end calculation data sources are not readily available and do not describe the scope of inclusions and exclusions of each life cycle stage. Results can be exported by life cycle phase, building component and individual material, making data analysis straight forward and extensive.

\subsection{Material Database Quality and Availability}

As discussed, the U.S. material database embedded in Tally is populated using the GaBi LCA database. While the LCI of the generic materials is similar across borders, the LCIA varies significantly based on manufacturers, plant efficiency, raw material extraction methods, interim transportation distances and average recycled content of materials.

The Athena Impact Estimator material database has a limited selection and variability of materials, where the program inputs individual materials rather than pre-assembled materials such as doors, door hardware and stud wall systems. As well, non-standard concrete mix designs are not captured- the program only categorizes concrete by their strength, no additional properties such as air-entrainment, mix design number or percent recycled content. The database has limited glazing selection, innovative insulations or membranes, and mechanical and electrical equipment or conduit. 
While One-Click LCA's EPD driven database is set up to offer an extensive material database covering all building components, the usefulness of the program relies on industry adoption of EPDs by product manufacturers. BioNova Ltd. does not perform and populate the product LCA data like the other programs- it only inputs data from other publicly available information from third party verifiers. In the current version of One-Click $L C A$, the database has some major holes and missing information for example the lack of air barrier systems. In order for One-Click LCA to be used to its full potential, project specifications must only specify product that have EPDs. Until EPDs are more widely adopted by manufacturers, One-Click LCA's EPD driven database and reported whole building life cycle carbon emissions do not reflect the true as-built condition.

\subsection{Robustness of Scope}

Each life cycle assessment tools follow the ISO 14040 and 14044 principle and framework for LCA accounting, however the scope of included emissions vary program by program. Table 10 compares the building component modelling capabilities of each LCA tool. Athena Impact Estimator is predominantly used to model structure and envelope materials with limited ability to model all building components including mechanical equipment, piping and finishes. Tally does not support mechanical and electrical equipment or site work and landscaping. One-Click LCA is set up to support all material types, building systems and surrounding site work or landscaping, however limited to materials which have EPDs.

Table 10: Life Cycle Assessment Tool Modelling Capabilities

\begin{tabular}{|c|c|c|c|}
\hline & Tally & $\begin{array}{c}\text { Athena Impact } \\
\text { Estimator }\end{array}$ & One-Click LCA \\
\hline Load Bearing Members & Yes & Yes & Yes \\
\hline Stairs & Yes & By component & Yes \\
\hline Doors & Yes & By component & Yes \\
\hline Site Work and Landscaping & No & No & Yes \\
\hline Mechanical & No & No & Yes \\
\hline Electrical & No & No & Yes \\
\hline Sealants, Primers, Coatings & Yes & Limited & Yes \\
\hline Nuts, bolts, Screws & Yes & Yes & Yes \\
\hline Finishes (Paint, Tile) & Yes & Limited & Yes \\
\hline
\end{tabular}




\subsection{Program Restrictions}

The Athena Impact Estimator is a free downloadable program that can be performed by industry professionals of all training levels if provided a detailed bill of materials from a project design team. Minimal additional training is required to operate the program. Tally has an annual free of \$695 US per floating license and requires a high skill level in AutoDesk Revit to operate and navigate fluently. One-Click $L C A$ has an annual fee of $\$ 1,500$ US per floating license, but can be operated by professionals of all skill levels if provided a detailed bill of materials from a project design team. One-Click $L C A$ also provides thorough training to all license holders to ensure consistent user understanding and training. 


\section{Conclusions}

The conducted research project seeks to examine and compare three life cycle assessment tools; Athena Impact Estimator, Tally and One-Click LCA to relate the input variability to the program outputs of the three programs. By conducting three whole building life-cycle assessments using a case study building's identical bill of materials, the research seeks to understand the applicability and strengths of one program over another and answer the presented research questions.

The research confirmed that the three programs output significantly different results given their variability of allowable program inputs, and back-end calculations and assumptions where the outputted whole building life cycle carbon equivalents of One-Click LCA is less than half than of Tally. However, the ratio of embodied emissions to operational emissions is similar across all three programs where the embodied emissions account for less than $10 \%$ of the total, and the material production stage account for over $80 \%$ of the embodied emissions. When compared to the total primary energy, it can be further concluded that not only are the carbon emissions factors variable, but the method of calculating the total energy from one programs to another varies as well.

Given that each of the three programs apply different back-end calculation LCI and LCIA methods that are not streamlined across the reporting process, the programs cannot be simply compared side-by-side. Better transparency, in particular in One-Click LCA and Athena Impact Estimator would greatly improve the ability to determine the accuracy of one program over another. Life cycle assessment tool generated "black-box" back-end calculations are approached with caution. While this may be beneficial from an industry user perspective by simplifying and outputting results quickly, this is disadvantageous to research personnel, as it takes away from the value of understanding and uncovering environmental "hot spots" through life cycle assessment interpretation.

Given the limitations placed on the Brickworks Kilns project to date including missing EPDs and vehicle transportation methods and distances, a high amount of uncertainty and assumptions 
were made to conduct the life cycle assessments, adding additional variability in results. In order to make the results more accurate and representative of the true works on site at the Brickworks Kilns projects, it is recommended to complete a whole building life cycle assessment upon completion of the project when all EPDs have been submitted and changes finalized. As well, for the purpose of this research and to simplify the project model, the Cupolex plastic air-voids in the concrete were not modelled. In order to accurately model the true material volumes on the Brickworks Kilns project, it is recommended to model the true material volume, or complete a volume to mass ratio and estimate the true mass of concrete on the site.

The research conducted compliments the current research and understand of whole building life cycle assessment tool comparisons where as noted in the research conducted by Al-Ghamdi \& Bilec, the high variability it inputs has a significant effect on the outputted results, creating inaccuracy and inconsistency among reporting. As whole building life cycle assessment becomes more widely used in industry, better accuracy and transparency is required in order for designers to confidently market and report carbon neutrality in buildings.

\subsection{Research Questions}

\section{What are the major similarities and differences between three readily available life-cycle assessment tools for Canadian construction projects?}

The three whole building life cycle assessment tools analyzed perform cradle-to-grave assessments following the ISO 14040 and 14044 standard framework. The three programs calculate differing impact categories, but all have the capability of calculating greenhouse gas emissions in mass of equivalent carbon dioxide.

The three programs execute the life cycle assessment in significantly different ways influencing the outputted results. Different material databases, associated emissions factors, input variability and back end calculations effectively means side-by-side comparisons cannot be made.

Additionally, the program reporting formats vary, therefore many of the results cannot be simply exported from the three programs and compared. 
1a. How much input flexibility is inherent in three readily available life-cycle assessment tools and identify the effect in output variability and accuracy?

The three programs offer different input flexibility having a significant effect on output variability and program accuracy. Depending on the level of detail known about the building under investigation, program selection will influence the output accuracy. In cases where the project is in the design phase where materials have not been specified, transportation methods and distances unknown and construction methods not determined, a simplified and generic model is favorable. To date, whole building life cycle assessment is used as a decision-making tool- selecting one material over another and making a decision whether to refurbish or build new. However, as industry requests accuracy in carbon reporting to achieve carbon reduction target and carbon neutral projects, accurate modelling that is accessible to industry is required.

1b. Which programs or strategies offer the most effective carbon accounting mechanism for the Canadian construction market?

In most respects, One-Click $L C A$ proves to be the life cycle assessment tool that addresses the Ontario Governments' call for action to create a consistent and accurate carbon accounting tool that is applicable to all new and existing building and infrastructure projects. One-Click LCA inputs regionally specific emissions factors, permits high flexibility in inputs, is straight forward for users and, has a committed, international team who are responsive and are consistently update and upgrading the program. On projects like the Brickworks Kilns project, One-Click $L C A$ is a superior life cycle assessment tool as it reflects the true products and materials installed on site because EPDs are enforced for all materials installed on site. Until EPDs are required and the supply chain is cleaned up such that transportation distances are known and required to be reported by sub trades, or when generic materials are added to the database, One-Click LCA does not hold much value on Canadian projects. On projects where EPDs are not enforced, or the projects is in the design phase where products are yet to be determined and project details are not finalized, the Athena Impact Estimator is preferred as it uses a generic material database and estimates details that are typically unknown during the design phase. As determined through this 
research, Tally does not prove to be an ideal life cycle assessment tool to be used in Canada until the material database is updated and emissions factors are regionally specific, as seen by the skewed results throughout.

\subsection{Future Research}

In completing this research, a number of future research areas have been identified that would strengthens the body of knowledge around whole building life cycle assessment. One major area is to delve further into how emissions are calculated in the construction phase in particular to better define a method to account for emissions for a specific project, rather than the current estimation method based on material quantities only. A framework or methodology is needed to specify machinery inventory and quantities, and temporary materials needed that is specific to the building. The framework should consider building typology and size, construction duration, location and site accessibility. The research conducted essentially ignores construction emissions as Tally and One-Click LCA do not auto-populate the emissions and therefore cannot be simply estimated. A better understanding of the percent emissions due to the construction phase would be valuable information to determine whether extensive research and detail is needed, or if the percent emissions is negligible.

In addition, extending the research to look at a broader range of projects including new builds and other refurbishment projects would further validate the research conclusions and determine whether results are consistent between a new build project and a refurbishment project. A new build project would also offer a different perspective in understanding the percent embodied carbon to operational carbon of a new build compared to a refurbishment and the differences in each program's resulting outputs. 


\section{References}

Al-Ghamdi, S., \& Bilec, M. (2017). Green Building Rating Systems and Whole-Building Life Cycle Assessment: Comparative Study of the Existing Assessment Tools. Pittsburgh: American Society of Civil Engineers.

Amiri, A., Caddock, P., \& Whitehead, M. (2013, 10 01). Accounting for the greenhouse gas emissions of construction: a UK case study. ice Proceedings, 166(CE2).

Athena Sustainable Materials Institute. (2011). Life Cycle Assessment of UBC Biological Sciences Complex Renew Project. UBC Project Services.

Biswas, K., Shrestha, S., Bhandari, M., \& Desjarlais, A. (2015). Insulation materials for commercial buildings in North America: An assessment of lifetime energy and environmental impacts. Oak Ridge National Laboratory. Oak Ridge: Energy and Buildings.

Canadian Green Building Council. (2017). Zero Carbon Building Standard. Canadian Green Building Council.

Canadian Ready Mix Concrete Associated. (2017). CRMCA Member Industry-Wide EPD for Canadian Ready-Mixed Concrete. Mississauga: NSF Certified Environmental Product Declaration.

Carruthers, H., \& Casavant, T. (2013, June). What is a "Carbon Neutral” Building? Light House Sustainable Building Centre Society.

De Wolf, C., Pomponi, F., \& Monc, A. (2017). Measuring embodied carbon dioxide equivalent of buildings: A. Energy and Buildings.

Environment Canada. (2011). Environment Canada National Inventories.

ERA Architects Inc. (2016). Evergreen Brickworks Building 16 Heritage Impact Assessment.

Evergreen. (2017). Kiln Building Redevelopment. Retrieved from https://www.evergreen.ca/getinvolved/evergreen-brick-works/visitor-info/kiln-building-redevelopment/

Gan, V., Cheng, J., \& Lo, I. (2016). Developing a CO2-e accounting method for quantification and analysis. Journal of Cleaner Production. Retrieved from Developing a CO2-e accounting method for quantification and analysis: http://ac.elscdn.com.ezproxy.lib.ryerson.ca/S0959652616314676/1-s2.0-S0959652616314676main.pdf?_tid=def0bbe0-88fe-11e7-82bb-

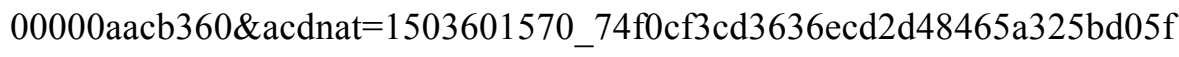

Government of Canada. (2015, 12 10). Environment and Climate Change Canada. Retrieved from Sulphur hexafluoride (SF6): https://www.ec.gc.ca/toxiques- 
toxics/Default.asp?lang=En\&n=98E80CC6-1\&xml=F8C4713B-DB7D-491D-8913-

0088E40C06C7

Government of Canada. (2016, 06 28). Environment and Climate Change Canada. Retrieved from

Perfluorocarbons (PFCs): https://www.ec.gc.ca/toxiques-

toxics/Default.asp?lang=En\&n=AA329670-1

Government of Canada. (2017, 04 13). Drivers and Impacts of Greenhouse Gas Emissions. Retrieved from Environment and Climate Change Canada: https://www.ec.gc.ca/indicateursindicators/default.asp?lang=En\&n=D4C4DBAB-1

Government of Canada. (2017, 03 16). Environment and Climate Change Canada. Retrieved from Global Warming Potentials: https://www.ec.gc.ca/ges-ghg/default.asp?lang=En\&n=cad07259-1

Government of Canada. (2017, 04 17). Environment and Climate Change Canada. Retrieved from Greenhouse Gas Emissions by Province and Territory: https://www.ec.gc.ca/indicateursindicators/default.asp?lang $=\mathrm{en} \& \mathrm{n}=18 \mathrm{~F} 3 \mathrm{BB} 9 \mathrm{C}-1$

Government of Canada. (2017, 03 16). Environment and Climate Change Canada. Retrieved from Global Warming Potentials: https://www.ec.gc.ca/ges-ghg/default.asp?lang=En\&n=CAD07259-1

Government of Ontario. (2016). Ontario's Five Year Climate Change Action Plan.

Haapio, A., \& Viitaniemi, P. (2008). A Critical Revie of Building Environmental Assessment Tools. Environmental Impact Assessment Review.

Hardy, J., \& Owens, V. (2013, 12). Light House. Retrieved from Life Cycle Analysis and Environmental Product Declarations: North American Market Analysis: http://www.sustainablebuildingcentre.com/wp-content/uploads/2013/12/Dec-2013_LCA-EPDwhite-paper.pdf

Herrmann, I., \& Moltesen, A. (2014). Does it matter which Life Cycle Assessment (LCA) tool you choose? A comparative assessment of SimaPro and GaBi. Elsevier.

Johnson, A., Jowitt, P., Grenfell, R., \& Moir, S. (2012). A protocol for carbon emissions accounting in infrastructure decisions. Retrieved from Proceedings of the Institution of Civil Engineers, vol. 165, (2), pp. 89-95: https://search-proquestcom.ezproxy.lib.ryerson.ca/docview/1019050645?accountid=13631

Kim, K.-H. (2011). A comparative life cycle assessment of a transparent composite fac, ade system and a glass curtain wall system. University of North Carolina. Charlotte: Energy and Buildings.

Kylili, A., Ilic, M., \& Fokaides, P. (2017). Whole-building Life Cycle Assessment (LCA) of a passive house of the sub-tropical climatic zone. Resources, Conservation and Recycling.

Paleari, M., Lavagna, M., \& Campioli, A. (2016). The assessment of the relevance of building components and life phases for the environmental profile of nearly zero-energy buildings: life 
cycle assessment of a multifamily building in Italy. Building Components and Buildings. Springer.

Pow Chew Wong, J., \& Iyer-Raniga, U. (2011). Evaluation of whole life cycle assessment for heritage buildings in Australia. RMIT University. Melbourne: Building and Environment.

Robertson, A., Lam, F., \& Cole, R. (2012). A Comparative Cradle-to-Gate Life Cycle Assessment of MidRise Office Building Construction Alternatives: Laminated Timber or Reinforced Concrete. University of British Columbia, Vancouver.

Statistics Canada. (2016, 10 07). Construction. Retrieved from http://www.statcan.gc.ca/pub/11-402$\mathrm{x} / 2011000 /$ chap/construction/construction-eng.htm

The American Institute of Architects. (2017). Hughes Warehouse Adaptive Reuse. Retrieved from The American Institute of Architects: http://www.aiatopten.org/node/460

ThinkStep Gabi. (2017, 01). Gabi Modelling Principles. Retrieved from Documentation for Truck Transport Processes: http://www.gabisoftware.com/fileadmin/GaBi_Databases/Documentation_GaBi_Transport_Processes_Duty_Vehi cles_2016_unchanged_for_2017.pdf

U.S. Department of Energy. (2015). A Common Definition of Net-Zero Energy Buildings. National Institute of Building Science.

United Nations Environment. (2016, 09). Sustainable Buildings and Construction Programme. Retrieved from http://www.unep.org/10yfp/programmes/sustainable-buildings-and-construction-programme

United States Environmental Protection Agency. (2016, 12 30). Significant New Alternatives Policy $(S N A P)$. Retrieved from Reducing Hydrofluorocarbon (HFC) Use and Emissions in the Federal Sector: https://www.epa.gov/snap/reducing-hydrofluorocarbon-hfc-use-and-emissions-federalsector

United States Environmental Protection Agency. (2017, 04 14). Greenhouse Gas Emissions. Retrieved from Overview of Greenhouse Gases: https://www.epa.gov/ghgemissions/overview-greenhousegases

World Bank Group. (2017). 2016-2017 Carbon Pricing Leadership Report. Retrieved from http://pubdocs.worldbank.org/en/183521492529539277/WBG-CPLC-2017-Leadership-ReportDIGITAL-Single-Pages.pdf

Xiao, A. A. (2017, January 4). Estimation and Minimization of Embodied Carbon of Buildings: A Review. MDPI: Buildings. 


\section{Appendix}

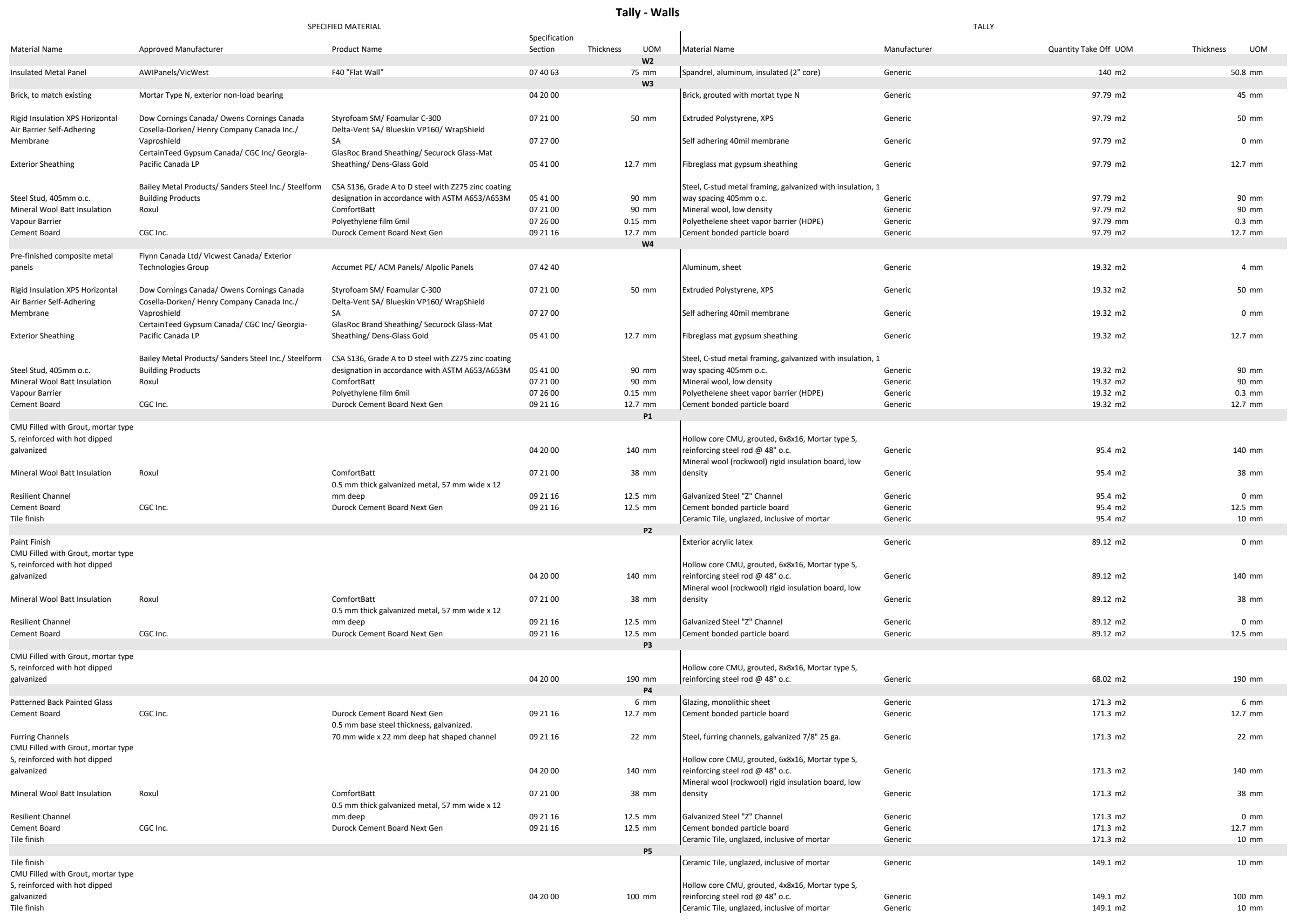




\section{Tally - Curtain Wall/Windows}

SPECIFIED MATERIAL

Material Name

Approved Manufacturer Product Name

AGC Flat Glass/ Cardinal Glass

Industries/ Guardian

Industries/ Oldcastle Glass

Inc/ PPG Industries Ltd./

Viracon Inc.

Type 2: TGL

AGC Flat Glass/Cardinal Glass

Industries/Guardian

Industries/ Oldcastle Glass

Inc/ PPG Industries Ltd./

Viracon Inc.

Double Pane, Float Glass,

Type 1: FGL

AGC Flat Glass/ Cardinal Glass

Industries/ Guardian

Industries/ Oldcastle Glass

Inc/ PPG Industries Ltd./ Double Pane, Tempered,

Type 2: TGL

Viracon Inc.

low-e coating
Specification Section Thickness

CW1

088000

CW3

$25 \mathrm{~mm}$

Windows

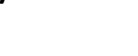

UOM

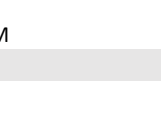

TALLY
Manufact Quantity

$\begin{array}{lll} & \text { Manufact } & \text { Quantity } \\ \text { Material Name } & \text { urer } & \text { Take Off UOM }\end{array}$

Thickness UOM

Glazing, double pane

$\mathrm{GU}, 2$ layers of $4 \mathrm{~mm}$

thick glass, air filled,

low-e

Generic $\quad 383.815 \mathrm{~m} 2$

\section{Glazing, double pane}

IGU, 2 layers of $4 \mathrm{~mm}$

thick glass, air filled

low-e

Generic

$140.085 \mathrm{~m} 2$

Glazing, double pane

IGU, 2 layers of $4 \mathrm{~mm}$

thick glass, air filled,

low-e

Generic $\quad 18.061 \mathrm{~m} 2$ 


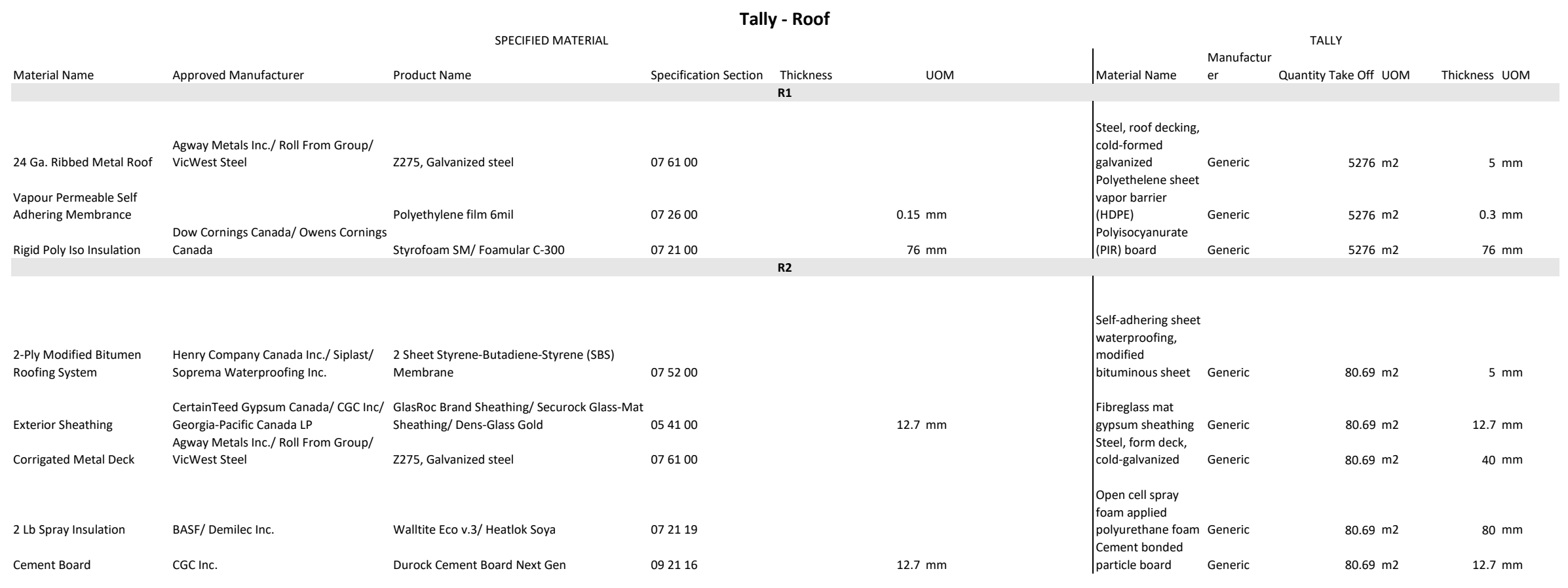




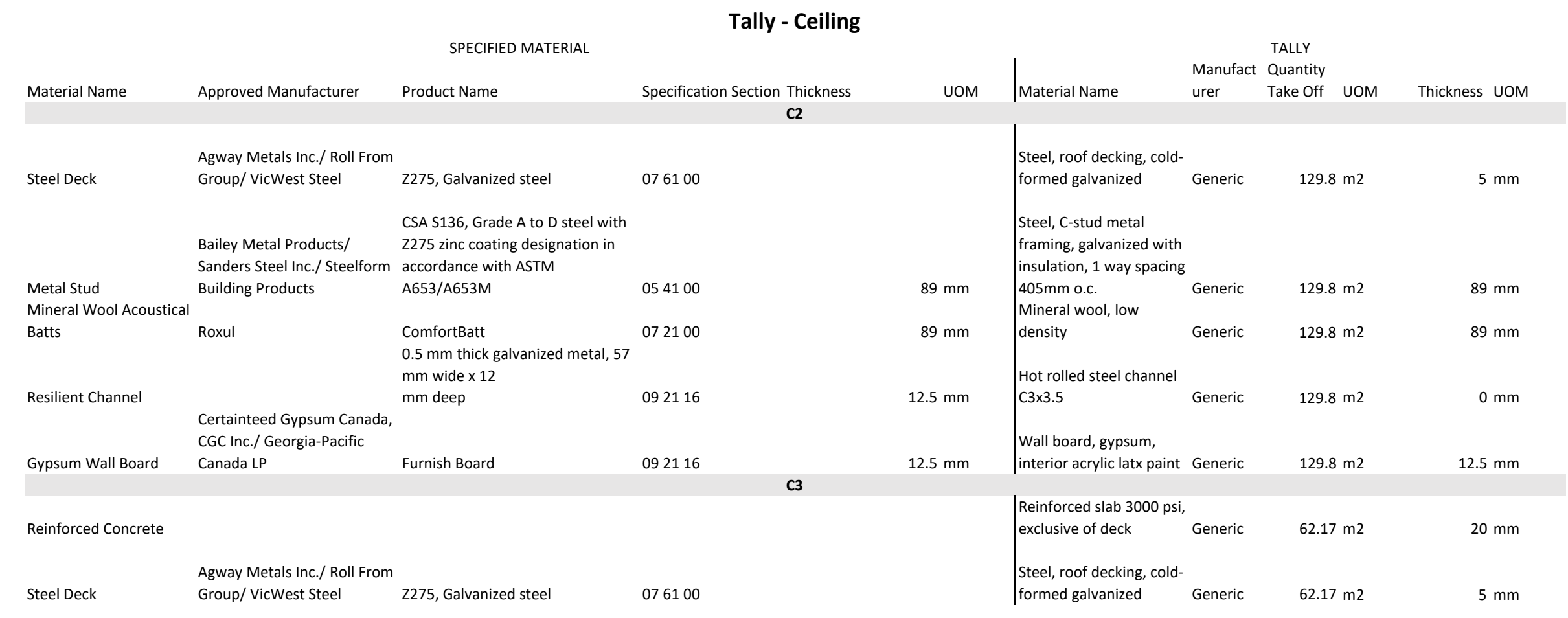




\begin{tabular}{|c|c|c|c|c|c|c|c|c|c|}
\hline Material Name & Approved Manufacturer & Product Name & Specification Section & Thickness & UOM & Material Name & Manufacturer & Quantity Take Off UOM & Thickness UOM \\
\hline & & & & & & & & & \\
\hline $\begin{array}{l}\text { Polished Concrete with radiant } \\
\text { and wire mesh }\end{array}$ & & & & & 75 mm & $\begin{array}{l}\text { Structural, } \\
\text { unreinforced, } \\
\text { 3000psi/20MPa }\end{array}$ & Generic & $2407.5 \mathrm{~m} 2$ & $75 \mathrm{~mm}$ \\
\hline Insulated Concrete (R10) & Foamcrete & Dufferin Concrete & & & 127 mm & $\begin{array}{l}\text { Air-Entrained } \\
\text { Structural concrete, } \\
\text { unreinforced }\end{array}$ & Generic & $2407.5 \mathrm{~m} 2$ & $127 \mathrm{~mm}$ \\
\hline Raised Structural Cavity floor & Cupolex & $\begin{array}{l}\text { Cupolex Modular Vaulted Sub- } \\
\text { slab Forms, } 25 \mathrm{Mpa}\end{array}$ & & Varies & & $\mid \begin{array}{l}\text { Air-Entrained } \\
\text { Structural concrete, } \\
\text { unreinforced }\end{array}$ & Generic & $2407.5 \mathrm{~m} 2$ & $250 \mathrm{~mm}$ \\
\hline & & & & & & & & & \\
\hline $\begin{array}{l}\text { Polished Concrete with radiant } \\
\text { and wire mesh }\end{array}$ & & & & & 75 mm & $\begin{array}{l}\text { Structural, } \\
\text { unreinforced, } \\
\text { 3000psi/20MPa }\end{array}$ & Generic & $208.07 \mathrm{~m} 2$ & $75 \mathrm{~mm}$ \\
\hline Insulated Concrete (R10) & Foamcrete & Dufferin Concrete & & Varies & & $\mid \begin{array}{l}\text { Air-Entrained } \\
\text { Structural concrete, } \\
\text { unreinforced }\end{array}$ & Generic & $208.07 \mathrm{~m} 2$ & $375 \mathrm{~mm}$ \\
\hline & & & & & & & & & \\
\hline Concrete Finish & & & & & & $\begin{array}{l}\text { Structural, } \\
\text { unreinforced, } \\
\text { 3000psi/20MPa }\end{array}$ & Generic & $86.07 \mathrm{~m} 2$ & $89 \mathrm{~mm}$ \\
\hline Reinforced Concrete on Steel & & & & & & Steel, cold formed & & & \\
\hline Deck & & & & & & |galvanized deck & Generic & $86.07 \mathrm{~m} 2$ & $0.76 \mathrm{~mm}$ \\
\hline & & & & & & & & & \\
\hline Reinforced Concrete Slab & & & & & $150 \mathrm{~mm}$ & \begin{tabular}{|l} 
Cast-in-place \\
concrete, slab on \\
grade with \\
reinforcing steel \\
|inclusive
\end{tabular} & Generic & $75.09 \mathrm{~m} 2$ & $150 \mathrm{~mm}$ \\
\hline
\end{tabular}


SPECIFIED MATERIAL

Material Name

Approved Manufacturer

Fleming Doors Products/ Daybar

Frame: Aluminum, finish bronze anodized; Industries Limited/ Steel-Crat Door-Aluminum, finish bronze anodized Door Products

Fleming Doors Products/ Daybar Industries Limited/Steel-Craft

Frame: Aluminum, finish bronze anodized; Indust

Door:Aluminum, finish bronze anodized Door Products Lto.

Fleming Doors Products/ Daybar

Frame: Aluminum, finish bronze anodized; Industries Limited/Steel-Craft

Door:Aluminum, finish bronze anodized Door Products Ltd.

Fleming Doors Products/Daybar - Steel: ASTM A568/A568M, Class 1; Commercia rame: Aluminum, finish bronze anodized; Industries Limited/ Steel-Craft Door:Aluminum, finish bronze anodized Door Products Ltd.

ASTM A653/A653M, ZF120 galvanized coating.

Steel: ASTM A568/A568M, Class 1; Commercia Industries Limited/Steel-Craft

Door Products Ltd.

grade steel, hot dip galvanized to

Door:Aluminum, finish bronze anodize

Fleming Doors Products/ Daybar

Frame: Aluminum, finish bronze anodized; Industries Limited/Steel-Craft

Fleming Doors Products/ Daybar

Fleming Doors Products/ Daybar

Frame: Aluminum, finish bronze anodized; Industries Limited/ Steel-Craft

Door:Aluminum, finish bronze anodized Door Products Lto.

Fleming Doors Products/ Daybar Steel: ASTM A568/A568M, Class 1; Commercia Frame: Aluminum, finish bronze anodized; Industries Limited/ Steel-Craft Door:Aluminum, finish bronze anodized Door Products Ltd.

, Class 1; Commercia Indust Doors Products/ Daybar

Door Products Ltd.

grade steel, hot dip galvanized to

Door:Aluminum, finish bronze anodized

.

leming Doors Products/ Daybar Steel: ASTM A568/A568M, Class 1; Commercia

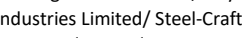
Door Products Ltd.

Steel: ASTM A568/A568M, Class $1 ; C$
grade steel, hot dip galvanized to

Door:Hollow Metal, finish pain

Fleming Doors Products/ Daybar Industries Limited/ Steel-Craft Door Products Ltd.

.

Frame: Hollow Metal, finish pain

Door:Hollow Metal, finish paint

Frame: Hollow Metal, finish paint

Door:Hollow Metal, finish paint

ASTM A653/A653M, ZF120 galvanized coating.

Fleming Doors Products/Daybar Industries Limited/Steel-Craft Door Products Ltd.

Fleming Doors Products/ Daybar Industries Limited/Steel-Craft Door Products Ltd.

Steel: ASTM A568/A568M, Class 1; Commercia

ASTM A653/A653M, ZF120 galvanized coating

grade steel, hot dip galvanized to

ASTM A653/A653M, ZF120 galvanized coating.

\section{Tally - Doors}

specification

Spection

D101

Thicknes

ONE-CLICK LCA

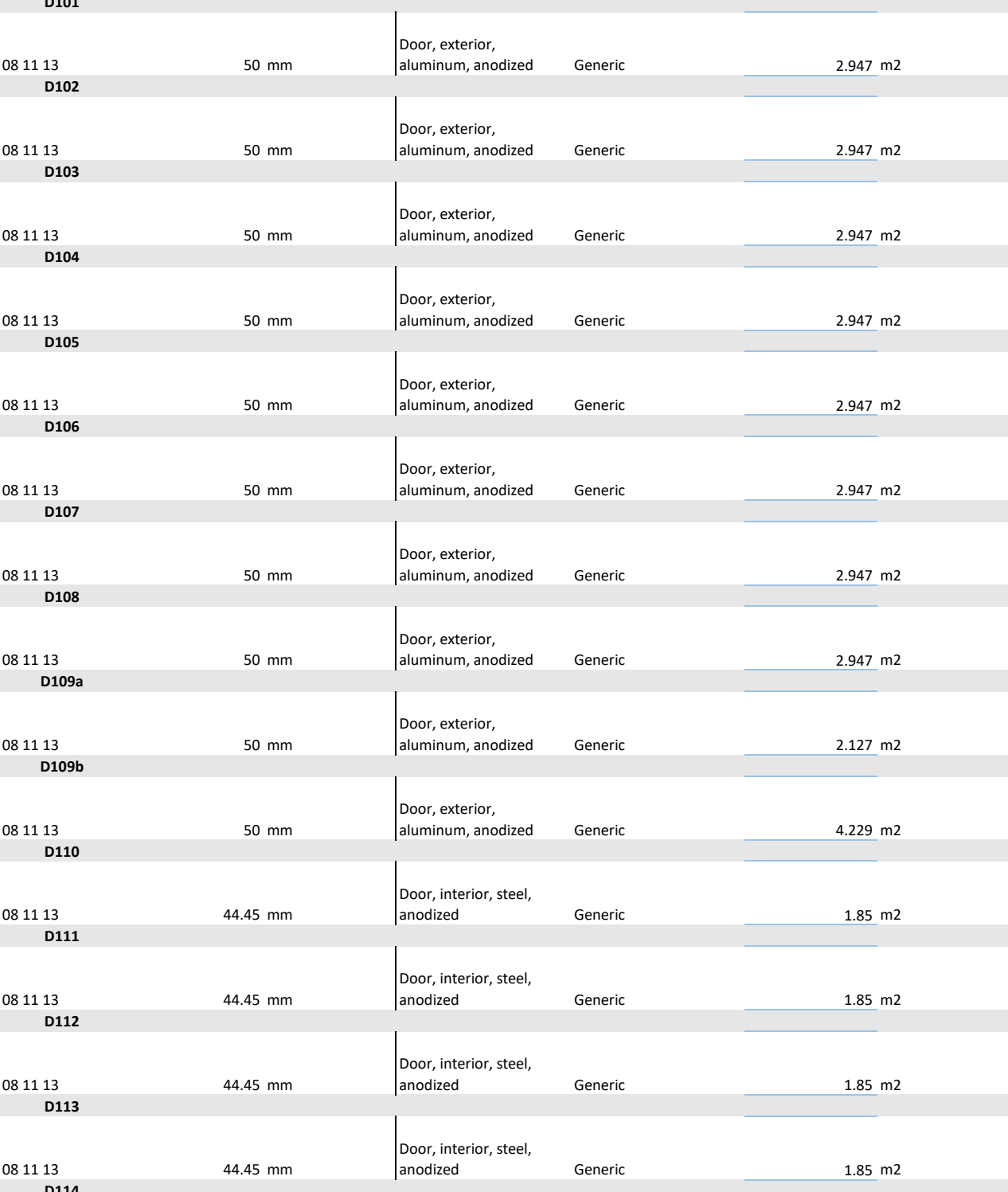

(a)

(n)


Frame: Hollow Metal, finish paint; Door:Hollow Metal, finish paint

\section{Frame: Hollow Metal, finish paint;} Door:Hollow Metal, finish paint

Frame: Hollow Metal, finish paint; Door:Hollow Metal, finish paint

Frame: Hollow Metal finish pint;

Frame: Hollow Metal, finish
Door:Hollow Metal, finish p

Door:Hollow Metal, finish paint

Frame: Hollow Metal, finish paint; Door:Hollow Metal, finish paint

Frame: Hollow Metal, finish paint; Door:Hollow Metal, finish paint

\section{Frame: Hollow Metal, finish paint;} Door:Hollow Metal, finish paint

\section{Frame: Hollow Metal, finish paint;} Door:Hollow Metal, finish paint

Frame: Hollow Metal, finish paint;

Door:Hollow Metal, finish paint

Frame: Hollow Metal, finish paint; Door:Hollow Metal, finish paint

Dor. Hollow Mel, thish pant

Frame: Hollow Metal, finish pain Door:Hollow Metal, finish paint

\section{Frame: Hollow Metal, finish paint;} Door:Hollow Metal, finish paint

Frame: Hollow Metal, finish paint; Door:Hollow Metal, finish paint

Door How Metil fins

Door:Hollow Metal, finish paint

Frame: Hollow Metal, finish paint; Door:Hollow Metal, finish paint

Frame: Hollow Metal, finish paint; Door:Hollow Metal, finish paint
Fleming Doors Products/ Daybar Industries Limited/Steel-Craft Door Products Ltd.

Steel: ASTM A568/A568M, Class 1; Commercia grade steel, hot dip galvanized to

/A653M, ZF 120 galvanized coating.

Fleming Doors Products/ Daybar Steel: ASTM A568/A568M, Class 1; Commercia dustries Limited/Steel-Craft grade steel, hot dip galvanized to Door Products Lt

ASTM A653/A653M, ZF120 galvanized coating.

Fleming Doors Products/ Daybar Steel: ASTM A568/A568M, Class 1; Commercial d grade steel, hot dip galvanized to Door Products Ltd

Ivanized coatin

Fleming Doors Products/ Daybar Steel: ASTM A568/A568M, Class 1; Commercia Industries Limited/Steel-Craft grade steel, hot dip galvanized to

Door Products Ltd. ASTM A653/A653M, ZF120 galvanized coating.

Fleming Doors Products/ Daybar Steel: ASTM A568/A568M, Class 1; Commercia Industries Limited/Steel-Craft grade steel, hot dip galvanized to

Door Products Ltd. ASTM A653/A653M, ZF120 galvanized coating.

Fleming Doors Products/ Daybar Steel: ASTM A568/A568M, Class 1; Commercia Industries Limited/Steel-Craft grade steel, hot dip galvanized to

Door Products Ltd. ASTM A653/A653M, ZF120 galvanized coating.

Fleming Doors Products/ Daybar Steel: ASTM A568/A568M, Class 1; Commercia Industries Limited/ Steel-Craft grade steel, hot dip galvanized to

ASTM A653/A653M, ZF120 galvanized coating.

Fleming Doors Products/ Daybar Steel: ASTM A568/A568M, Class 1; Commercial

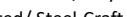
grade steel, hot dip galvanized to Door Products Ltd.

Fleming Doors Products/ Daybar Steel: ASTM A568/A568M, Class 1; Commercia Industries Limited/Steel-Craft grade steel, hot dip galvanized to

Door Products Ltd. ASTM A653/A653M, ZF120 galvanized coating.

Fleming Doors Products/ Daybar Steel: ASTM A568/A568M, Class 1; Commercia Industries Limited/ Steel-Craft grade steel, hot dip galvanized to

Door Products Ltd. ASTM A653/A653M, ZF120 galvanized coating.

Fleming Doors Products/ Daybar Steel: ASTM A568/A568M, Class 1; Commercia Industries Limited/Steel-Craft grade steel, hot dip galvanized to

Door Products Ltd. ASTM A653/A653M, ZF120 galvanized coating.

Fleming Doors Products/ Daybar Steel: ASTM A568/A568M, Class 1; Commerci Industries Limited/Steel-Craft grade steel, hot dip galvanized to

ASTM A653/A653M, ZF120 galvanized coating.

Fleming Doors Products/ Daybar Steel: ASTM A568/A568M, Class 1; Commercia Industries Limited/ Steel-Craft $\quad$ grade steel, hot dip galvanized to

ASTM A653/A653M, ZF120 galvanized coatin.

Fleming Doors Products/ Daybar Steel: ASTM A568/A568M, Class 1; Commercia Industries Limited/Steel-Craft grade steel, hot dip galvanized to

Door Products Ltd. ASTM A653/A653M, ZF120 galvanized coating.

Fleming Doors Products/Daybar Steel: ASTM A568/A568M, Class 1; Commercia Industries Limited/ Steel-Craft grade steel, hot dip galvanized to

Door Products Ltd. ASTM A653/A653M, ZF120 galvanized coating.

Fleming Doors Products/ Daybar Steel: ASTM A568/A568M, Class 1; Commercia Industries Limited/Steel-Craft grade steel, hot dip galvanized to

Door Products Ltd. ASTM A653/A653M, ZF120 galvanized coating.

\begin{tabular}{|c|c|c|c|c|}
\hline $\begin{array}{l}081113 \\
\text { D115 }\end{array}$ & $44.45 \mathrm{~mm}$ & $\begin{array}{l}\text { Door, interior, steel, } \\
\text { anodized }\end{array}$ & Generic & $1.85 \mathrm{~m} 2$ \\
\hline 081113 & $44.45 \mathrm{~mm}$ & $\begin{array}{l}\text { Door, interior, steel, } \\
\text { anodized }\end{array}$ & Generic & $1.85 \mathrm{~m} 2$ \\
\hline $\begin{array}{l}081113 \\
\text { D117 }\end{array}$ & $44.45 \mathrm{~mm}$ & $\begin{array}{l}\text { Door, interior, steel, } \\
\text { anodized }\end{array}$ & Generic & $1.85 \mathrm{~m} 2$ \\
\hline $\begin{array}{l}081113 \\
\text { D118 }\end{array}$ & $44.45 \mathrm{~mm}$ & $\begin{array}{l}\text { Door, interior, steel, } \\
\text { anodized }\end{array}$ & Generic & $1.85 \mathrm{~m} 2$ \\
\hline $\begin{array}{l}081113 \\
\text { D119 }\end{array}$ & $44.45 \mathrm{~mm}$ & $\begin{array}{l}\text { Door, interior, steel, } \\
\text { anodized }\end{array}$ & Generic & $1.85 \mathrm{~m} 2$ \\
\hline $\begin{array}{l}081113 \\
\text { D120 }\end{array}$ & $44.45 \mathrm{~mm}$ & $\begin{array}{l}\text { Door, interior, steel, } \\
\text { anodized }\end{array}$ & Generic & $1.85 \mathrm{~m} 2$ \\
\hline $\begin{array}{l}081113 \\
\text { D121 }\end{array}$ & $44.45 \mathrm{~mm}$ & $\begin{array}{l}\text { Door, interior, steel, } \\
\text { anodized }\end{array}$ & Generic & $1.85 \mathrm{~m} 2$ \\
\hline $\begin{array}{l}081113 \\
\text { D122 }\end{array}$ & $44.45 \mathrm{~mm}$ & $\begin{array}{l}\text { Door, interior, steel, } \\
\text { anodized }\end{array}$ & Generic & $1.85 \mathrm{~m} 2$ \\
\hline $\begin{array}{l}081113 \\
\text { D123 }\end{array}$ & $44.45 \mathrm{~mm}$ & \begin{tabular}{|l} 
Door, interior, steel, \\
anodized
\end{tabular} & Generic & $1.85 \mathrm{~m} 2$ \\
\hline $\begin{array}{l}081113 \\
\text { D124 }\end{array}$ & $44.45 \mathrm{~mm}$ & $\begin{array}{l}\text { Door, interior, steel, } \\
\text { anodized }\end{array}$ & Generic & $1.85 \mathrm{~m} 2$ \\
\hline $\begin{array}{l}081113 \\
\text { D125 }\end{array}$ & $44.45 \mathrm{~mm}$ & \begin{tabular}{|l} 
Door, interior, steel, \\
anodized
\end{tabular} & Generic & $1.85 \mathrm{~m} 2$ \\
\hline 081113 & $44.45 \mathrm{~mm}$ & \begin{tabular}{|l} 
Door, interior, steel, \\
anodized
\end{tabular} & Generic & $1.85 \mathrm{~m} 2$ \\
\hline 081113 & $44.45 \mathrm{~mm}$ & $\begin{array}{l}\text { Door, interior, steel, } \\
\text { anodized }\end{array}$ & Generic & $1.85 \mathrm{~m} 2$ \\
\hline 081113 & $44.45 \mathrm{~mm}$ & $\begin{array}{l}\text { Door, interior, steel, } \\
\text { anodized }\end{array}$ & Generic & $1.85 \mathrm{m2}$ \\
\hline D128 & & & & \\
\hline $\begin{array}{l}081113 \\
\text { D129 }\end{array}$ & $44.45 \mathrm{~mm}$ & $\begin{array}{l}\text { Door, interior, steel, } \\
\text { anodized }\end{array}$ & Generic & $1.85 \mathrm{~m} 2$ \\
\hline 081113 & $44.45 \mathrm{~mm}$ & $\begin{array}{l}\text { Door, interior, steel, } \\
\text { anodized }\end{array}$ & Generic & $1.85 \mathrm{~m} 2$ \\
\hline
\end{tabular}


Frame: Hollow Metal, finish paint; Door:Hollow Metal, finish paint

Frame: Hollow Metal, finish paint; Door:Hollow Metal, finish paint

Frame: Hollow Metal, finish paint; Door:Hollow Metal, finish paint

Frame: Hollow Metal finish paint;

Frame:Hollow Metal finish paint;

Door.Holow Metal, finsh paint

Frame: Hollow Metal, finish paint; Door:Hollow Metal, finish paint

Fleming Doors Products/ Daybar rame: Aluminum, finish bronze anodized; Industries Limited/Steel-Craft Door:Aluminum, finish bronze anodized Door Products Ltd.

Fleming Doors Products/ Daybar Steel: ASTM A568/A568M, Class 1; Commercia Door Products Ltd.

Frame: Aluminum, finish bronze anodizd Door:Aluminum, finish bronze anodized

Frame: Hollow Metal, finish paint;

Fleming Doors Products/ Daybr Industries Limited/Steel-Craft

Fleming Doors Products/ Daybar

Door Products Itd

Fleming Doors Products/Daybar

Door:Aluminum, finish bronze anodized

Frame: Aluminum, finish bronze anodized; Industries Limited/Steel-Craft Door:Aluminum, finish bronze anodized Door Products Ltd.

Fleming Doors Products/ Daybar ndustries Limited/Steel-Craft Door Products Ltd.

Frame: Hollow Metal, finish paint

Fleming Doors Products/ Daybar Industries Limited/Steel-Craft

Door Products Ltc.

Fleming Doors Products/ Daybar

Door:Aluminum, finish bronze anodized

-eel-Craft

Frame: Aluminum, finish bronze anodized; Industries Limited/Sted
Steel: ASTM A568/A568M, Class 1; Commercial ASTM A653/A653M, ZF120 galvanized coating.

Steel: ASTM A568/A568M, Class 1; Commercia grade steel, hot dip galvanized to

ASTM A653/A653M, ZF120 galvanized coating.

Steel: ASTM A568/A568M, Class 1; Commercial grade steel, hot dip galvanized to

ASTM A653/A653M, ZF120 galvanized coating.

Steel: ASTM A568/A568M, Class 1; Commercia grade steel, hot dip galvanized to

Steel: ASTM A568/A568M, Class 1; Commercia rade steel, hot dip galvanized to

ATTM A653/A653M, ZF120 galva

el: ASTM A568/A568M, Class 1; Commercia (ip galvanized to grade steel, hot dip galvanized to

ASTM A653/A653M, ZF120 galvanized coating.

Steel: ASTM A568/A568M, Class 1; Commercia grade steel, hot dip galvanized to

galvanized coating.

Steel: ASTM A568/A568M, Class 1; Commercia grade steel, hot dip galvanized to

ASTM A653/A653M, ZF120 galvanized coating.

Steel: ASTM A568/A568M, Class 1; Commercia rrade steel, hot dip galvanized to

ASTM A653/A653M, ZF120 galvanized coating.

Steel: ASTM A568/A568M, Class 1; Commercia grade steel, hot dip galvanized to

ASTM A653/A653M, ZF120 galvanized coating.

Steel: ASTM A568/A568M, Class 1; Commercia grade steel, hot dip galvanized to

ASTM A653/A653M, ZF120 galvanized coating.

Steel: ASTM A568/A568M, Class 1; Commercial grade steel, hot dip galvanized to

.
ASTM A653/A653M, ZF120 galvanized coatin

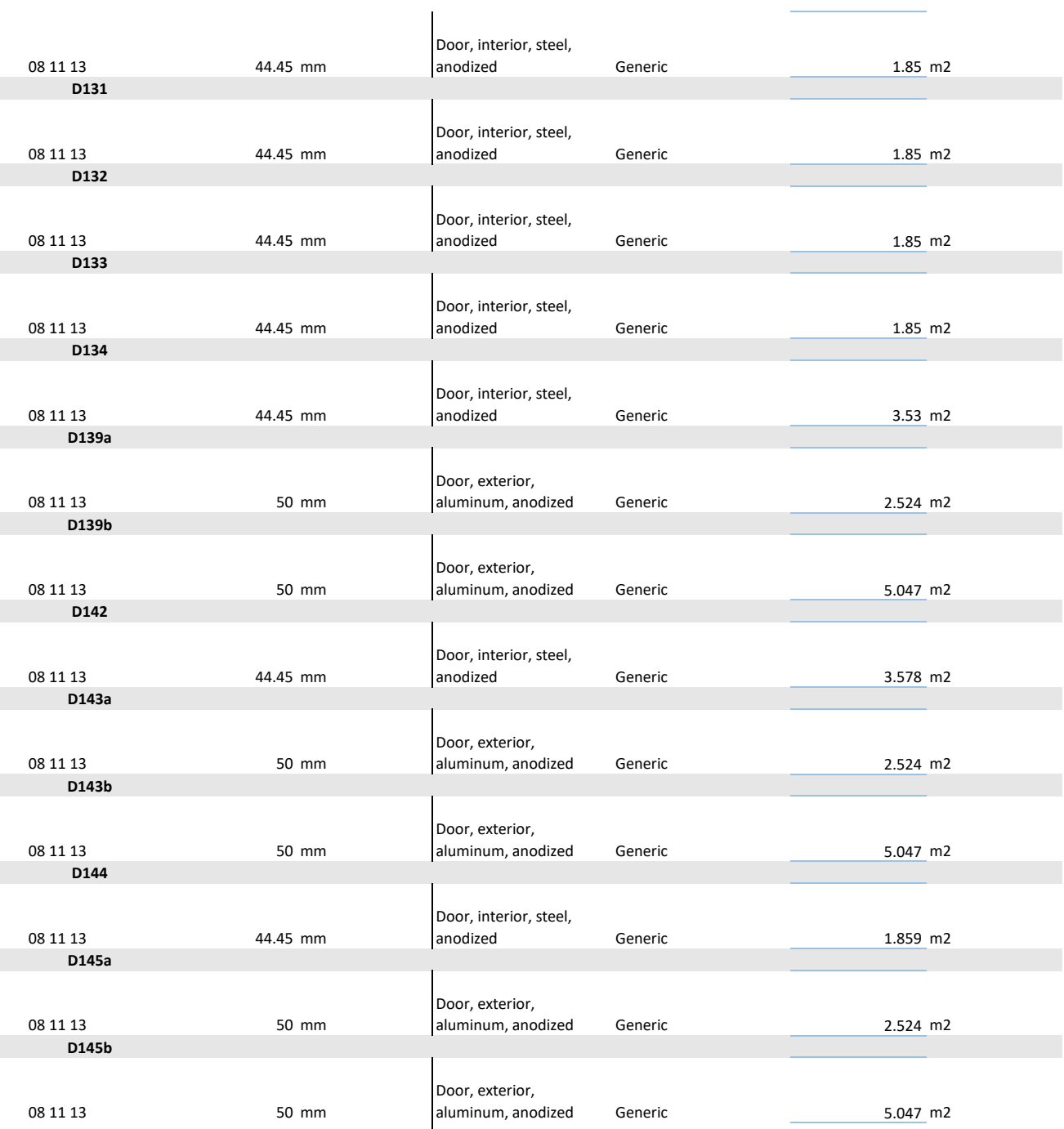




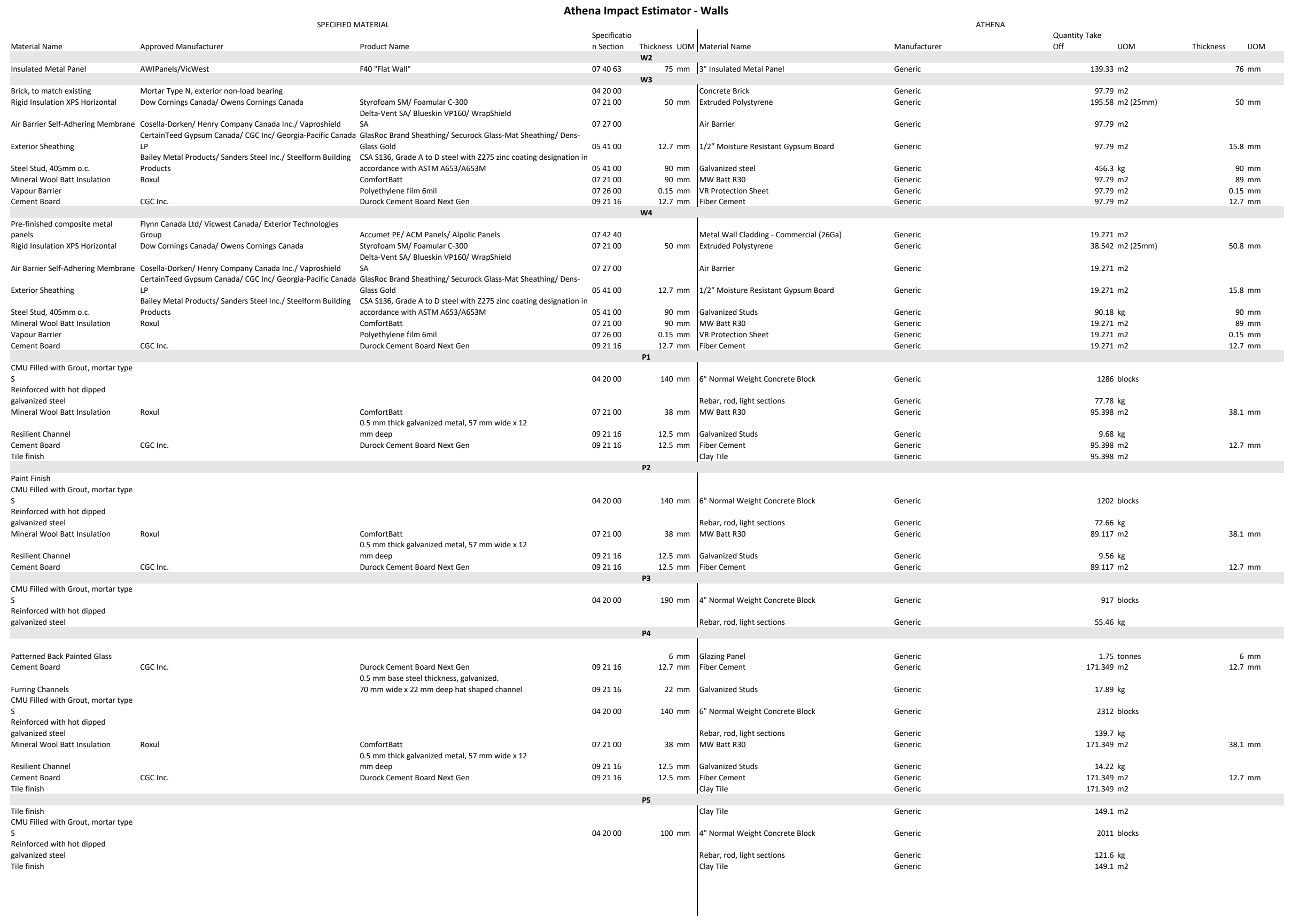


Athena Impact Estimator - Curtain Wall/Windows

SPECIFIED MATE

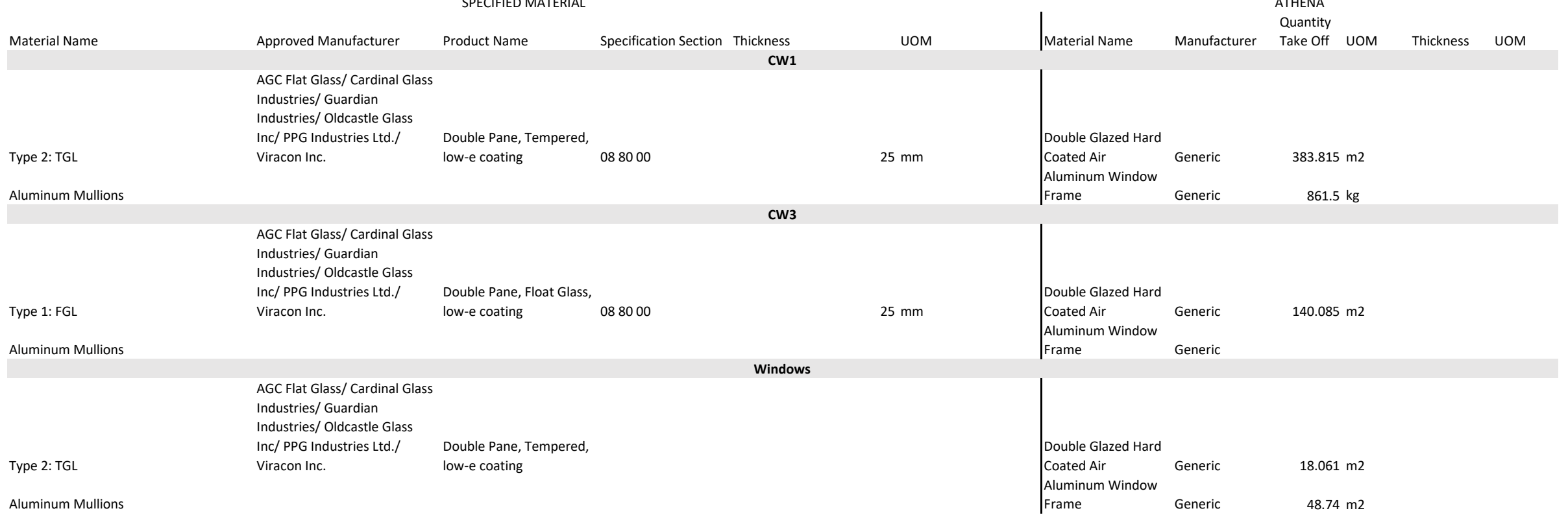




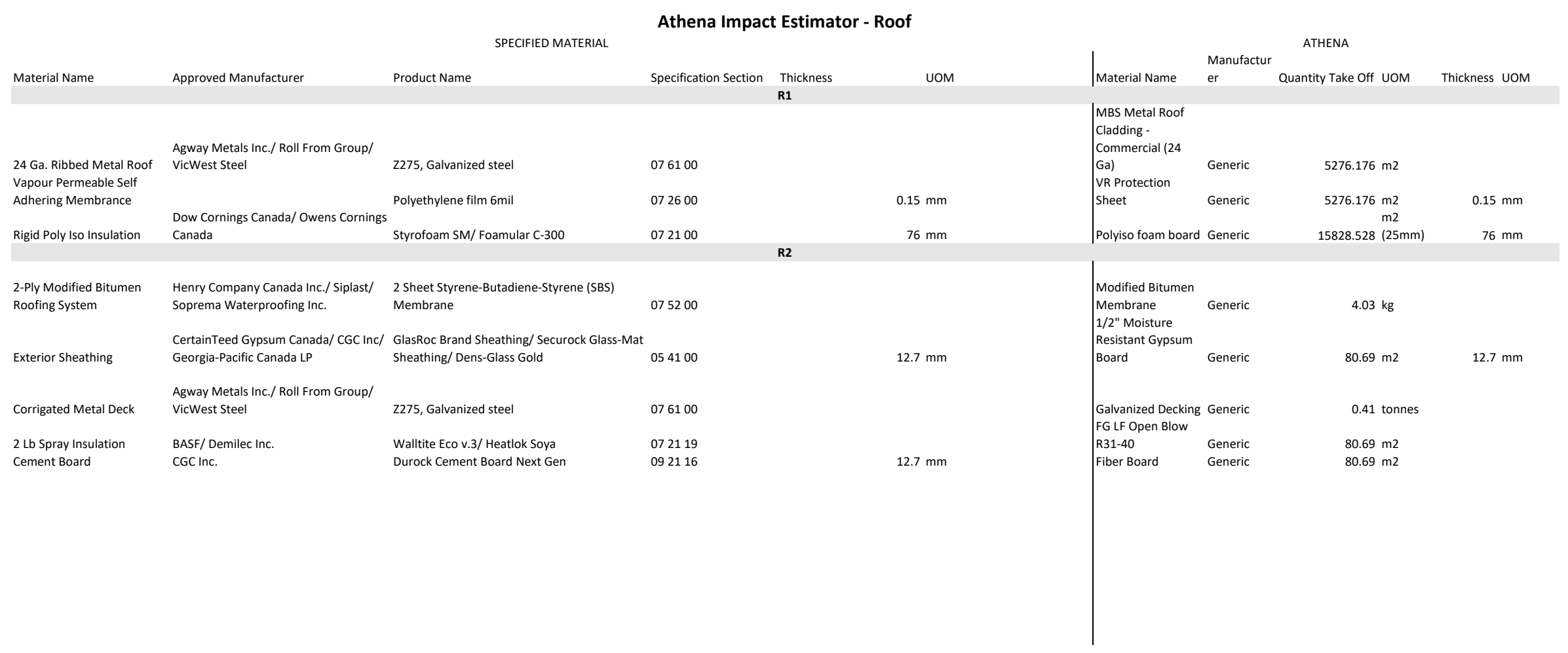




\begin{tabular}{|c|c|c|c|c|c|c|c|c|c|}
\hline \multicolumn{10}{|c|}{ Athena Impact Estimator - Ceiling } \\
\hline \multirow[b]{2}{*}{ Material Name } & \multirow{2}{*}{ Approved Manufacturer } & \multirow[t]{2}{*}{ SPECIFIED MATERIAL } & \multirow{3}{*}{$\begin{array}{l}\text { Specification } \\
\text { Section }\end{array}$} & \multirow[b]{2}{*}{ Thickness } & \multirow{3}{*}{ UOM } & \multirow{2}{*}{ |Material Name } & \multirow{2}{*}{$\begin{array}{l}\text { ATHEN } \\
\text { Manufact } \\
\text { urer }\end{array}$} & & \multirow{2}{*}{ Thickness UOM } \\
\hline & & & & & & & & $\begin{array}{l}\text { NA } \\
\text { Quantity } \\
\text { Take Off }\end{array}$ & \\
\hline & & & & C2 & & & & & \\
\hline \multirow{4}{*}{ Steel Deck } & Agway Metals Inc./ Roll From & & & & & & & & \\
\hline & Group/VicWest Steel & Z275, Galvanized steel & 076100 & & & Galvanized Decking & Generic & 0.67 tonnes & \\
\hline & & CSA S136, Grade A to D steel with & & & & & & & \\
\hline & $\begin{array}{l}\text { Bailey Metal Products/ } \\
\text { Sanders Steel Inc./ Steelform }\end{array}$ & $\begin{array}{l}\text { Z275 zinc coating designation in } \\
\text { accordance with ASTM }\end{array}$ & & & & & & & \\
\hline Metal Stud & Building Products & A653/A653M & 054100 & & $89 \mathrm{~mm}$ & Galvanized studs & Generic & $176 \mathrm{~kg}$ & \\
\hline Mineral Wool Acoustical & & & & & & & & $\mathrm{m} 2$ & \\
\hline \multirow[t]{2}{*}{ Batts } & Roxul & ComfortBatt & 072100 & & $89 \mathrm{~mm}$ & MW Batt R30 & Generic & $519.362(25 \mathrm{~mm})$ & $88 \mathrm{~mm}$ \\
\hline & & $\begin{array}{l}0.5 \mathrm{~mm} \text { thick galvanized metal, } 57 \\
\mathrm{~mm} \text { wide } \times 12\end{array}$ & & & & & & & \\
\hline \multirow{2}{*}{ Resilient Channel } & & $\mathrm{mm}$ deep & 092116 & & $12.5 \mathrm{~mm}$ & Galvanized studs & Generic & $14.45 \mathrm{~kg}$ & \\
\hline & $\begin{array}{l}\text { Certainteed Gypsum Canada, } \\
\text { CGC Inc./ Georgia-Pacific }\end{array}$ & & & & & & & & \\
\hline Gypsum Wall Board & Canada LP & Furnish Board & 092116 & & $12.5 \mathrm{~mm}$ & 1/2" Regular Gypsum Board & Generic & $129.84 \mathrm{~m} 2$ & $12.7 \mathrm{~mm}$ \\
\hline \multicolumn{10}{|c|}{ C3 } \\
\hline Reinforced Concrete & & & & & & Concrete Benchmark 2500psi & Generic & $9.325 \mathrm{~m} 3$ & \\
\hline \multirow[t]{2}{*}{ Reinforcing } & & & & & & Rebar, rod, light sections & Generic & $54.24 \mathrm{~kg}$ & \\
\hline & Agway Metals Inc./ Roll From & & & & & & & & \\
\hline Steel Deck & Group/VicWest Steel & Z275, Galvanized steel & 076100 & & & Galvanized Decking & Generic & 0.32 tonnes & \\
\hline
\end{tabular}




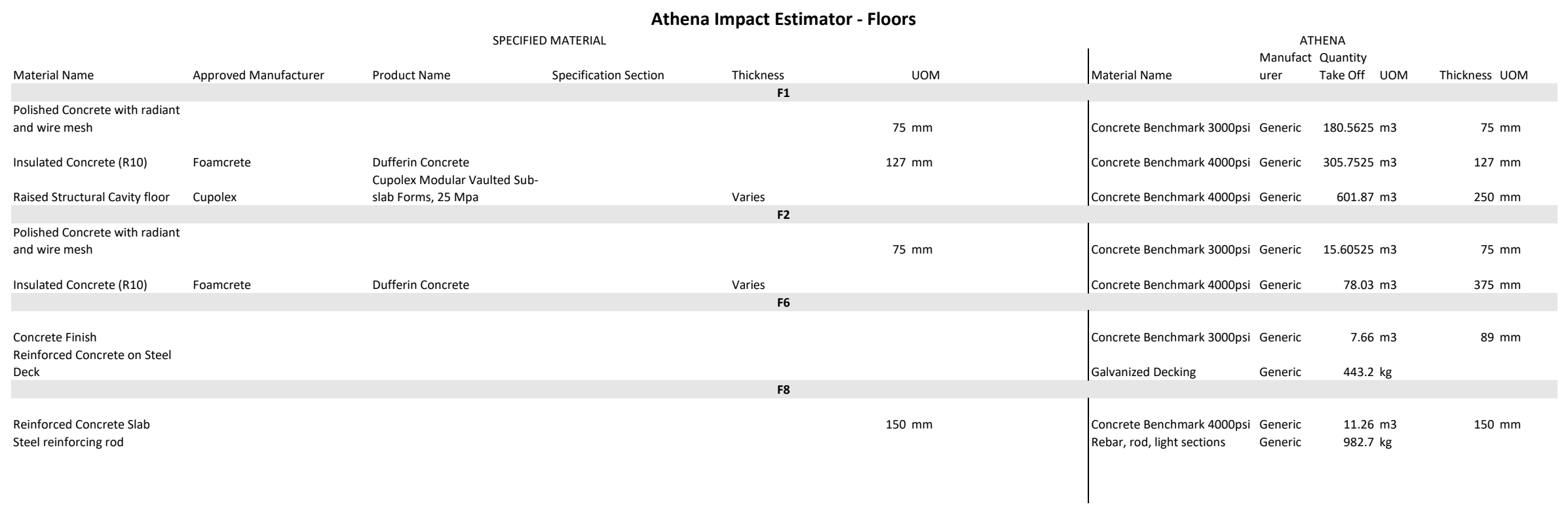




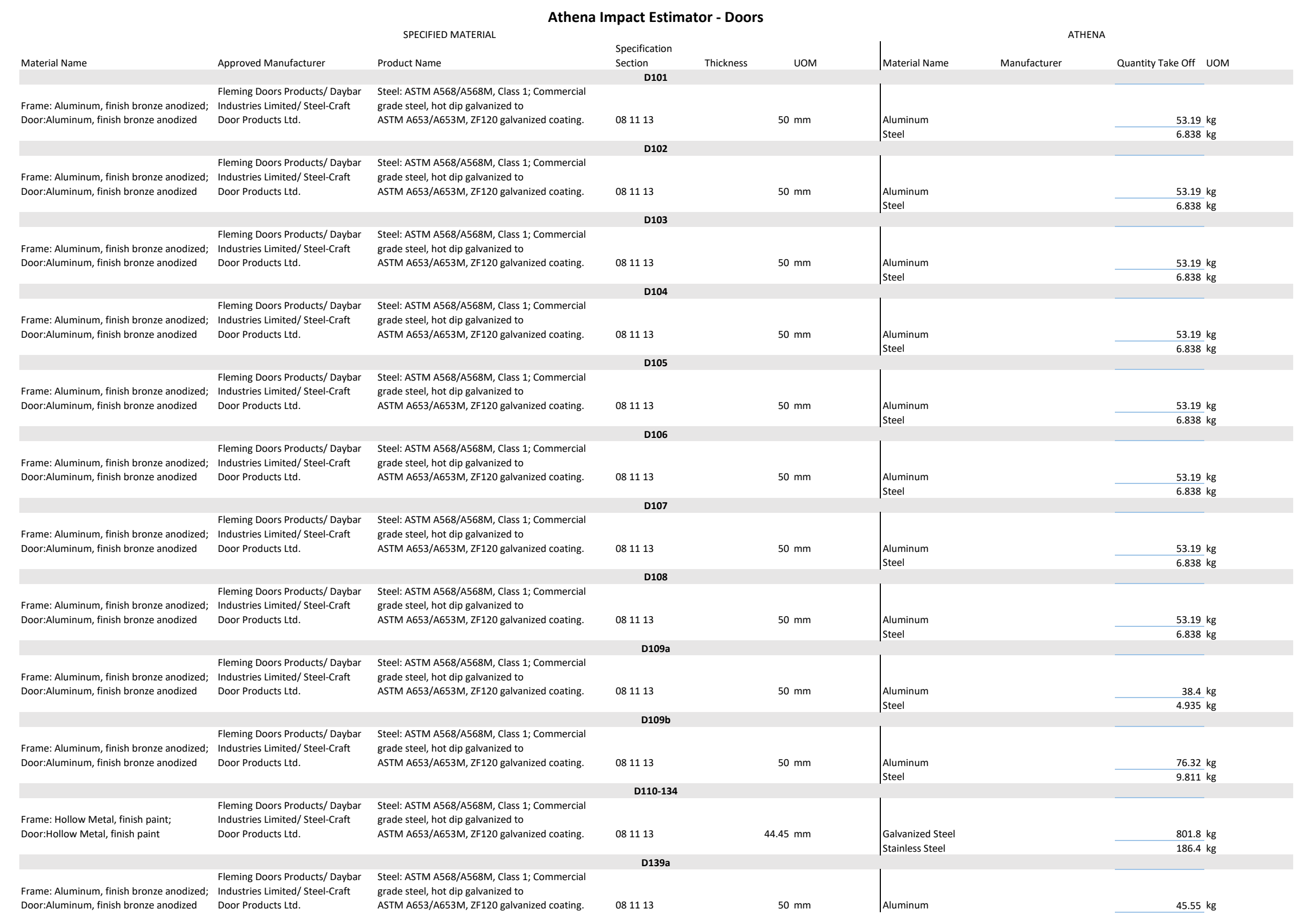




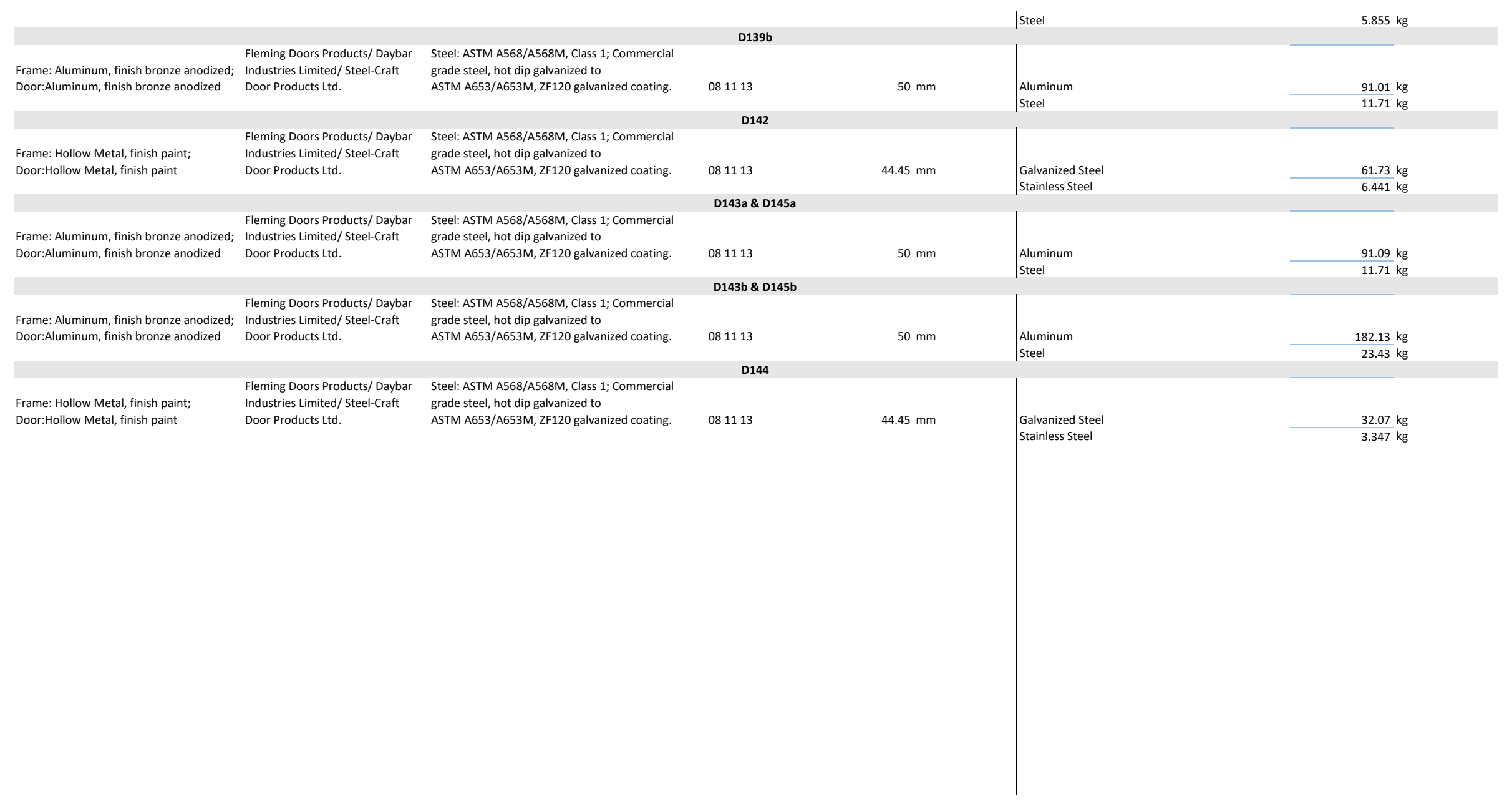




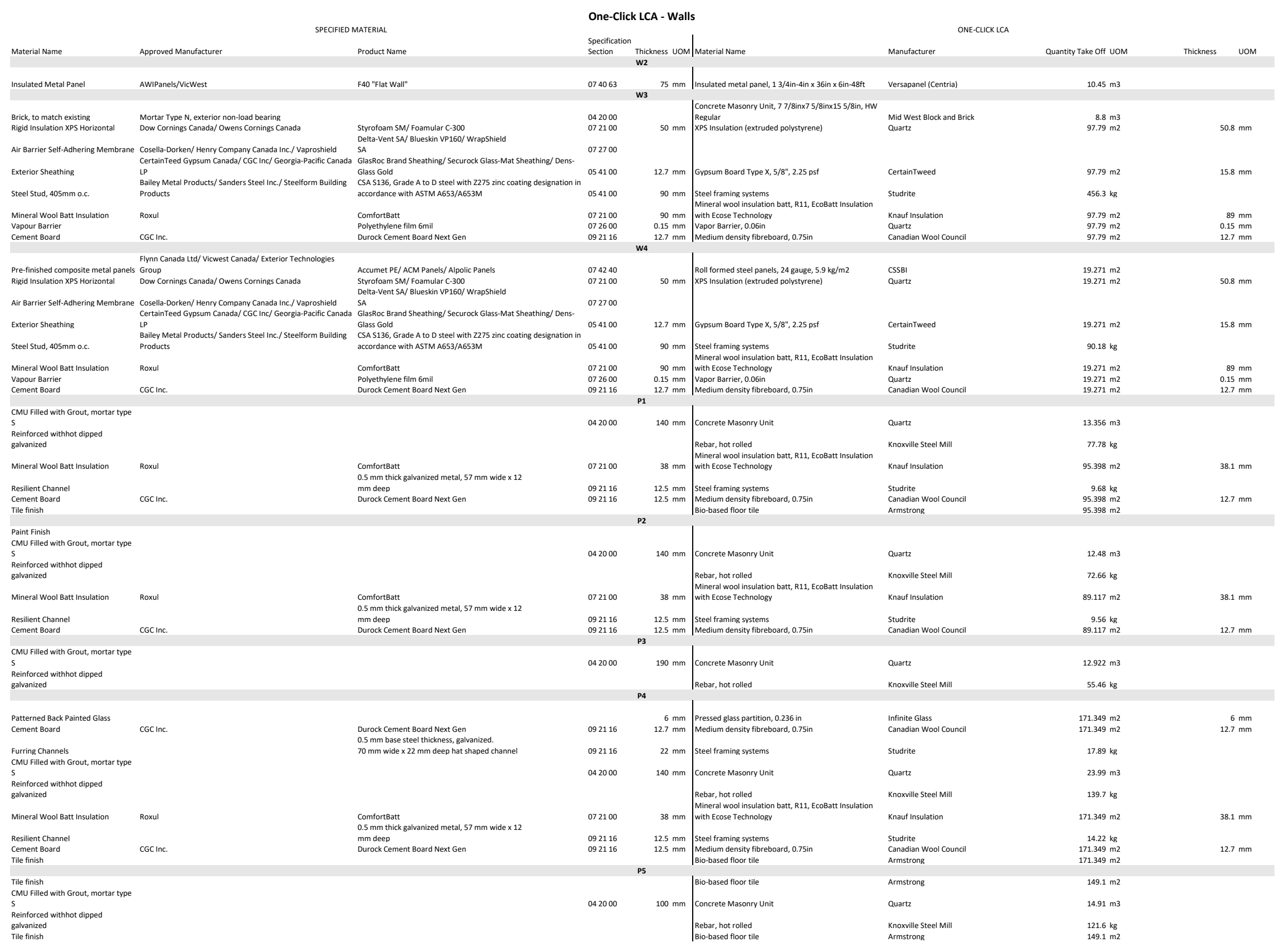




\section{One-Click LCA - Curtain Wall/Windows}

SPECIFIED MATERIAL

Material Name

Approved Manufacturer

Product Name

Specification Section Thickness

AGC Flat Glass/ Cardinal Glass

Industries/Guardian

Industries/Oldcastle Glass

Inc/ PPG Industries Ltd./

Double Pane, Tempered,

Type 2: TGL

low-e coating

AGC Flat Glass/ Cardinal Glass

Industries/ Guardian

Industries/ Oldcastle Glass

Inc/ PPG Industries Ltd./

Viracon Inc.

Double Pane, Float Glass,

low-e coating $\quad 088000$

088000

AGC Flat Glass/ Cardinal Glass

Industries/Guardian

Industries/ Oldcastle Glass

Inc/ PPG Industries Ltd./

Double Pane, Tempered,

Type 2: TGL
CW1

บOM

ONE-CLICK LCA

Quantity

Material Name Manufacturer Take Off UOM Thickness UOM

Traditional Curtain

Wall, $1.5 \mathrm{mx} \times 1.6 \mathrm{~m}$

Wall, $1.5 \mathrm{~m} \times 1.6 \mathrm{~m}$

$\begin{array}{lll}\text { wall system } \quad \text { Kawneer } & 383.815 \mathrm{~m} 2\end{array}$

CW3

$25 \mathrm{~mm}$

Traditional Curtain

Wall $1.5 \mathrm{~m} \times 1.6 \mathrm{~m}$

and clearwall

curtainl wall system Kawneer $\quad 140.085 \mathrm{~m} 2$

$25 \mathrm{~mm}$

Aluminum window,

$\begin{array}{lll}\text { fixed and ribbon } \quad \text { Kawneer } & 18.061 \mathrm{~m} 2\end{array}$ 


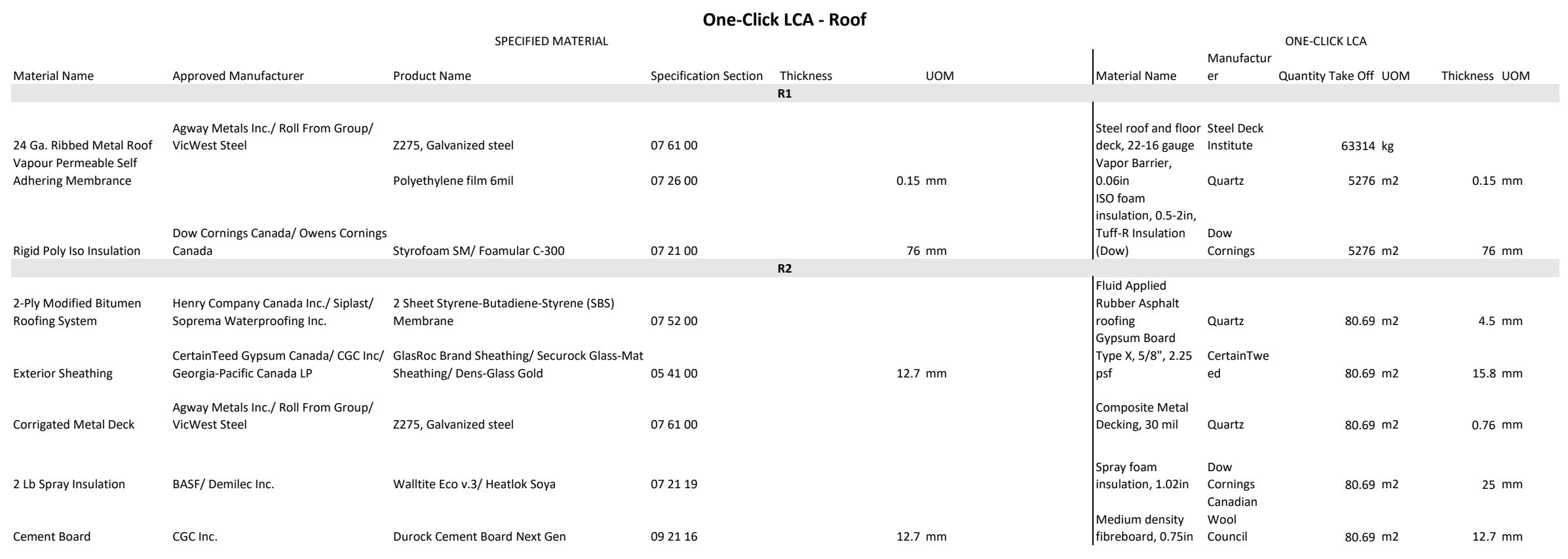




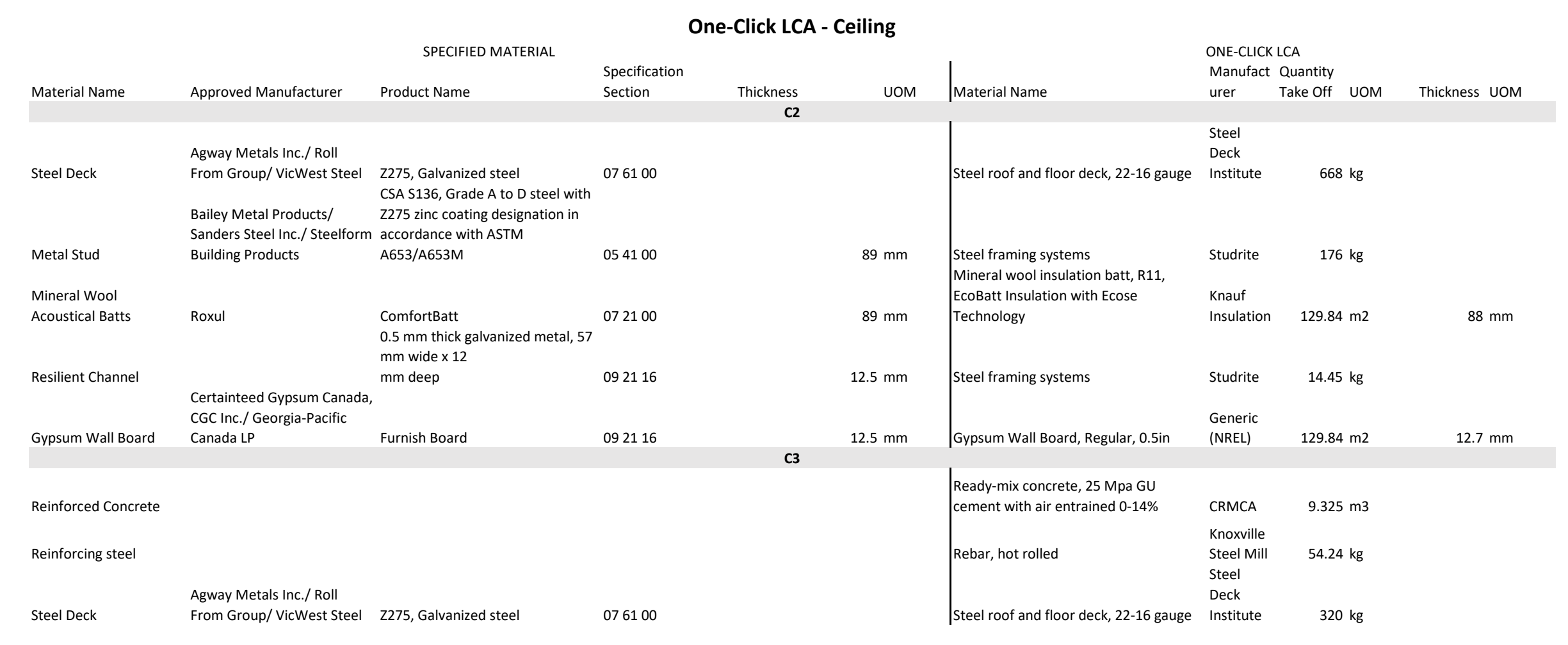




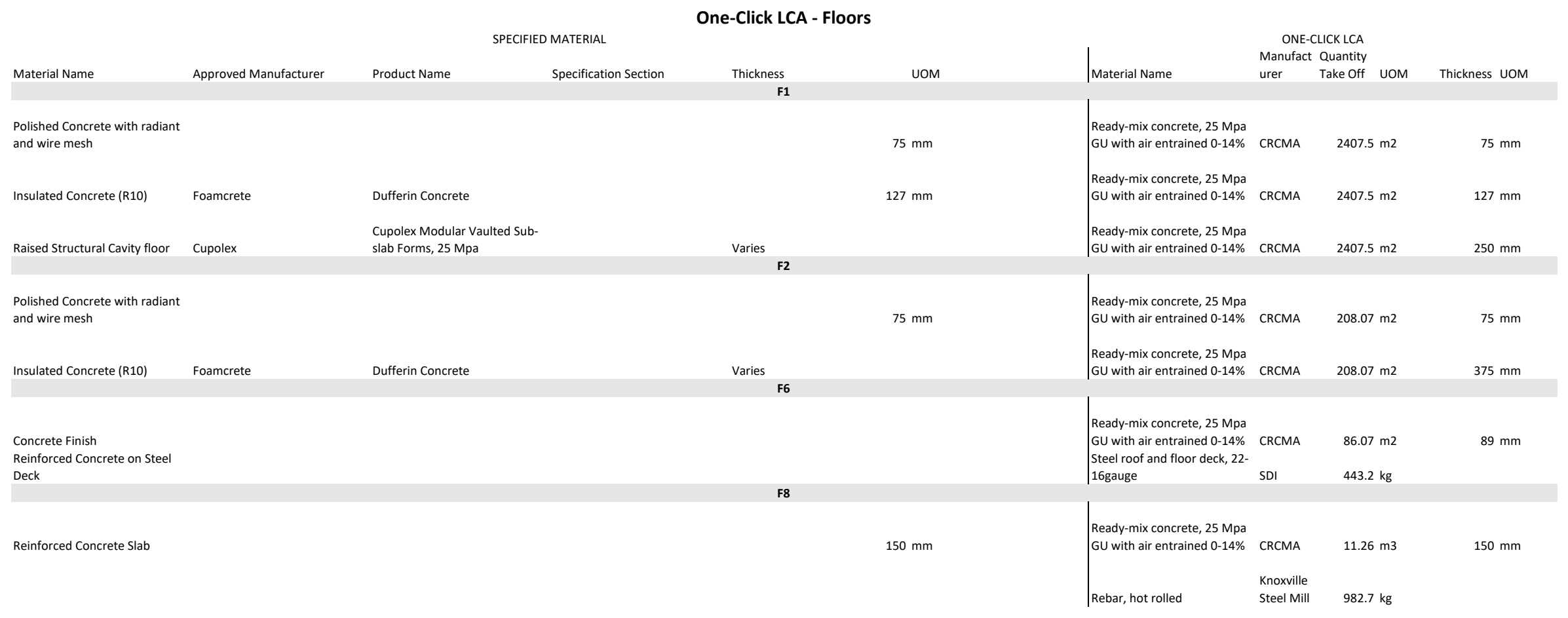




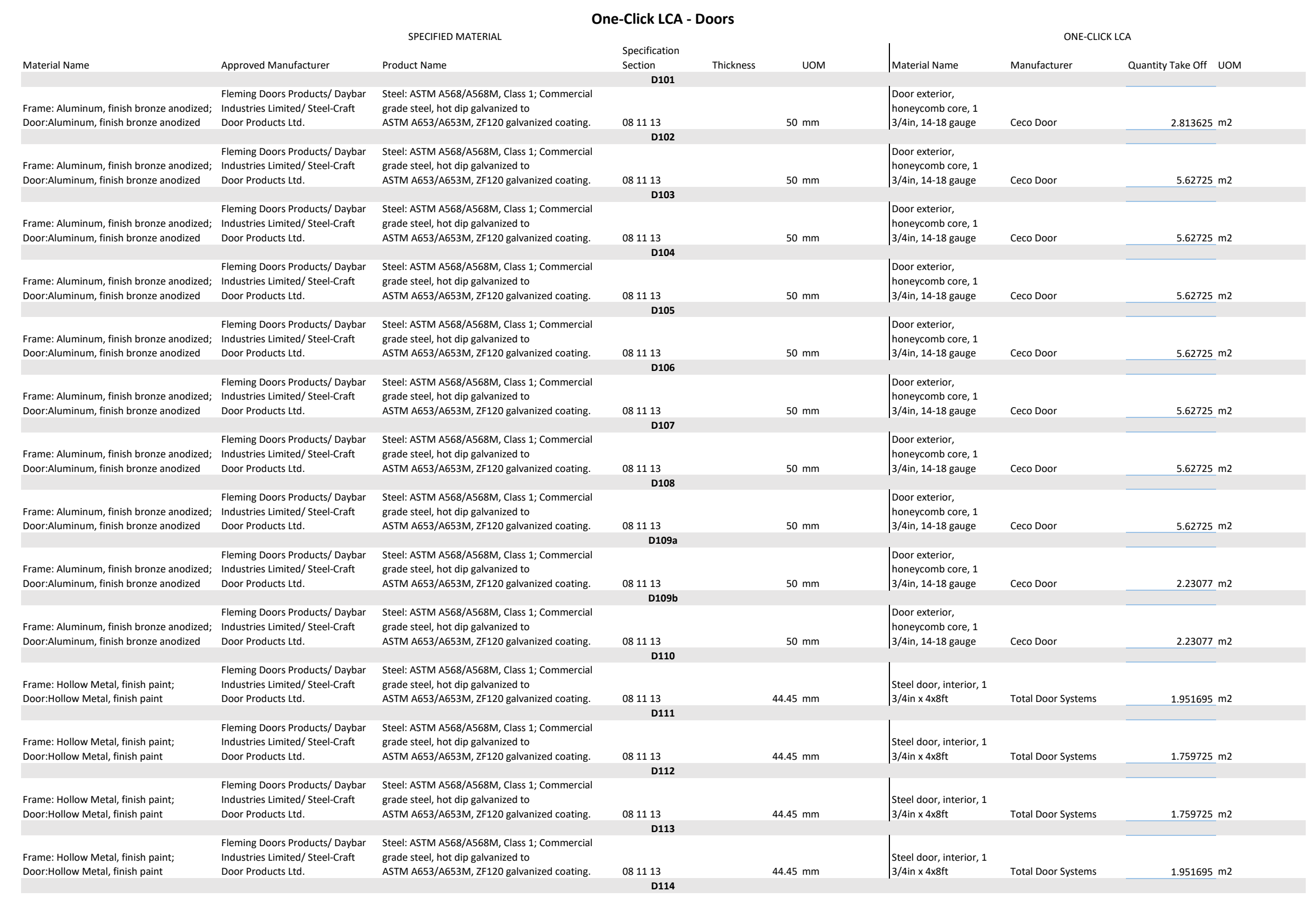




\begin{tabular}{|c|c|c|c|c|c|c|c|}
\hline $\begin{array}{l}\text { Frame: Hollow Metal, finish paint; } \\
\text { Door:Hollow Metal, finish paint }\end{array}$ & $\begin{array}{l}\text { Fleming Doors Products/ Daybar } \\
\text { Industries Limited/Steel-Craft } \\
\text { Door Products Ltd. }\end{array}$ & $\begin{array}{l}\text { Steel: ASTM A568/A568M, Class 1; Commercial } \\
\text { grade steel, hot dip galvanized to } \\
\text { ASTM A653/A653M, ZF120 galvanized coating. }\end{array}$ & 081113 & $44.45 \mathrm{~mm}$ & $\begin{array}{l}\text { Steel door, interior, } 1 \\
3 / 4 \text { in } \times 4 \times 8 \mathrm{ft}\end{array}$ & Total Door Systems & $1.759725 \mathrm{~m} 2$ \\
\hline $\begin{array}{l}\text { Frame: Hollow Metal, finish paint; } \\
\text { Door:Hollow Metal, finish paint }\end{array}$ & $\begin{array}{l}\text { Fleming Doors Products/ Daybar } \\
\text { Industries Limited/Steel-Craft } \\
\text { Door Products Ltd. }\end{array}$ & $\begin{array}{l}\text { Steel: ASTM A568/A568M, Class 1; Commercial } \\
\text { grade steel, hot dip galvanized to } \\
\text { ASTM A653/A653M, ZF120 galvanized coating. }\end{array}$ & 081113 & $44.45 \mathrm{~mm}$ & $\begin{array}{l}\text { Steel door, interior, } 1 \\
3 / 4 \text { in } \times 4 \times 8 \mathrm{ft}\end{array}$ & Total Door Systems & $1.759725 \mathrm{~m} 2$ \\
\hline $\begin{array}{l}\text { Frame: Hollow Metal, finish paint; } \\
\text { Door:Hollow Metal, finish paint }\end{array}$ & $\begin{array}{l}\text { Fleming Doors Products/ Daybar } \\
\text { Industries Limited/Steel-Craft } \\
\text { Door Products Ltd. }\end{array}$ & $\begin{array}{l}\text { Steel: ASTM A568/A568M, Class 1; Commercial } \\
\text { grade steel, hot dip galvanized to } \\
\text { ASTM A653/A653M, ZF120 galvanized coating. }\end{array}$ & $\begin{array}{l}081113 \\
\text { D117 }\end{array}$ & $44.45 \mathrm{~mm}$ & $\begin{array}{l}\text { Steel door, interior, } 1 \\
3 / 4 \text { in } \times 4 \times 8 \mathrm{ft}\end{array}$ & Total Door Systems & $1.759725 \mathrm{~m} 2$ \\
\hline $\begin{array}{l}\text { Frame: Hollow Metal, finish paint; } \\
\text { Door:Hollow Metal, finish paint }\end{array}$ & $\begin{array}{l}\text { Fleming Doors Products/ Daybar } \\
\text { Industries Limited/Steel-Craft } \\
\text { Door Products Ltd. }\end{array}$ & $\begin{array}{l}\text { Steel: ASTM A568/A568M, Class 1; Commercial } \\
\text { grade steel, hot dip galvanized to } \\
\text { ASTM A653/A653M, ZF120 galvanized coating. }\end{array}$ & $\begin{array}{l}081113 \\
\text { D118 }\end{array}$ & $44.45 \mathrm{~mm}$ & $\begin{array}{l}\text { Steel door, interior, } 1 \\
3 / 4 \text { in } \times 4 \times 8 \mathrm{ft}\end{array}$ & Total Door Systems & $1.759725 \mathrm{~m} 2$ \\
\hline $\begin{array}{l}\text { Frame: Hollow Metal, finish paint; } \\
\text { Door:Hollow Metal, finish paint }\end{array}$ & $\begin{array}{l}\text { Fleming Doors Products/ Daybar } \\
\text { Industries Limited/Steel-Craft } \\
\text { Door Products Ltd. }\end{array}$ & $\begin{array}{l}\text { Steel: ASTM A568/A568M, Class 1; Commercial } \\
\text { grade steel, hot dip galvanized to } \\
\text { ASTM A653/A653M, ZF120 galvanized coating. }\end{array}$ & $\begin{array}{l}081113 \\
\quad \text { D119 }\end{array}$ & $44.45 \mathrm{~mm}$ & $\begin{array}{l}\text { Steel door, interior, } 1 \\
3 / 4 \text { in } \times 4 \times 8 \mathrm{ft}\end{array}$ & Total Door Systems & $1.951695 \mathrm{~m} 2$ \\
\hline $\begin{array}{l}\text { Frame: Hollow Metal, finish paint; } \\
\text { Door:Hollow Metal, finish paint }\end{array}$ & $\begin{array}{l}\text { Fleming Doors Products/ Daybar } \\
\text { Industries Limited/ Steel-Craft } \\
\text { Door Products Ltd. }\end{array}$ & $\begin{array}{l}\text { Steel: ASTM A568/A568M, Class 1; Commercial } \\
\text { grade steel, hot dip galvanized to } \\
\text { ASTM A653/A653M, ZF120 galvanized coating. }\end{array}$ & $\begin{array}{l}081113 \\
\text { D120 }\end{array}$ & $44.45 \mathrm{~mm}$ & $\begin{array}{l}\text { Steel door, interior, } 1 \\
3 / 4 \text { in } \times 4 \times 8 \mathrm{ft}\end{array}$ & Total Door Systems & $1.759725 \mathrm{~m} 2$ \\
\hline $\begin{array}{l}\text { Frame: Hollow Metal, finish paint; } \\
\text { Door:Hollow Metal, finish paint }\end{array}$ & $\begin{array}{l}\text { Fleming Doors Products/ Daybar } \\
\text { Industries Limited/Steel-Craft } \\
\text { Door Products Ltd. }\end{array}$ & $\begin{array}{l}\text { Steel: ASTM A568/A568M, Class 1; Commercial } \\
\text { grade steel, hot dip galvanized to } \\
\text { ASTM A653/A653M, ZF120 galvanized coating. }\end{array}$ & $\begin{array}{l}081113 \\
\text { D121 }\end{array}$ & $44.45 \mathrm{~mm}$ & $\begin{array}{l}\begin{array}{l}\text { Steel door, interior, } 1 \\
3 / 4 \text { in } \times 4 \times 8 \mathrm{ft}\end{array}\end{array}$ & Total Door Systems & $1.759725 \mathrm{~m} 2$ \\
\hline $\begin{array}{l}\text { Frame: Hollow Metal, finish paint; } \\
\text { Door:Hollow Metal, finish paint }\end{array}$ & $\begin{array}{l}\text { Fleming Doors Products/ Daybar } \\
\text { Industries Limited/Steel-Craft } \\
\text { Door Products Ltd. }\end{array}$ & $\begin{array}{l}\text { Steel: ASTM A568/A568M, Class 1; Commercial } \\
\text { grade steel, hot dip galvanized to } \\
\text { ASTM A653/A653M, ZF120 galvanized coating. }\end{array}$ & $\begin{array}{ll}081113 \\
\text { D122 }\end{array}$ & $44.45 \mathrm{~mm}$ & $\begin{array}{l}\text { Steel door, interior, } 1 \\
3 / 4 \text { in } \times 4 \times 8 \mathrm{ft}\end{array}$ & Total Door Systems & $1.759725 \mathrm{~m} 2$ \\
\hline $\begin{array}{l}\text { Frame: Hollow Metal, finish paint; } \\
\text { Door:Hollow Metal, finish paint }\end{array}$ & $\begin{array}{l}\text { Fleming Doors Products/ Daybar } \\
\text { Industries Limited/Steel-Craft } \\
\text { Door Products Ltd. }\end{array}$ & $\begin{array}{l}\text { Steel: ASTM A568/A568M, Class 1; Commercial } \\
\text { grade steel, hot dip galvanized to } \\
\text { ASTM A653/A653M, ZF120 galvanized coating. }\end{array}$ & $\begin{array}{ll}081113 \\
\text { D123 }\end{array}$ & $44.45 \mathrm{~mm}$ & $\begin{array}{l}\text { Steel door, interior, } 1 \\
3 / 4 \text { in } \times 4 \times 8 \mathrm{ft}\end{array}$ & Total Door Systems & $1.759725 \mathrm{~m} 2$ \\
\hline $\begin{array}{l}\text { Frame: Hollow Metal, finish paint; } \\
\text { Door:Hollow Metal, finish paint }\end{array}$ & $\begin{array}{l}\text { Fleming Doors Products/ Daybar } \\
\text { Industries Limited/Steel-Craft } \\
\text { Door Products Ltd. }\end{array}$ & $\begin{array}{l}\text { Steel: ASTM A568/A568M, Class 1; Commercial } \\
\text { grade steel, hot dip galvanized to } \\
\text { ASTM A653/A653M, ZF120 galvanized coating. }\end{array}$ & $\begin{array}{l}081113 \\
\text { D124 }\end{array}$ & $44.45 \mathrm{~mm}$ & $\begin{array}{l}\text { Steel door, interior, } 1 \\
3 / 4 \text { in } \times 4 \times 8 \mathrm{ft}\end{array}$ & Total Door Systems & $1.759725 \mathrm{~m} 2$ \\
\hline $\begin{array}{l}\text { Frame: Hollow Metal, finish paint; } \\
\text { Door:Hollow Metal, finish paint }\end{array}$ & $\begin{array}{l}\text { Fleming Doors Products/ Daybar } \\
\text { Industries Limited/Steel-Craft } \\
\text { Door Products Ltd. }\end{array}$ & $\begin{array}{l}\text { Steel: ASTM A568/A568M, Class 1; Commercial } \\
\text { grade steel, hot dip galvanized to } \\
\text { ASTM A653/A653M, ZF120 galvanized coating. }\end{array}$ & $\begin{array}{ll}081113 \\
\text { D125 }\end{array}$ & $44.45 \mathrm{~mm}$ & $\mid \begin{array}{l}\text { Steel door, interior, } 1 \\
3 / 4 \text { in } \times 4 \times 8 f t\end{array}$ & Total Door Systems & $1.759725 \mathrm{~m} 2$ \\
\hline $\begin{array}{l}\text { Frame: Hollow Metal, finish paint; } \\
\text { Door:Hollow Metal, finish paint }\end{array}$ & $\begin{array}{l}\text { Fleming Doors Products/ Daybar } \\
\text { Industries Limited/Steel-Craft } \\
\text { Door Products Ltd. }\end{array}$ & $\begin{array}{l}\text { Steel: ASTM A568/A568M, Class 1; Commercial } \\
\text { grade steel, hot dip galvanized to } \\
\text { ASTM A653/A653M, ZF120 galvanized coating. }\end{array}$ & 081113 & $44.45 \mathrm{~mm}$ & $\begin{array}{l}\text { Steel door, interior, } 1 \\
3 / 4 \text { in } \times 4 \times 8 \mathrm{ft}\end{array}$ & Total Door Systems & $1.759725 \mathrm{~m} 2$ \\
\hline $\begin{array}{l}\text { Frame: Hollow Metal, finish paint; } \\
\text { Door:Hollow Metal, finish paint }\end{array}$ & $\begin{array}{l}\text { Fleming Doors Products/ Daybar } \\
\text { Industries Limited/Steel-Craft } \\
\text { Door Products Ltd. }\end{array}$ & $\begin{array}{l}\text { Steel: ASTM A568/A568M, Class 1; Commercial } \\
\text { grade steel, hot dip galvanized to } \\
\text { ASTM A653/A653M, ZF120 galvanized coating. }\end{array}$ & $\begin{array}{l}081113 \\
\text { D127 }\end{array}$ & $44.45 \mathrm{~mm}$ & $\begin{array}{l}\text { Steel door, interior, } 1 \\
3 / 4 \text { in } \times 4 \times 8 \mathrm{ft}\end{array}$ & Total Door Systems & $1.759725 \mathrm{~m} 2$ \\
\hline $\begin{array}{l}\text { Frame: Hollow Metal, finish paint; } \\
\text { Door:Hollow Metal, finish paint }\end{array}$ & $\begin{array}{l}\text { Fleming Doors Products/ Daybar } \\
\text { Industries Limited/Steel-Craft } \\
\text { Door Products Ltd. }\end{array}$ & $\begin{array}{l}\text { Steel: ASTM A568/A568M, Class 1; Commercial } \\
\text { grade steel, hot dip galvanized to } \\
\text { ASTM A653/A653M, ZF120 galvanized coating. }\end{array}$ & $\begin{array}{l}081113 \\
\quad \text { D128 }\end{array}$ & $44.45 \mathrm{~mm}$ & $\begin{array}{l}\text { Steel door, interior, } 1 \\
3 / 4 \text { in } \times 4 \times 8 \mathrm{ft}\end{array}$ & Total Door Systems & $1.951695 \mathrm{~m} 2$ \\
\hline $\begin{array}{l}\text { Frame: Hollow Metal, finish paint; } \\
\text { Door:Hollow Metal, finish paint }\end{array}$ & $\begin{array}{l}\text { Fleming Doors Products/ Daybar } \\
\text { Industries Limited/ Steel-Craft } \\
\text { Door Products Ltd. }\end{array}$ & $\begin{array}{l}\text { Steel: ASTM A568/A568M, Class 1; Commercial } \\
\text { grade steel, hot dip galvanized to } \\
\text { ASTM A653/A653M, ZF120 galvanized coating. }\end{array}$ & $\begin{array}{ll}081113 \\
\text { D129 }\end{array}$ & $44.45 \mathrm{~mm}$ & $\begin{array}{l}\text { Steel door, interior, } 1 \\
3 / 4 \text { in } \times 4 \times 8 \mathrm{ft}\end{array}$ & Total Door Systems & $1.759725 \mathrm{~m} 2$ \\
\hline $\begin{array}{l}\text { Frame: Hollow Metal, finish paint; } \\
\text { Door:Hollow Metal, finish paint }\end{array}$ & $\begin{array}{l}\text { Fleming Doors Products/ Daybar } \\
\text { Industries Limited/ Steel-Craft } \\
\text { Door Products Ltd. }\end{array}$ & $\begin{array}{l}\text { Steel: ASTM A568/A568M, Class 1; Commercial } \\
\text { grade steel, hot dip galvanized to } \\
\text { ASTM A653/A653M, ZF120 galvanized coating. }\end{array}$ & 081113 & $44.45 \mathrm{~mm}$ & $\mid \begin{array}{l}\begin{array}{l}\text { teeel door, interior, } 1 \\
3 / 4 \text { in } x 4 \times 8 f t\end{array} \\
\text {. }\end{array}$ & Total Door Systems & $1.759725 \mathrm{~m} 2$ \\
\hline
\end{tabular}




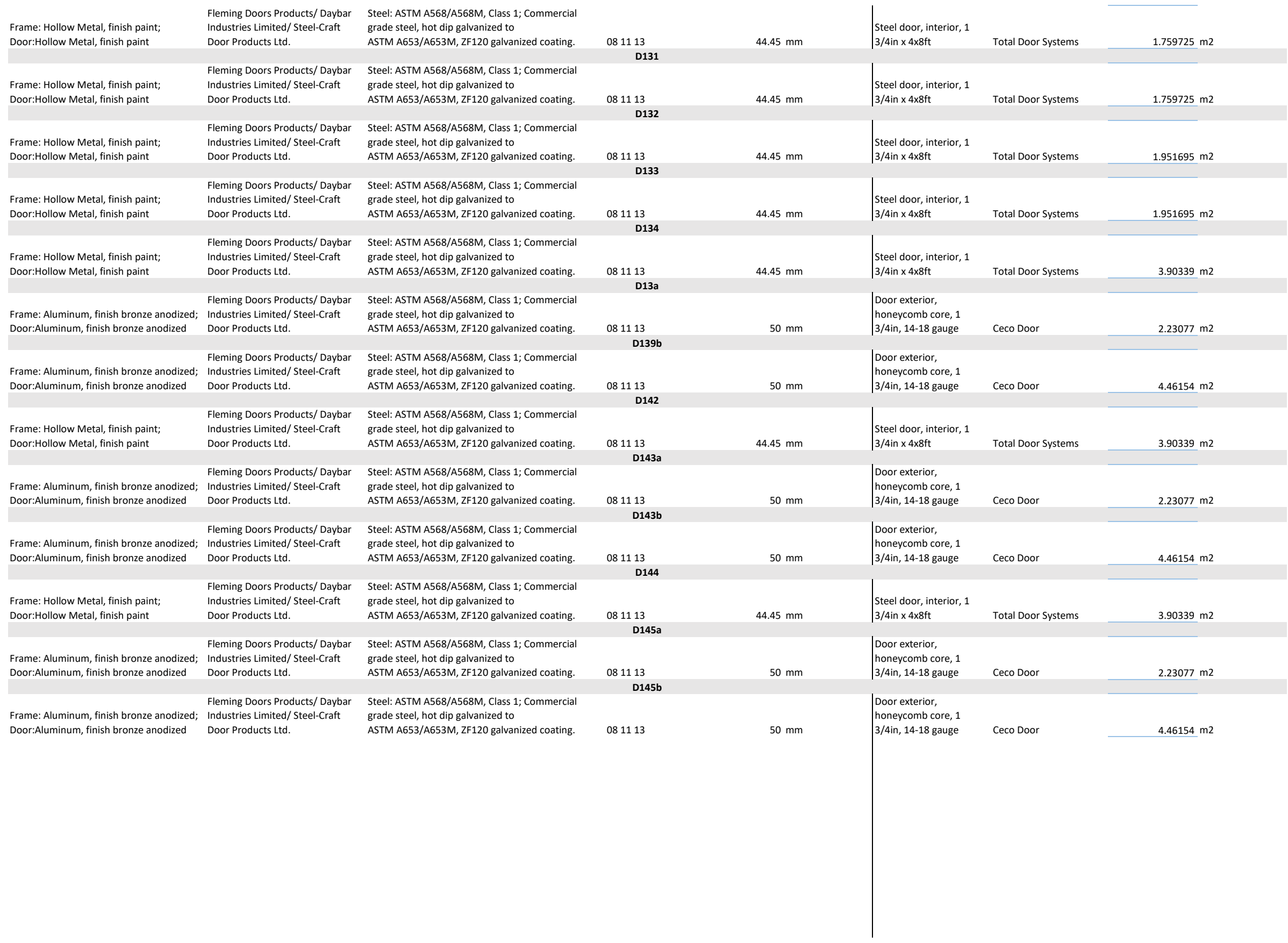




\section{Tally Results by Life Cycle Phase}

\begin{tabular}{lr} 
Row Labels & $\begin{array}{c}\text { Sum of Global Warming } \\
\text { Potential Total (kgCO2eq) }\end{array}$ \\
\hline End of Life & -374.30 \\
Maintenance and & \\
Replacement & $257,193.97$ \\
Manufacturing & $1,102,383.13$ \\
Operational Energy & $16,789,158.68$ \\
Transportation & $17,972.48$ \\
\hline Grand Total & $\mathbf{1 8 , 1 6 6 , 3 3 3 . 9 6}$
\end{tabular}


Tally Results by Material

\begin{tabular}{lr} 
& \multicolumn{2}{c}{ Sum of Global Warming Potential Total } \\
Row Labels & (kgCO2eq) \\
\hline $\mathbf{0 3}$ - Concrete & $\mathbf{6 9 5 , 6 8 2 . 1 5}$ \\
\hline Air-entrained structural concrete; unreinforced & $582,103.84$ \\
Cast-in-place concrete; slab on grade & $7,131.35$ \\
& \\
Concrete; unreinforced; generic; 3000 psi (20MPa) & $105,730.88$ \\
Reinforced slab; exclusive of deck & 716.09 \\
04 - Masonry & $\mathbf{3 7 , 9 7 7 . 6 8}$ \\
\hline Brick; generic; grouted & $5,996.03$ \\
Hollow-core CMU; grouted & $31,981.65$ \\
05 - Metals & $\mathbf{1 2 3 , 5 3 5 . 1 4}$ \\
\hline Aluminum; sheet & 923.56 \\
Steel; C-stud metal framing with insulation & $4,065.17$ \\
Steel; form deck & $3,358.03$ \\
Steel; furring channel & 119.62 \\
Steel; roof decking & $115,068.76$ \\
06 - Wood/Plastics/Composites & $\mathbf{1 1 , 5 4 2 . 0 3}$ \\
\hline Cement bonded particle board & $10,933.86$ \\
Fiberglass mat gypsum sheathing & 608.17 \\
07 - Thermal and Moisture Protection & $\mathbf{3 3 5 , 8 3 4 . 4 1}$ \\
\hline Expanded polystyrene (EPS); board & 121.40 \\
Extruded polystyrene (XPS); board & 881.74 \\
Mineral wool; board; generic & $2,509.94$ \\
Open cell; polyurethane foam; spray-applied & 488.22 \\
Polyethelene sheet vapor barrier (HDPE) & $8,524.99$ \\
Polyisocyanurate (PIR); board & $322,538.82$ \\
Self adhering membrane & 431.53 \\
Self-adhering sheet waterproofing; modified bituminous & \\
sheet & 337.78 \\
08 - Openings and Glazing & $\mathbf{1 3 4 , 3 5 9 . 4 6}$ \\
\hline Aluminum mullion; anodized & $14,140.75$ \\
Door; exterior; aluminum & $23,649.35$ \\
& \\
\hline
\end{tabular}


Glazing; double pane IGU

$38,768.03$

Glazing; monolithic sheet

$6,474.23$

Spandrel; aluminum; insulated

$45,131.65$

336.88

Window frame; aluminum

$\mathbf{3 8 , 2 4 4 . 4 0}$

09 - Finishes

$36,701.35$

Ceramic tile; unglazed

419.05

Fiberglass mat gypsum sheathing

$1,124.00$

Wall board; gypsum

$\mathbf{1 6 , 7 8 9 , 1 5 8 . 6 8}$

Operational Electricity

$16,789,158.68$

Operational Electricity

0.00

Operational Heating

Grand Total

$18,166,333.96$ 
Athena Impact Estimator - Results by Building Component

\begin{tabular}{|c|c|c|c|c|c|c|}
\hline LCA Measures & Unit & Walls & Roofs & Floors & $\begin{array}{c}\text { Project Extra } \\
\text { Materials }\end{array}$ & Total \\
\hline Global Warming Potential & $\mathrm{kg} \mathrm{CO} 2 \mathrm{eq}$ & $6.19 \mathrm{E}+04$ & $2.69 \mathrm{E}+05$ & $4.75 \mathrm{E}+05$ & $8.70 \mathrm{E}+04$ & $\mathbf{8 . 9 3 E + 0 5}$ \\
\hline
\end{tabular}


Athena Impact Estimator - Results by Life Cycle Phase

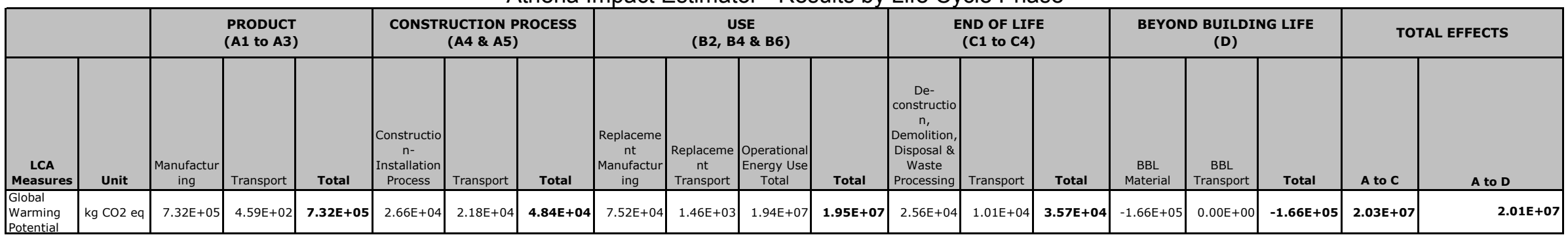


One-Click LCA Results - Construction Materials

\begin{tabular}{|l|l|l|l|}
\hline Resource & User input & $\begin{array}{l}\text { Global warming } \\
\mathrm{kg} \mathrm{CO} \text { CO }\end{array}$ & Comments \\
\hline
\end{tabular}

\section{External wall}

Concrete masonry unit (CMU), 7 7/8inx7

5/8inx15 5/8in, HW Re..

Steel framing systems, Studrite, Joistrite,

Framerite, Viper...

Steel framing systems, Studrite, Joistrite,

Framerite, Viper...

Insulated metal panel, $13 / 4 \mathrm{in}-4 \mathrm{in} \times 36 \mathrm{inx6}$ -

48ft, Versapanel (...

Mineral wool insulation batt, R11, EcoBatt

Insulation with $\mathrm{E}$...

Mineral wool insulation batt, R11, EcoBatt

Insulation with E...

XPS insulation (extruded polystyrene),

1.02in

$8.8 \mathrm{~m} 3$
$90.18 \mathrm{~kg}$
$456.3 \mathrm{~kg}$

XPS insulation (extruded polystyrene),

1.02in

$10.45 \mathrm{~m} 3$

$19.27 \mathrm{~m} 2$

$97.79 \mathrm{~m} 2$

Roll formed steel panels, 24 gauge, 5.9

$\mathrm{kg} / \mathrm{m} 2$ (CSSBI)

Gypsum Board Type X, 5/8", 2.25 psf

(CertainTeed Toronto Fac...

Gypsum Board Type X, 5/8", 2.25 psf

(CertainTeed Toronto Fac...

Vapor barrier, 0.06in

Vapor barrier, 0.06in

$19.27 \mathrm{~m} 2$

$97.79 \mathrm{~m} 2$

Medium density fiberboard (MDF), 0.75in

(Canadian Wood Counc...

Medium density fiberboard (MDF), 0.75in

(Canadian Wood Counc.

\begin{tabular}{|c|c|}
\hline $3,185.60$ & W3 \\
\hline 217.33 & W4 \\
\hline $1,099.68$ & w3 \\
\hline $9,048.82$ & W2 \\
\hline 1.88 & W4 \\
\hline 9.53 & W3 \\
\hline 622.25 & W4 \\
\hline $3,157.56$ & w3 \\
\hline 288.03 & W4 \\
\hline 60.16 & W4 \\
\hline 305.26 & w3 \\
\hline 14.39 & |W4 \\
\hline 73.01 & |w3 \\
\hline 96.31 & W4 \\
\hline 488.74 & w3 \\
\hline
\end{tabular}

\section{Partition Wall}

\begin{tabular}{|l|l|l|l|}
\hline Concrete masonry unit & $12.48 \mathrm{~m} 3$ & $5,447.57$ & P2 \\
|Concrete masonry unit & $12.92 \mathrm{~m} 3$ & $5,640.51$ & P3 \\
|Concrete masonry unit & $13.36 \mathrm{m3}$ & $5,829.95$ & P1 \\
Concrete masonry unit & $14.91 \mathrm{~m} 3$ & $\mid 6,508.28$ & P5
\end{tabular}




\begin{tabular}{|c|c|c|c|}
\hline Concrete masonry unit & $23.99 \mathrm{~m} 3$ & $\mid 10,471.73$ & P4 \\
\hline $\begin{array}{l}\text { Bio-based tile flooring, } 12 \times 12,12 \times 24 \text { in, } \\
0.125 \mathrm{in}, 1.44 \mathrm{lbs} / . \ldots\end{array}$ & $95.4 \mathrm{~m} 2$ & 437.88 & P1 \\
\hline $\begin{array}{l}\text { Bio-based tile flooring, } 12 \times 12,12 \times 24 \text { in, } \\
0.125 \text { in, } 1.44 \text { lbs/... }\end{array}$ & $171.35 \mathrm{~m} 2$ & 786.49 & P4 \\
\hline $\begin{array}{l}\text { Bio-based tile flooring, } 12 \times 12,12 \times 24 \text { in, } \\
0.125 \text { in, } 1.44 \text { lbs/... }\end{array}$ & $298.2 \mathrm{~m} 2$ & $1,368.74$ & P5 \\
\hline $\begin{array}{l}\text { Steel framing systems, Studrite, Joistrite, } \\
\text { Framerite, Viper... }\end{array}$ & $9.56 \mathrm{~kg}$ & 23.04 & P2 resilient channel \\
\hline $\begin{array}{l}\text { Steel framing systems, Studrite, Joistrite, } \\
\text { Framerite, Viper... }\end{array}$ & $9.68 \mathrm{~kg}$ & 23.33 & P1 resilient channel \\
\hline $\begin{array}{l}\text { Steel framing systems, Studrite, Joistrite, } \\
\text { Framerite, Viper... }\end{array}$ & $14.22 \mathrm{~kg}$ & 34.27 & P3 resilient channel \\
\hline $\begin{array}{l}\text { Steel framing systems, Studrite, Joistrite, } \\
\text { Framerite, Viper... }\end{array}$ & $17.89 \mathrm{~kg}$ & 43.11 & P3 Furring channel \\
\hline $\begin{array}{l}\text { Pressed glass partition, } 0.236 \mathrm{in}, 152.3 \\
\text { |bs/ft3, InfinteGlas... }\end{array}$ & $171.35 \mathrm{~m} 2$ & 6.56 & P4 \\
\hline $\begin{array}{l}\text { Mineral wool insulation batt, R11, EcoBatt } \\
\text { Insulation with E... }\end{array}$ & $89.12 \mathrm{~m} 2$ & 3.72 & P2 \\
\hline $\begin{array}{l}\text { Mineral wool insulation batt, R11, EcoBatt } \\
\text { Insulation with E... }\end{array}$ & $95.4 \mathrm{~m} 2$ & 3.98 & P1 \\
\hline $\begin{array}{l}\text { Mineral wool insulation batt, R11, EcoBatt } \\
\text { Insulation with E... }\end{array}$ & 171.35 m2 & 7.16 & P4 \\
\hline $\begin{array}{l}\text { Rebar, hot-rolled, Knoxville mill, } 490 \text { lbs/ft3 } \\
\text { (Gerdau) }\end{array}$ & $55.46 \mathrm{~kg}$ & 36.73 & P3 \\
\hline $\begin{array}{l}\text { Rebar, hot-rolled, Knoxville mill, } 490 \text { lbs/ft3 } \\
\text { (Gerdau) }\end{array}$ & $72.66 \mathrm{~kg}$ & 48.12 & P2 \\
\hline $\begin{array}{l}\text { Rebar, hot-rolled, Knoxville mill, } 490 \text { lbs/ft3 } \\
\text { (Gerdau) }\end{array}$ & $77.78 \mathrm{~kg}$ & 51.51 & P1 \\
\hline $\begin{array}{l}\text { Rebar, hot-rolled, Knoxville mill, } 490 \text { lbs/ft3 } \\
\text { (Gerdau) }\end{array}$ & $121.6 \mathrm{~kg}$ & 80.52 & P5 \\
\hline $\begin{array}{l}\text { Rebar, hot-rolled, Knoxville mill, } 490 \text { lbs/ft3 } \\
\text { (Gerdau) }\end{array}$ & $139.7 \mathrm{~kg}$ & 92.51 & P4 \\
\hline $\begin{array}{l}\text { Medium density fiberboard (MDF), } 0.75 \text { in } \\
\text { (Canadian Wood Counc... }\end{array}$ & $89.12 \mathrm{~m} 2$ & 445.39 & P2 \\
\hline $\begin{array}{l}\text { Medium density fiberboard (MDF), } 0.75 \text { in } \\
\text { (Canadian Wood Counc... }\end{array}$ & $95.4 \mathrm{~m} 2$ & 476.78 & $\mathrm{P} 1$ \\
\hline $\begin{array}{l}\text { Medium density fiberboard (MDF), 0.75in } \\
\text { (Canadian Wood Counc... }\end{array}$ & $171.35 \mathrm{~m} 2$ & 856.37 & P4 \\
\hline $\begin{array}{l}\text { Medium density fiberboard (MDF), } 0.75 \text { in } \\
\text { (Canadian Wood Counc... }\end{array}$ & 171.35 m2 & 856.37 & P4 \\
\hline
\end{tabular}


Floor and roof

\begin{tabular}{|c|c|c|c|}
\hline Fluid-applied rubber asphalt roofing, 0.17 in & $80.69 \mathrm{~m} 2$ & 276.12 & R2 \\
\hline $\begin{array}{l}\text { Ready-mix concrete, } 25 \mathrm{MPa} \text { GU cem. cem. } \\
\text { with air entr. } 0-14 \% \ldots\end{array}$ & $7.6 \mathrm{~m} 3$ & $2,487.71$ & F6 \\
\hline $\begin{array}{l}\text { Ready-mix concrete, } 25 \mathrm{MPa} \text { GU cem. cem. } \\
\text { with air entr. } 0-14 \% \ldots\end{array}$ & $9.32 \mathrm{~m} 3$ & $3,052.35$ & C3 \\
\hline $\begin{array}{l}\text { Ready-mix concrete, } 25 \mathrm{MPa} \text { GU cem. cem. } \\
\text { with air entr. } 0-14 \% \ldots\end{array}$ & $11.25 \mathrm{~m} 3$ & $3,682.46$ & F8 \\
\hline $\begin{array}{l}\text { Ready-mix concrete, } 25 \mathrm{MPa} \text { GU cem. cem. } \\
\text { with air entr. } 0-14 \% \ldots\end{array}$ & $15.6 \mathrm{~m} 3$ & $5,106.35$ & $F 2$ \\
\hline $\begin{array}{l}\text { Ready-mix concrete, } 25 \mathrm{MPa} \text { GU cem. cem. } \\
\text { with air entr. } 0-14 \% \ldots\end{array}$ & $78 \mathrm{~m} 3$ & $25,531.74$ & F2 \\
\hline $\begin{array}{l}\text { Ready-mix concrete, } 25 \mathrm{MPa} \text { GU cem. cem. } \\
\text { with air entr. } 0-14 \% \ldots\end{array}$ & $180.53 \mathrm{~m} 3$ & $59,092.88$ & $\mathrm{~F} 1$ \\
\hline $\begin{array}{l}\text { Ready-mix concrete, } 25 \mathrm{MPa} \text { GU cem. cem. } \\
\text { with air entr. } 0-14 \% \ldots\end{array}$ & $305.69 \mathrm{~m} 3$ & $100,061.51$ & F1 \\
\hline $\begin{array}{l}\text { Ready-mix concrete, } 25 \mathrm{MPa} \text { GU cem. cem. } \\
\text { with air entr. } 0-14 \% \ldots\end{array}$ & $601.75 \mathrm{~m} 3$ & $196,970.83$ & F1 \\
\hline $\begin{array}{l}\text { Steel framing systems, Studrite, Joistrite, } \\
\text { Framerite, Viper... }\end{array}$ & $14.45 \mathrm{~kg}$ & 34.82 & C2 resilient channels \\
\hline $\begin{array}{l}\text { Steel framing systems, Studrite, Joistrite, } \\
\text { Framerite, Viper... }\end{array}$ & $176 \mathrm{~kg}$ & 424.16 & C2 \\
\hline $\begin{array}{l}\text { Gypsum board, wallboard, regular, } 0.5 \text { inch } \\
(12.7 \mathrm{~mm})\end{array}$ & $129.84 \mathrm{~m} 2$ & 326.24 & $\mathrm{C} 2$ \\
\hline $\begin{array}{l}\text { Mineral wool insulation batt, R11, EcoBatt } \\
\text { Insulation with E... }\end{array}$ & $129.84 \mathrm{~m} 2$ & 12.65 & C2 \\
\hline $\begin{array}{l}\text { ISO foam insulation, } 0.5-2 \text { in, Tuff-R } \\
\text { Insulation (Dow) }\end{array}$ & $5,276 \mathrm{~m} 2$ & $72,610.09$ & R1 \\
\hline Spray foam insulation, 1.02in & $80.69 \mathrm{~m} 2$ & 7,787.05 & R2 \\
\hline Composite metal decking, 30 mil & $80.69 \mathrm{~m} 2$ & 1,254.91 & R2 \\
\hline $\begin{array}{l}\text { Rebar, hot-rolled, Knoxville mill, } 490 \text { lbs/ft3 } \\
\text { (Gerdau) }\end{array}$ & $54.24 \mathrm{~kg}$ & 35.92 & C3 \\
\hline $\begin{array}{l}\text { Rebar, hot-rolled, Knoxville mill, } 490 \text { lbs/ft3 } \\
\text { (Gerdau) }\end{array}$ & $982.7 \mathrm{~kg}$ & 650.74 & F8 \\
\hline $\begin{array}{l}\text { Steel roof and floor deck, 22-16 gauge } \\
\text { (Steel Deck Institute... }\end{array}$ & $320 \mathrm{~kg}$ & 758.4 & C3 \\
\hline $\begin{array}{l}\text { Steel roof and floor deck, } 22-16 \text { gauge } \\
\text { (Steel Deck Institute... }\end{array}$ & $443.2 \mathrm{~kg}$ & $1,050.38$ & F6 \\
\hline
\end{tabular}




\begin{tabular}{|c|c|c|c|}
\hline $\begin{array}{l}\text { Steel roof and floor deck, 22-16 gauge } \\
\text { (Steel Deck Institute... }\end{array}$ & $668 \mathrm{~kg}$ & $1,583.16$ & $\mathrm{C} 2$ \\
\hline $\begin{array}{l}\text { Steel roof and floor deck, 22-16 gauge } \\
\text { (Steel Deck Institute... }\end{array}$ & $63,314 \mathrm{~kg}$ & $150,054.18$ & R1 \\
\hline $\begin{array}{l}\text { Gypsum Board Type X, 5/8", } 2.25 \text { psf } \\
\text { (CertainTeed Toronto Fac... }\end{array}$ & $80.69 \mathrm{~m} 2$ & 251.88 & R2 \\
\hline Vapor barrier, 0.06in & $5,276 \mathrm{~m} 2$ & $3,938.88$ & R1 \\
\hline $\begin{array}{l}\text { Medium density fiberboard (MDF), } 0.75 \text { in } \\
\text { (Canadian Wood Counc... }\end{array}$ & $80.69 \mathrm{~m} 2$ & 403.27 & R2 \\
\hline
\end{tabular}

\section{Windows and doors}

\begin{tabular}{|l|l|l|l|}
\hline $\begin{array}{l}\text { Aluminum window, fixed and ribbon, } 1.2 \mathrm{~m} \times \\
1.5 \mathrm{~m}, 24.8 \mathrm{~kg} / \text { piec... }\end{array}$ & $18.06 \mathrm{~m} 2$ & $7,730.11$ & \\
\hline $\begin{array}{l}\text { Steel door, interior, } 13 / 4 \mathrm{in} \times 4 \times 8 \mathrm{ft}(\text { Total } \\
\text { Door Systems) }\end{array}$ & $55.1 \mathrm{~m} 2$ & $6,842.94$ & \\
\begin{tabular}{|l|l|l|} 
Door, exterior, Honeycomb core, $13 / 4 \mathrm{in}, 14$ \\
18 gauge, $48.42 \mathrm{x} \ldots$
\end{tabular} & $66.74 \mathrm{~m} 2$ & $2,814.16$ & \\
\hline $\begin{array}{l}\text { Traditional curtain wall, } 1.5 \mathrm{~m} \times 1.6 \mathrm{~m}, 35.6 \\
\text { kg/piece, } 16001 \ldots\end{array}$ & $523.9 \mathrm{~m} 2$ & $10,404.65$ & \\
\hline
\end{tabular}


One-Click LCA Results - Transportation Phase

\begin{tabular}{|c|c|c|c|}
\hline Resource & User input & $\begin{array}{l}\text { Global warming } \\
\mathrm{kg} \mathrm{CO} 2 \mathrm{e}\end{array}$ & Comments \\
\hline \multicolumn{4}{|l|}{ External wall } \\
\hline $\begin{array}{l}\text { Concrete masonry unit (CMU), } 7 \\
\text { 7/8inx7 5/8inx15 5/8in, HW Re... }\end{array}$ & $8.8 \mathrm{~m} 3$ & 99.85 & W3 \\
\hline $\begin{array}{l}\text { Steel framing systems, Studrite, } \\
\text { Joistrite, Framerite, Viper... }\end{array}$ & $90.18 \mathrm{~kg}$ & 3.58 & W4 \\
\hline $\begin{array}{l}\text { Steel framing systems, Studrite, } \\
\text { Joistrite, Framerite, Viper... }\end{array}$ & $456.3 \mathrm{~kg}$ & 18.1 & w3 \\
\hline $\begin{array}{l}\text { Insulated metal panel, } 13 / 4 \mathrm{in}- \\
\text { 4inx36inx6-48ft, Versapanel (... }\end{array}$ & $10.45 \mathrm{~m} 3$ & 34.96 & w2 \\
\hline $\begin{array}{l}\text { Mineral wool insulation batt, R11, } \\
\text { EcoBatt Insulation with E... }\end{array}$ & $19.27 \mathrm{~m} 2$ & 0.85 & W4 \\
\hline $\begin{array}{l}\text { Mineral wool insulation batt, R11, } \\
\text { EcoBatt Insulation with E... }\end{array}$ & $97.79 \mathrm{~m} 2$ & 4.33 & w3 \\
\hline $\begin{array}{l}\text { XPS insulation (extruded } \\
\text { polystyrene), 1.02in }\end{array}$ & $19.27 \mathrm{~m} 2$ & 0.39 & W4 \\
\hline $\begin{array}{l}\text { XPS insulation (extruded } \\
\text { polystyrene), 1.02in }\end{array}$ & $97.79 \mathrm{~m} 2$ & 1.98 & W3 \\
\hline $\begin{array}{l}\text { Roll formed steel panels, } 24 \\
\text { gauge, } 5.9 \mathrm{~kg} / \mathrm{m} 2 \text { (CSSBI) }\end{array}$ & $19.27 \mathrm{~m} 2$ & 1.53 & W4 \\
\hline $\begin{array}{l}\text { Gypsum Board Type X, 5/8", } 2.25 \\
\text { psf (CertainTeed Toronto Fac... }\end{array}$ & $19.27 \mathrm{~m} 2$ & 1.67 & W4 \\
\hline $\begin{array}{l}\text { Gypsum Board Type X, 5/8", } 2.25 \\
\text { psf (CertainTeed Toronto Fac... }\end{array}$ & $97.79 \mathrm{~m} 2$ & 8.48 & w3 \\
\hline Vapor barrier, 0.06in & $19.27 \mathrm{~m} 2$ & 0.15 & |w4 \\
\hline Vapor barrier, 0.06in & $97.79 \mathrm{~m} 2$ & 0.78 & W3 \\
\hline $\begin{array}{l}\text { Medium density fiberboard (MDF), } \\
0.75 \text { in (Canadian Wood Counc... }\end{array}$ & $19.27 \mathrm{~m} 2$ & 1.28 & W4 \\
\hline
\end{tabular}


\begin{tabular}{l|l} 
Medium density fiberboard (MDF), & $97.79 \mathrm{~m} 2$ \\
0.75in (Canadian Wood Counc... &
\end{tabular}

6.51

W3

\section{Parition}

\begin{tabular}{|c|c|c|c|}
\hline Concrete masonry unit & $12.48 \mathrm{~m} 3$ & 141.58 & P2 \\
\hline Concrete masonry unit & $12.92 \mathrm{~m} 3$ & 146.59 & P3 \\
\hline Concrete masonry unit & 13.36 m3 & 151.52 & P1 \\
\hline Concrete masonry unit & $14.91 \mathrm{~m} 3$ & |169.14 & P5 \\
\hline Concrete masonry unit & $23.99 \mathrm{~m} 3$ & 272.15 & P4 \\
\hline $\begin{array}{l}\text { Bio-based tile flooring, } 12 \times 12 \text {, } \\
12 \times 24 \mathrm{in}, 0.125 \mathrm{in}, 1.44 \mathrm{lbs} / \ldots\end{array}$ & $95.4 \mathrm{~m} 2$ & 5.22 & P1 \\
\hline $\begin{array}{l}\text { Bio-based tile flooring, } 12 \times 12 \\
12 \times 24 \text { in, } 0.125 \text { in, } 1.44 \mathrm{lbs} / \ldots\end{array}$ & $171.35 \mathrm{~m} 2$ & 9.38 & P4 \\
\hline $\begin{array}{l}\text { Bio-based tile flooring, } 12 \times 12 \text {, } \\
12 \times 24 \mathrm{in}, 0.125 \mathrm{in}, 1.44 \mathrm{lbs} / \ldots\end{array}$ & $298.2 \mathrm{~m} 2$ & 16.33 & P5 \\
\hline $\begin{array}{l}\text { Steel framing systems, Studrite, } \\
\text { Joistrite, Framerite, Viper... }\end{array}$ & $9.56 \mathrm{~kg}$ & 0.38 & P2 resilient channel \\
\hline $\begin{array}{l}\text { Steel framing systems, Studrite, } \\
\text { Joistrite, Framerite, Viper... }\end{array}$ & $9.68 \mathrm{~kg}$ & 0.38 & P1 resilient channel \\
\hline $\begin{array}{l}\text { Steel framing systems, Studrite, } \\
\text { Joistrite, Framerite, Viper... }\end{array}$ & $14.22 \mathrm{~kg}$ & 0.56 & P3 resilient channel \\
\hline $\begin{array}{l}\text { Steel framing systems, Studrite, } \\
\text { Joistrite, Framerite, Viper... }\end{array}$ & $17.89 \mathrm{~kg}$ & 0.71 & P3 Furring channel \\
\hline $\begin{array}{l}\text { Pressed glass partition, } 0.236 \mathrm{in}, \\
152.3 \mathrm{lbs} / \mathrm{ft} 3 \text {, InfinteGlas... }\end{array}$ & $171.35 \mathrm{~m} 2$ & 192.11 & P4 \\
\hline $\begin{array}{l}\text { Mineral wool insulation batt, R11, } \\
\text { EcoBatt Insulation with E... }\end{array}$ & $89.12 \mathrm{~m} 2$ & 1.69 & P2 \\
\hline $\begin{array}{l}\text { Mineral wool insulation batt, R11, } \\
\text { EcoBatt Insulation with E... }\end{array}$ & $95.4 \mathrm{~m} 2$ & 1.81 & P1 \\
\hline $\begin{array}{l}\text { Mineral wool insulation batt, R11, } \\
\text { EcoBatt Insulation with E... }\end{array}$ & $171.35 \mathrm{~m} 2$ & 3.25 & P4 \\
\hline
\end{tabular}




\begin{tabular}{|l|l|l|l|}
\hline $\begin{array}{l}\text { Rebar, hot-rolled, Knoxville mill, } \\
490 \text { lbs/ft3 (Gerdau) }\end{array}$ & $55.46 \mathrm{~kg}$ & 2.2 & $\mathrm{P} 3$ \\
\hline $\begin{array}{l}\text { Rebar, hot-rolled, Knoxville mill, } \\
\text { 490 lbs/ft3 (Gerdau) }\end{array}$ & $72.66 \mathrm{~kg}$ & 2.88 & $\mathrm{P} 2$ \\
\hline $\begin{array}{l}\text { Rebar, hot-rolled, Knoxville mill, } \\
490 \mathrm{lbs} / \mathrm{ft} 3 \text { (Gerdau) }\end{array}$ & $77.78 \mathrm{~kg}$ & 3.08 & $\mathrm{P} 1$ \\
\hline $\begin{array}{l}\text { Rebar, hot-rolled, Knoxville mill, } \\
490 \mathrm{lbs} / \mathrm{ft} 3 \text { (Gerdau) }\end{array}$ & $121.6 \mathrm{~kg}$ & 4.82 & $\mathrm{P} 5$ \\
\hline $\begin{array}{l}\text { Rebar, hot-rolled, Knoxville mill, } \\
490 \mathrm{lbs} / \mathrm{ft} 3 \text { (Gerdau) }\end{array}$ & $139.7 \mathrm{~kg}$ & 5.54 & $\mathrm{P} 4$ \\
\hline $\begin{array}{l}\text { Medium density fiberboard (MDF), } \\
0.75 \text { in (Canadian Wood Counc... }\end{array}$ & $89.12 \mathrm{~m} 2$ & 5.93 & $\mathrm{P} 2$ \\
\hline $\begin{array}{l}\text { Medium density fiberboard (MDF), } \\
0.75 \text { in (Canadian Wood Counc... }\end{array}$ & $95.4 \mathrm{~m} 2$ & 6.35 & $\mathrm{P} 1$ \\
\hline $\begin{array}{l}\text { Medium density fiberboard (MDF), } \\
0.75 \text { in (Canadian Wood Counc... }\end{array}$ & $171.35 \mathrm{~m} 2$ & 11.41 & $\mathrm{P} 4$ \\
\hline $\begin{array}{l}\text { Medium density fiberboard (MDF), } \\
0.75 \text { in (Canadian Wood Counc... }\end{array}$ & $171.35 \mathrm{~m} 2$ & 11.41 & $\mathrm{P} 4$ \\
\hline
\end{tabular}

\section{Floors and roof}

\begin{tabular}{|l|l|l|l|}
\hline $\begin{array}{l}\text { Fluid-applied rubber asphalt } \\
\text { roofing, 0.17in }\end{array}$ & $80.69 \mathrm{~m} 2$ & 18.21 & R2 \\
\hline $\begin{array}{l}\text { Ready-mix concrete, 25MPa GU } \\
\text { cem. cem. with air entr. 0-14\% ... }\end{array}$ & $7.6 \mathrm{~m} 3$ & 276.96 & $\mathrm{~F} 6$ \\
\hline $\begin{array}{l}\text { Ready-mix concrete, 25MPa GU } \\
\text { cem. cem. with air entr. 0-14\% ... }\end{array}$ & $9.32 \mathrm{~m} 3$ & 339.82 & $\mathrm{C} 3$ \\
\hline $\begin{array}{l}\text { Ready-mix concrete, 25MPa GU } \\
\text { cem. cem. with air entr. 0-14\% ... }\end{array}$ & $11.25 \mathrm{~m} 3$ & 409.97 & $\mathrm{~F} 8$ \\
\hline $\begin{array}{l}\text { Ready-mix concrete, 25MPa GU } \\
\text { cem. cem. with air entr. 0-14\% ... }\end{array}$ & $15.6 \mathrm{~m} 3$ & 568.49 & $\mathrm{~F} 2$ \\
\hline $\begin{array}{l}\text { Ready-mix concrete, 25MPa GU } \\
\text { cem. cem. with air entr. 0-14\% ... }\end{array}$ & $78 \mathrm{~m} 3$ & $2,842.44$ & $\mathrm{~F} 2$ \\
\hline
\end{tabular}




\begin{tabular}{|c|c|c|c|}
\hline $\begin{array}{l}\text { Ready-mix concrete, } 25 \mathrm{MPa} \text { GU } \\
\text { cem. cem. with air entr. } 0-14 \% \ldots\end{array}$ & $180.53 \mathrm{~m} 3$ & $6,578.80$ & F1 \\
\hline $\begin{array}{l}\text { Ready-mix concrete, } 25 \mathrm{MPa} \text { GU } \\
\text { cem. cem. with air entr. } 0-14 \% \ldots\end{array}$ & $305.69 \mathrm{~m} 3$ & $11,139.83$ & F1 \\
\hline $\begin{array}{l}\text { Ready-mix concrete, } 25 \mathrm{MPa} \text { GU } \\
\text { cem. cem. with air entr. } 0-14 \% \ldots\end{array}$ & $601.75 \mathrm{~m} 3$ & $21,928.73$ & F1 \\
\hline $\begin{array}{l}\text { Steel framing systems, Studrite, } \\
\text { Joistrite, Framerite, Viper... }\end{array}$ & $14.45 \mathrm{~kg}$ & 0.57 & C2 resilient channels \\
\hline $\begin{array}{l}\text { Steel framing systems, Studrite, } \\
\text { Joistrite, Framerite, Viper... }\end{array}$ & 176 kg & 6.98 & $\mathrm{C} 2$ \\
\hline $\begin{array}{l}\text { Gypsum board, wallboard, regular, } \\
0.5 \text { inch }(12.7 \mathrm{~mm})\end{array}$ & $129.84 \mathrm{~m} 2$ & 7.73 & C2 \\
\hline $\begin{array}{l}\text { Mineral wool insulation batt, R11, } \\
\text { EcoBatt Insulation with E... }\end{array}$ & $129.84 \mathrm{~m} 2$ & 5.75 & C2 \\
\hline $\begin{array}{l}\text { ISO foam insulation, } 0.5 \text {-2in, Tuff- } \\
\text { R Insulation (Dow) }\end{array}$ & $5,276 \mathrm{~m} 2$ & 200.44 & R1 \\
\hline Spray foam insulation, 1.02in & $80.69 \mathrm{~m} 2$ & 39.39 & |R2 \\
\hline Composite metal decking, 30 mil & $80.69 \mathrm{~m} 2$ & 18.71 & R2 \\
\hline $\begin{array}{l}\text { Rebar, hot-rolled, Knoxville mill, } \\
490 \text { lbs/ft3 (Gerdau) }\end{array}$ & $54.24 \mathrm{~kg}$ & 2.15 & C3 \\
\hline $\begin{array}{l}\text { Rebar, hot-rolled, Knoxville mill, } \\
490 \text { lbs/ft3 (Gerdau) }\end{array}$ & $982.7 \mathrm{~kg}$ & 38.97 & F8 \\
\hline $\begin{array}{l}\text { Steel roof and floor deck, 22-16 } \\
\text { gauge (Steel Deck Institute... }\end{array}$ & $320 \mathrm{~kg}$ & 12.69 & C3 \\
\hline $\begin{array}{l}\text { Steel roof and floor deck, 22-16 } \\
\text { gauge (Steel Deck Institute... }\end{array}$ & $443.2 \mathrm{~kg}$ & 17.58 & F6 \\
\hline $\begin{array}{l}\text { Steel roof and floor deck, 22-16 } \\
\text { gauge (Steel Deck Institute... }\end{array}$ & $668 \mathrm{~kg}$ & 26.49 & C2 \\
\hline $\begin{array}{l}\text { Steel roof and floor deck, 22-16 } \\
\text { gauge (Steel Deck Institute... }\end{array}$ & 63,314 kg & 2,511 & R1 \\
\hline
\end{tabular}




\begin{tabular}{|l|l|l|l|}
\begin{tabular}{|l|l|l|} 
Gypsum Board Type X, 5/8", 2.25 \\
psf (CertainTeed Toronto Fac...
\end{tabular} & $80.69 \mathrm{~m} 2$ & 7 & R2 \\
\hline Vapor barrier, 0.06in & $5,276 \mathrm{~m} 2$ & 42.16 & R1 \\
\hline $\begin{array}{l}\text { Medium density fiberboard (MDF), } \\
0.75 \text { in (Canadian Wood Counc... }\end{array}$ & $80.69 \mathrm{~m} 2$ & 5.37 & R2 \\
\hline
\end{tabular}

\section{Windows and doors}

\begin{tabular}{|l|l|l|l|}
$\begin{array}{l}\text { Aluminum window, fixed and } \\
\text { ribbon, } 1.2 \mathrm{~m} \times 1.5 \mathrm{~m}, 24.8 \\
\text { kg/piec... }\end{array}$ & $18.06 \mathrm{~m} 2$ & 1.25 & \\
\hline $\begin{array}{l}\text { Steel door, interior, } 13 / 4 \mathrm{in} \times 4 \times 8 \mathrm{ft} \\
\text { (Total Door Systems) }\end{array}$ & $55.1 \mathrm{~m} 2$ & 282.83 & \\
\hline $\begin{array}{l}\text { Door, exterior, Honeycomb core, } 1 \\
\text { 3/4in, } 14-18 \text { gauge, 48.42x.. }\end{array}$ & $66.74 \mathrm{~m} 2$ & 115.81 & \\
\begin{tabular}{|l|l|l|} 
Traditional curtain wall, $1.5 \mathrm{~m} \mathrm{x}$ \\
$1.6 \mathrm{~m}, 35.6 \mathrm{~kg} /$ piece, $16001 \ldots$
\end{tabular} & $523.9 \mathrm{~m} 2$ & 36.36 & \\
\hline
\end{tabular}


One-Click LCA Results - Replacement and Refurbishment Phase

\begin{tabular}{|c|c|c|c|}
\hline Resource & User input & $\begin{array}{l}\text { Global warming } \\
\text { kg CO2e }\end{array}$ & Comments \\
\hline \multicolumn{4}{|l|}{ External Wall } \\
\hline $\begin{array}{l}\text { Concrete masonry unit } \\
(\mathrm{CMU}), 7 \text { 7/8inx7 5/8inx15 } \\
\text { 5/8in, HW Re... }\end{array}$ & $8.8 \mathrm{~m} 3$ & & W3 \\
\hline $\begin{array}{l}\text { Steel framing systems, } \\
\text { Studrite, Joistrite, Framerite, } \\
\text { Viper... }\end{array}$ & 90.18 kg & & W4 \\
\hline $\begin{array}{l}\text { Steel framing systems, } \\
\text { Studrite, Joistrite, Framerite, } \\
\text { Viper... }\end{array}$ & $456.3 \mathrm{~kg}$ & & W3 \\
\hline $\begin{array}{l}\text { Insulated metal panel, } 1 \\
\text { 3/4in-4inx36inx6-48ft, } \\
\text { Versapanel (... }\end{array}$ & $10.45 \mathrm{~m} 3$ & & W2 \\
\hline $\begin{array}{l}\text { Mineral wool insulation batt, } \\
\text { R11, EcoBatt Insulation with } \\
\text { E... }\end{array}$ & $19.27 \mathrm{~m} 2$ & 1.88 & W4 \\
\hline $\begin{array}{l}\text { Mineral wool insulation batt, } \\
\text { R11, EcoBatt Insulation with } \\
\text { E... }\end{array}$ & $97.79 \mathrm{~m} 2$ & 9.53 & W3 \\
\hline $\begin{array}{l}\text { XPS insulation (extruded } \\
\text { polystyrene), 1.02in }\end{array}$ & $19.27 \mathrm{~m} 2$ & 622.25 & W4 \\
\hline $\begin{array}{l}\text { XPS insulation (extruded } \\
\text { polystyrene), 1.02in }\end{array}$ & $97.79 \mathrm{~m} 2$ & $3,157.56$ & W3 \\
\hline $\begin{array}{l}\text { Roll formed steel panels, } 24 \\
\text { gauge, } 5.9 \mathrm{~kg} / \mathrm{m} 2 \text { (CSSBI) }\end{array}$ & $19.27 \mathrm{~m} 2$ & & W4 \\
\hline $\begin{array}{l}\text { Gypsum Board Type X, 5/8", } \\
2.25 \text { psf (CertainTeed } \\
\text { Toronto Fac... }\end{array}$ & $19.27 \mathrm{~m} 2$ & & W4 \\
\hline $\begin{array}{l}\text { Gypsum Board Type X, 5/8", } \\
2.25 \text { psf (CertainTeed } \\
\text { Toronto Fac... }\end{array}$ & $97.79 \mathrm{~m} 2$ & & W3 \\
\hline Vapor barrier, 0.06in & $19.27 \mathrm{~m} 2$ & 14.39 & W4 \\
\hline Vapor barrier, 0.06in & $97.79 \mathrm{~m} 2$ & 73.01 & W3 \\
\hline
\end{tabular}




\begin{tabular}{|l|l|l|l|}
$\begin{array}{l}\text { Medium density fiberboard } \\
\text { (MDF), 0.75in (Canadian } \\
\text { Wood Counc... }\end{array}$ & $19.27 \mathrm{~m} 2$ & W4 \\
\hline $\begin{array}{l}\text { Medium density fiberboard } \\
\text { (MDF), 0.75in (Canadian } \\
\text { Wood Counc... }\end{array}$ & $97.79 \mathrm{~m} 2$ & W3 \\
\hline
\end{tabular}

\section{Partition}

\begin{tabular}{|c|c|c|c|}
\hline Concrete masonry unit & $12.48 \mathrm{~m} 3$ & & P2 \\
\hline Concrete masonry unit & $12.92 \mathrm{~m} 3$ & & P3 \\
\hline Concrete masonry unit & $13.36 \mathrm{~m} 3$ & & P1 \\
\hline Concrete masonry unit & $14.91 \mathrm{~m} 3$ & & P5 \\
\hline Concrete masonry unit & $23.99 \mathrm{~m} 3$ & & |P4 \\
\hline $\begin{array}{l}\text { Bio-based tile flooring, } \\
12 \times 12,12 \times 24 \mathrm{in}, 0.125 \mathrm{in}, \\
1.44 \mathrm{lbs} / \ldots\end{array}$ & $95.4 \mathrm{~m} 2$ & $1,313.63$ & P1 \\
\hline $\begin{array}{l}\text { Bio-based tile flooring, } \\
12 \times 12,12 \times 24 \mathrm{in}, 0.125 \mathrm{in}, \\
1.44 \mathrm{lbs} / \ldots\end{array}$ & $171.35 \mathrm{~m} 2$ & $2,359.48$ & P4 \\
\hline $\begin{array}{l}\text { Bio-based tile flooring, } \\
12 \times 12,12 \times 24 \mathrm{in}, 0.125 \mathrm{in}, \\
1.44 \mathrm{lbs} / \ldots\end{array}$ & $298.2 \mathrm{~m} 2$ & $4,106.21$ & P5 \\
\hline $\begin{array}{l}\text { Steel framing systems, } \\
\text { Studrite, Joistrite, Framerite, } \\
\text { Viper... }\end{array}$ & $9.56 \mathrm{~kg}$ & & $\begin{array}{l}\text { P2 resilient } \\
\text { channel }\end{array}$ \\
\hline $\begin{array}{l}\text { Steel framing systems, } \\
\text { Studrite, Joistrite, Framerite, } \\
\text { Viper... }\end{array}$ & $9.68 \mathrm{~kg}$ & & $\begin{array}{l}\text { P1 resilient } \\
\text { channel }\end{array}$ \\
\hline $\begin{array}{l}\text { Steel framing systems, } \\
\text { Studrite, Joistrite, Framerite, } \\
\text { Viper... }\end{array}$ & $14.22 \mathrm{~kg}$ & & $\begin{array}{l}\text { P3 resilient } \\
\text { channel }\end{array}$ \\
\hline $\begin{array}{l}\text { Steel framing systems, } \\
\text { Studrite, Joistrite, Framerite, } \\
\text { Viper... }\end{array}$ & $17.89 \mathrm{~kg}$ & & $\begin{array}{l}\text { P3 Furring } \\
\text { channel }\end{array}$ \\
\hline $\begin{array}{l}\text { Pressed glass partition, } \\
0.236 \text { in, } 152.3 \text { lbs/ft3, } \\
\text { InfinteGlas... }\end{array}$ & $171.35 \mathrm{~m} 2$ & 6.56 & P4 \\
\hline
\end{tabular}




\begin{tabular}{|l|l|l|l|}
\hline $\begin{array}{l}\text { Mineral wool insulation batt, } \\
\text { R11, EcoBatt Insulation with } \\
\text { E... }\end{array}$ & $89.12 \mathrm{~m} 2$ & P.72 \\
\hline $\begin{array}{l}\text { Mineral wool insulation batt, } \\
\text { R11, EcoBatt Insulation with } \\
\text { E.. }\end{array}$ & $95.4 \mathrm{~m} 2$ & 3.98 & $\mathrm{P} 1$ \\
\hline $\begin{array}{l}\text { Mineral wool insulation batt, } \\
\text { R11, EcoBatt Insulation with } \\
\text { E... }\end{array}$ & $171.35 \mathrm{~m} 2$ & 7.16 & $\mathrm{P} 4$ \\
\hline $\begin{array}{l}\text { Rebar, hot-rolled, Knoxville } \\
\text { mill, 490 Ibs/ft3 (Gerdau) }\end{array}$ & $55.46 \mathrm{~kg}$ & & $\mathrm{P} 3$ \\
\hline $\begin{array}{l}\text { Rebar, hot-rolled, Knoxville } \\
\text { mill, 490 Ibs/ft3 (Gerdau) }\end{array}$ & $72.66 \mathrm{~kg}$ & & $\mathrm{P} 2$ \\
\hline $\begin{array}{l}\text { Rebar, hot-rolled, Knoxville } \\
\text { mill, 490 Ibs/ft3 (Gerdau) }\end{array}$ & $77.78 \mathrm{~kg}$ & $\mathrm{P} 1$ \\
\hline $\begin{array}{l}\text { Rebar, hot-rolled, Knoxville } \\
\text { mill, 490 Ibs/ft3 (Gerdau) }\end{array}$ & $121.6 \mathrm{~kg}$ & $\mathrm{P} 5$ \\
\hline $\begin{array}{l}\text { Rebar, hot-rolled, Knoxville } \\
\text { mill, 490 Ibs/ft3 (Gerdau) }\end{array}$ & $139.7 \mathrm{~kg}$ & & $\mathrm{P} 4$ \\
\hline $\begin{array}{l}\text { Medium density fiberboard } \\
\text { (MDF), 0.75in (Canadian } \\
\text { Wood Counc... }\end{array}$ & $89.12 \mathrm{~m} 2$ & & \\
\hline $\begin{array}{l}\text { Medium density fiberboard } \\
\text { (MDF), 0.75in (Canadian } \\
\text { Wood Counc... }\end{array}$ & $95.4 \mathrm{~m} 2$ & & \\
\hline $\begin{array}{l}\text { Medium density fiberboard } \\
\text { (MDF), 0.75in (Canadian } \\
\text { Wood Counc... }\end{array}$ & $171.35 \mathrm{~m} 2$ & & \\
\hline $\begin{array}{l}\text { Medium density fiberboard } \\
\text { (MDF), O.75in (Canadian } \\
\text { Wood Counc... }\end{array}$ & $171.35 \mathrm{~m} 2$ & & \\
\hline
\end{tabular}

Floors and roof 


\begin{tabular}{|c|c|c|c|}
\hline $\begin{array}{l}\text { Fluid-applied rubber asphalt } \\
\text { roofing, } 0.17 \text { in }\end{array}$ & $80.69 \mathrm{~m} 2$ & $1,104.48$ & R2 \\
\hline $\begin{array}{l}\text { Ready-mix concrete, } 25 \mathrm{MPa} \\
\text { GU cem. cem. with air entr. } \\
0-14 \% \ldots\end{array}$ & $7.6 \mathrm{~m} 3$ & & F6 \\
\hline $\begin{array}{l}\text { Ready-mix concrete, } 25 \mathrm{MPa} \\
\text { GU cem. cem. with air entr. } \\
0-14 \% \ldots\end{array}$ & $9.32 \mathrm{~m} 3$ & & C3 \\
\hline $\begin{array}{l}\text { Ready-mix concrete, } 25 \mathrm{MPa} \\
\mathrm{GU} \text { cem. cem. with air entr. } \\
0-14 \% \ldots\end{array}$ & $11.25 \mathrm{~m} 3$ & & F8 \\
\hline $\begin{array}{l}\text { Ready-mix concrete, } 25 \mathrm{MPa} \\
\text { GU cem. cem. with air entr. } \\
0-14 \% \ldots\end{array}$ & $15.6 \mathrm{~m} 3$ & & F2 \\
\hline $\begin{array}{l}\text { Ready-mix concrete, } 25 \mathrm{MPa} \\
\text { GU cem. cem. with air entr. } \\
0-14 \% \ldots\end{array}$ & $78 \mathrm{~m} 3$ & & $F 2$ \\
\hline $\begin{array}{l}\text { Ready-mix concrete, } 25 \mathrm{MPa} \\
\text { GU cem. cem. with air entr. } \\
0-14 \% \ldots\end{array}$ & 180.53 m3 & & $\mathrm{F} 1$ \\
\hline $\begin{array}{l}\text { Ready-mix concrete, } 25 \mathrm{MPa} \\
\text { GU cem. cem. with air entr. } \\
0-14 \% \ldots\end{array}$ & 305.69 m3 & & $\mathrm{F} 1$ \\
\hline $\begin{array}{l}\text { Ready-mix concrete, } 25 \mathrm{MPa} \\
\text { GU cem. cem. with air entr. } \\
0-14 \% \ldots\end{array}$ & $601.75 \mathrm{~m} 3$ & & $\mathrm{~F} 1$ \\
\hline $\begin{array}{l}\text { Steel framing systems, } \\
\text { Studrite, Joistrite, Framerite, } \\
\text { Viper... }\end{array}$ & $14.45 \mathrm{~kg}$ & & $\begin{array}{l}\text { C2 resilient } \\
\text { channels }\end{array}$ \\
\hline $\begin{array}{l}\text { Steel framing systems, } \\
\text { Studrite, Joistrite, Framerite, } \\
\text { Viper... }\end{array}$ & 176 kg & & C2 \\
\hline $\begin{array}{l}\text { Gypsum board, wallboard, } \\
\text { regular, } 0.5 \text { inch }(12.7 \mathrm{~mm})\end{array}$ & 129.84 m2 & 326.24 & C2 \\
\hline $\begin{array}{l}\text { Mineral wool insulation batt, } \\
\text { R11, EcoBatt Insulation with } \\
\text { E... }\end{array}$ & $129.84 \mathrm{~m} 2$ & 12.65 & C2 \\
\hline $\begin{array}{l}\text { ISO foam insulation, } 0.5-2 \mathrm{in}, \\
\text { Tuff-R Insulation (Dow) }\end{array}$ & $5,276 \mathrm{~m} 2$ & $72,610.09$ & R1 \\
\hline
\end{tabular}




\begin{tabular}{|c|c|c|c|}
\hline $\begin{array}{l}\text { Spray foam insulation, } \\
1.02 \text { in }\end{array}$ & $80.69 \mathrm{~m} 2$ & 7,787.05 & R2 \\
\hline $\begin{array}{l}\text { Composite metal decking, } \\
30 \text { mil }\end{array}$ & $80.69 \mathrm{~m} 2$ & $1,254.91$ & R2 \\
\hline $\begin{array}{l}\text { Rebar, hot-rolled, Knoxville } \\
\text { mill, } 490 \text { lbs/ft3 (Gerdau) }\end{array}$ & $54.24 \mathrm{~kg}$ & & C3 \\
\hline $\begin{array}{l}\text { Rebar, hot-rolled, Knoxville } \\
\text { mill, } 490 \text { lbs/ft3 (Gerdau) }\end{array}$ & 982.7 kg & & F8 \\
\hline $\begin{array}{l}\text { Steel roof and floor deck, 22- } \\
16 \text { gauge (Steel Deck } \\
\text { Institute... }\end{array}$ & $320 \mathrm{~kg}$ & & C3 \\
\hline $\begin{array}{l}\text { Steel roof and floor deck, 22- } \\
16 \text { gauge (Steel Deck } \\
\text { Institute... }\end{array}$ & $443.2 \mathrm{~kg}$ & & F6 \\
\hline $\begin{array}{l}\text { Steel roof and floor deck, 22- } \\
16 \text { gauge (Steel Deck } \\
\text { Institute... }\end{array}$ & $668 \mathrm{~kg}$ & & C2 \\
\hline $\begin{array}{l}\text { Steel roof and floor deck, 22- } \\
16 \text { gauge (Steel Deck } \\
\text { Institute... }\end{array}$ & $63,314 \mathrm{~kg}$ & & R1 \\
\hline $\begin{array}{l}\text { Gypsum Board Type X, 5/8", } \\
\text { 2.25 psf (CertainTeed } \\
\text { Toronto Fac... }\end{array}$ & $80.69 \mathrm{~m} 2$ & & R2 \\
\hline Vapor barrier, 0.06in & $5,276 \mathrm{~m} 2$ & $3,938.88$ & R1 \\
\hline $\begin{array}{l}\text { Medium density fiberboard } \\
\text { (MDF), 0.75in (Canadian } \\
\text { Wood Counc... }\end{array}$ & 80.69 m2 & & R2 \\
\hline
\end{tabular}

\section{Windows and doors}

\begin{tabular}{|l|l|l|l|}
\hline $\begin{array}{l}\text { Aluminum window, fixed and } \\
\text { ribbon, } 1.2 \mathrm{~m} \times 1.5 \mathrm{~m}, 24.8 \\
\mathrm{~kg} / \mathrm{piec} . .\end{array}$ & $18.06 \mathrm{~m} 2$ & $30,920.43$ & \\
\hline $\begin{array}{l}\text { Steel door, interior, } 13 / 4 \mathrm{in} \times \\
4 \times 8 \mathrm{ft} \text { (Total Door Systems) }\end{array}$ & $55.1 \mathrm{~m} 2$ & $20,528.82$ &
\end{tabular}




\begin{tabular}{|l|l|l|l|}
$\begin{array}{l}\text { Door, exterior, Honeycomb } \\
\text { core, } 13 / 4 \text { in, } 14-18 \text { gauge, } \\
48.42 x \ldots\end{array}$ & $66.74 \mathrm{~m} 2$ & $8,442.47$ & \\
\hline $\begin{array}{l}\text { Traditional curtain wall, } 1.5 \mathrm{~m} \\
\mathrm{x} 1.6 \mathrm{~m}, 35.6 \mathrm{~kg} / \text { piece, } 1600 \\
1 \ldots\end{array}$ & $523.9 \mathrm{~m} 2$ & & \\
\hline
\end{tabular}


One-Click LCA Results - Deconstruction and Waste Phase

\begin{tabular}{|c|c|c|c|}
\hline Resource & User input & $\begin{array}{l}\text { Global warming } \\
\mathrm{kg} \mathrm{CO} 2 \mathrm{e}\end{array}$ & Comments \\
\hline \multicolumn{4}{|l|}{ External Wall } \\
\hline $\begin{array}{l}\text { Concrete masonry unit } \\
\text { (CMU), } 7 \text { 7/8inx7 5/8inx15 } \\
\text { 5/8in, HW Re... }\end{array}$ & $8.8 \mathrm{~m} 3$ & 195.07 & W3 \\
\hline $\begin{array}{l}\text { Steel framing systems, } \\
\text { Studrite, Joistrite, } \\
\text { Framerite, Viper... }\end{array}$ & $90.18 \mathrm{~kg}$ & 0.7 & W4 \\
\hline $\begin{array}{l}\text { Steel framing systems, } \\
\text { Studrite, Joistrite, } \\
\text { Framerite, Viper... }\end{array}$ & $456.3 \mathrm{~kg}$ & 3.54 & W3 \\
\hline $\begin{array}{l}\text { Insulated metal panel, } 1 \\
\text { 3/4in-4inx36inx6-48ft, } \\
\text { Versapanel (... }\end{array}$ & $10.45 \mathrm{~m} 3$ & 17.39 & W2 \\
\hline $\begin{array}{l}\text { Mineral wool insulation } \\
\text { batt, R11, EcoBatt } \\
\text { Insulation with E... }\end{array}$ & $19.27 \mathrm{~m} 2$ & 2.55 & W4 \\
\hline $\begin{array}{l}\text { Mineral wool insulation } \\
\text { batt, R11, EcoBatt } \\
\text { Insulation with E... }\end{array}$ & $97.79 \mathrm{~m} 2$ & 12.94 & W3 \\
\hline $\begin{array}{l}\text { XPS insulation (extruded } \\
\text { polystyrene), 1.02in }\end{array}$ & $19.27 \mathrm{~m} 2$ & 1.17 & W4 \\
\hline $\begin{array}{l}\text { XPS insulation (extruded } \\
\text { polystyrene), 1.02in }\end{array}$ & $97.79 \mathrm{~m} 2$ & 5.92 & W3 \\
\hline $\begin{array}{l}\text { Roll formed steel panels, } \\
24 \text { gauge, } 5.9 \mathrm{~kg} / \mathrm{m} 2 \\
\text { (CSSBI) }\end{array}$ & $19.27 \mathrm{~m} 2$ & 0.3 & W4 \\
\hline $\begin{array}{l}\text { Gypsum Board Type X, } \\
5 / 8 ", 2.25 \text { psf } \\
\text { (CertainTeed Toronto } \\
\text { Fac... }\end{array}$ & $19.27 \mathrm{~m} 2$ & 9.98 & W4 \\
\hline $\begin{array}{l}\text { Gypsum Board Type X, } \\
5 / 8 ", 2.25 \text { psf } \\
\text { (CertainTeed Toronto } \\
\text { Fac... }\end{array}$ & $97.79 \mathrm{~m} 2$ & 50.62 & W3 \\
\hline
\end{tabular}




\begin{tabular}{|l|l|l|l|} 
Vapor barrier, 0.06in & $19.27 \mathrm{~m} 2$ & 0 & W4 \\
\hline Vapor barrier, 0.06in & $97.79 \mathrm{~m} 2$ & 0 & W3 \\
\hline $\begin{array}{l}\text { Medium density fiberboard } \\
\text { (MDF), 0.75in (Canadian } \\
\text { Wood Counc... }\end{array}$ & $19.27 \mathrm{~m} 2$ & 1.49 & W4 \\
\hline $\begin{array}{l}\text { Medium density fiberboard } \\
\text { (MDF), 0.75in (Canadian } \\
\text { Wood Counc... }\end{array}$ & $97.79 \mathrm{~m} 2$ & 7.56 & W3 \\
\hline
\end{tabular}

\section{Partiton wall}

\begin{tabular}{|c|c|c|c|}
\hline Concrete masonry unit & $12.48 \mathrm{~m} 3$ & 0 & P2 \\
\hline Concrete masonry unit & $12.92 \mathrm{~m} 3$ & 0 & P3 \\
\hline Concrete masonry unit & 13.36 m3 & 0 & |P1 \\
\hline Concrete masonry unit & $14.91 \mathrm{~m} 3$ & 0 & |P5 \\
\hline Concrete masonry unit & 23.99 m3 & 0 & |P4 \\
\hline $\begin{array}{l}\text { Bio-based tile flooring, } \\
12 \times 12,12 \times 24 \mathrm{in}, 0.125 \mathrm{in} \text {, } \\
1.44 \mathrm{lbs} / \ldots\end{array}$ & $95.4 \mathrm{~m} 2$ & 31.19 & P1 \\
\hline $\begin{array}{l}\text { Bio-based tile flooring, } \\
12 \times 12,12 \times 24 \mathrm{in}, 0.125 \mathrm{in}, \\
1.44 \mathrm{lbs} / \ldots\end{array}$ & 171.35 m2 & 56.03 & P4 \\
\hline $\begin{array}{l}\text { Bio-based tile flooring, } \\
12 \times 12,12 \times 24 \text { in, } 0.125 \mathrm{in} \text {, } \\
1.44 \mathrm{lbs} / \ldots\end{array}$ & $298.2 \mathrm{~m} 2$ & 97.5 & P5 \\
\hline $\begin{array}{l}\text { Steel framing systems, } \\
\text { Studrite, Joistrite, } \\
\text { Framerite, Viper... }\end{array}$ & $9.56 \mathrm{~kg}$ & 0.07 & P2 resilient channel \\
\hline $\begin{array}{l}\text { Steel framing systems, } \\
\text { Studrite, Joistrite, } \\
\text { Framerite, Viper... }\end{array}$ & $9.68 \mathrm{~kg}$ & 0.08 & P1 resilient channel \\
\hline $\begin{array}{l}\text { Steel framing systems, } \\
\text { Studrite, Joistrite, } \\
\text { Framerite, Viper... }\end{array}$ & $14.22 \mathrm{~kg}$ & 0.11 & P3 resilient channel \\
\hline $\begin{array}{l}\text { Steel framing systems, } \\
\text { Studrite, Joistrite, } \\
\text { Framerite, Viper... }\end{array}$ & $17.89 \mathrm{~kg}$ & 0.14 & P3 Furring channel \\
\hline
\end{tabular}




\begin{tabular}{|c|c|c|c|}
\hline \begin{tabular}{|l} 
Pressed glass partition, \\
$0.236 i n, 152.3$ lbs/ft3, \\
InfinteGlas...
\end{tabular} & $171.35 \mathrm{~m} 2$ & 71.97 & P4 \\
\hline $\begin{array}{l}\text { Mineral wool insulation } \\
\text { batt, R11, EcoBatt } \\
\text { Insulation with E... }\end{array}$ & $89.12 \mathrm{~m} 2$ & 5.05 & P2 \\
\hline $\begin{array}{l}\text { Mineral wool insulation } \\
\text { batt, R11, EcoBatt } \\
\text { Insulation with E... }\end{array}$ & $95.4 \mathrm{~m} 2$ & 5.41 & P1 \\
\hline $\begin{array}{l}\text { Mineral wool insulation } \\
\text { batt, R11, EcoBatt } \\
\text { Insulation with E... }\end{array}$ & $171.35 \mathrm{~m} 2$ & 9.72 & P4 \\
\hline $\begin{array}{l}\text { Rebar, hot-rolled, } \\
\text { Knoxville mill, } 490 \text { Ibs/ft3 } \\
\text { (Gerdau) }\end{array}$ & $55.46 \mathrm{~kg}$ & 0.43 & P3 \\
\hline $\begin{array}{l}\text { Rebar, hot-rolled, } \\
\text { Knoxville mill, } 490 \text { Ibs/ft3 } \\
\text { (Gerdau) }\end{array}$ & $72.66 \mathrm{~kg}$ & 0.56 & P2 \\
\hline $\begin{array}{l}\text { Rebar, hot-rolled, } \\
\text { Knoxville mill, } 490 \text { Ibs/ft3 } \\
\text { (Gerdau) }\end{array}$ & $77.78 \mathrm{~kg}$ & 0.6 & P1 \\
\hline $\begin{array}{l}\text { Rebar, hot-rolled, } \\
\text { Knoxville mill, } 490 \text { Ibs/ft3 } \\
\text { (Gerdau) }\end{array}$ & $121.6 \mathrm{~kg}$ & 0.94 & P5 \\
\hline $\begin{array}{l}\text { Rebar, hot-rolled, } \\
\text { Knoxville mill, } 490 \text { lbs/ft3 } \\
\text { (Gerdau) }\end{array}$ & $139.7 \mathrm{~kg}$ & 1.08 & P4 \\
\hline $\begin{array}{l}\text { Medium density fiberboard } \\
\text { (MDF), } 0.75 \text { in (Canadian } \\
\text { Wood Counc... }\end{array}$ & $89.12 \mathrm{~m} 2$ & 6.89 & P2 \\
\hline $\begin{array}{l}\text { Medium density fiberboard } \\
\text { (MDF), } 0.75 \text { in (Canadian } \\
\text { Wood Counc... }\end{array}$ & $95.4 \mathrm{~m} 2$ & 7.37 & P1 \\
\hline $\begin{array}{l}\text { Medium density fiberboard } \\
\text { (MDF), } 0.75 \text { in (Canadian } \\
\text { Wood Counc... }\end{array}$ & $171.35 \mathrm{~m} 2$ & 13.24 & P4 \\
\hline
\end{tabular}


Medium density fiberboard

(MDF), 0.75in (Canadian

Wood Counc...

\section{Floors and roof}

\begin{tabular}{|c|c|c|c|}
\hline $\begin{array}{l}\text { Fluid-applied rubber } \\
\text { asphalt roofing, } 0.17 \mathrm{in}\end{array}$ & $80.69 \mathrm{~m} 2$ & 20.61 & R2 \\
\hline $\begin{array}{l}\text { Ready-mix concrete, } \\
25 \mathrm{MPa} \text { GU cem. cem. with } \\
\text { air entr. } 0-14 \% \text {... }\end{array}$ & $7.6 \mathrm{~m} 3$ & 201.89 & F6 \\
\hline $\begin{array}{l}\text { Ready-mix concrete, } \\
25 \mathrm{MPa} \text { GU cem. cem. with } \\
\text { air entr. } 0-14 \% \text {... }\end{array}$ & $9.32 \mathrm{~m} 3$ & 247.71 & C3 \\
\hline $\begin{array}{l}\text { Ready-mix concrete, } \\
25 \mathrm{MPa} \text { GU cem. cem. with } \\
\text { air entr. } 0-14 \% \text {... }\end{array}$ & $11.25 \mathrm{~m} 3$ & 298.84 & F8 \\
\hline $\begin{array}{l}\text { Ready-mix concrete, } \\
25 \mathrm{MPa} \text { GU cem. cem. with } \\
\text { air entr. } 0-14 \% \text {... }\end{array}$ & $15.6 \mathrm{~m} 3$ & 414.4 & F2 \\
\hline $\begin{array}{l}\text { Ready-mix concrete, } \\
25 \mathrm{MPa} \text { GU cem. cem. with } \\
\text { air entr. } 0-14 \% \text {... }\end{array}$ & $78 \mathrm{~m} 3$ & $2,071.99$ & $\mathrm{~F} 2$ \\
\hline $\begin{array}{l}\text { Ready-mix concrete, } \\
25 \mathrm{MPa} \text { GU cem. cem. with } \\
\text { air entr. } 0-14 \% \text {... }\end{array}$ & $180.53 \mathrm{~m} 3$ & $4,795.59$ & F1 \\
\hline $\begin{array}{l}\text { Ready-mix concrete, } \\
25 \mathrm{MPa} \text { GU cem. cem. with } \\
\text { air entr. } 0-14 \% \text {... }\end{array}$ & $305.69 \mathrm{~m} 3$ & $8,120.34$ & $\mathrm{~F} 1$ \\
\hline $\begin{array}{l}\text { Ready-mix concrete, } \\
25 \mathrm{MPa} \text { GU cem. cem. with } \\
\text { air entr. } 0-14 \% \text {... }\end{array}$ & $601.75 \mathrm{~m} 3$ & $15,984.87$ & $\mathrm{~F} 1$ \\
\hline $\begin{array}{l}\text { Steel framing systems, } \\
\text { Studrite, Joistrite, } \\
\text { Framerite, Viper... }\end{array}$ & $14.45 \mathrm{~kg}$ & 0.11 & C2 resilient channels \\
\hline $\begin{array}{l}\text { Steel framing systems, } \\
\text { Studrite, Joistrite, } \\
\text { Framerite, Viper... }\end{array}$ & $176 \mathrm{~kg}$ & 1.36 & C2 \\
\hline $\begin{array}{l}\text { Gypsum board, wallboard, } \\
\text { regular, } 0.5 \text { inch (12.7 } \\
\mathrm{mm} \text { ) }\end{array}$ & $129.84 \mathrm{~m} 2$ & 46.14 & C2 \\
\hline
\end{tabular}




\begin{tabular}{|c|c|c|c|}
\hline $\begin{array}{l}\text { Mineral wool insulation } \\
\text { batt, R11, EcoBatt } \\
\text { Insulation with E... }\end{array}$ & $129.84 \mathrm{~m} 2$ & 17.18 & $\mathrm{C} 2$ \\
\hline $\begin{array}{l}\text { ISO foam insulation, 0.5- } \\
\text { 2in, Tuff-R Insulation } \\
\text { (Dow) }\end{array}$ & $5,276 \mathrm{~m} 2$ & 598.35 & R1 \\
\hline $\begin{array}{l}\text { Spray foam insulation, } \\
\text { 1.02in }\end{array}$ & $80.69 \mathrm{~m} 2$ & 117.59 & R2 \\
\hline $\begin{array}{l}\text { Composite metal decking, } \\
30 \text { mil }\end{array}$ & $80.69 \mathrm{~m} 2$ & 0 & R2 \\
\hline $\begin{array}{l}\text { Rebar, hot-rolled, } \\
\text { Knoxville mill, } 490 \text { lbs/ft3 } \\
\text { (Gerdau) }\end{array}$ & $54.24 \mathrm{~kg}$ & 0.42 & C3 \\
\hline $\begin{array}{l}\text { Rebar, hot-rolled, } \\
\text { Knoxville mill, } 490 \text { lbs/ft3 } \\
\text { (Gerdau) }\end{array}$ & $982.7 \mathrm{~kg}$ & 7.62 & F8 \\
\hline $\begin{array}{l}\text { Steel roof and floor deck, } \\
22-16 \text { gauge (Steel Deck } \\
\text { Institute... }\end{array}$ & $320 \mathrm{~kg}$ & 2.48 & C3 \\
\hline $\begin{array}{l}\text { Steel roof and floor deck, } \\
22-16 \text { gauge (Steel Deck } \\
\text { Institute... }\end{array}$ & $443.2 \mathrm{~kg}$ & 3.43 & F6 \\
\hline $\begin{array}{l}\text { Steel roof and floor deck, } \\
22-16 \text { gauge (Steel Deck } \\
\text { Institute... }\end{array}$ & $668 \mathrm{~kg}$ & 5.18 & C2 \\
\hline $\begin{array}{l}\text { Steel roof and floor deck, } \\
22-16 \text { gauge (Steel Deck } \\
\text { Institute... }\end{array}$ & $63,314 \mathrm{~kg}$ & 490.68 & R1 \\
\hline $\begin{array}{l}\text { Gypsum Board Type X, } \\
5 / 8 ", 2.25 \text { psf } \\
\text { (CertainTeed Toronto } \\
\text { Fac... }\end{array}$ & $80.69 \mathrm{~m} 2$ & 41.77 & R2 \\
\hline Vapor barrier, 0.06in & $5,276 \mathrm{~m} 2$ & | 0 & R1 \\
\hline $\begin{array}{l}\text { Medium density fiberboard } \\
\text { (MDF), 0.75in (Canadian } \\
\text { Wood Counc... }\end{array}$ & $80.69 \mathrm{~m} 2$ & 6.23 & R2 \\
\hline
\end{tabular}

\section{Windows and doors}




\begin{tabular}{|l|l|l|l|}
$\begin{array}{l}\text { Aluminum window, fixed } \\
\text { and ribbon, } 1.2 \mathrm{~m} \times 1.5 \mathrm{~m}, \\
24.8 \mathrm{~kg} / \text { piec... }\end{array}$ & $18.06 \mathrm{~m} 2$ & 0.28 & \\
\begin{tabular}{|l|l|} 
Steel door, interior, $13 / 4 \mathrm{in}$ \\
$\mathrm{x} 4 \times 8 \mathrm{ft}($ Total Door \\
Systems)
\end{tabular} & $55.1 \mathrm{~m} 2$ & 63.16 & \\
\hline $\begin{array}{l}\text { Door, exterior, Honeycomb } \\
\text { core, } 13 / 4 \mathrm{in}, 14-18 \\
\text { gauge, } 48.42 \mathrm{x} \ldots\end{array}$ & $66.74 \mathrm{~m} 2$ & 25.86 & \\
\begin{tabular}{|l|l|} 
Traditional curtain wall, \\
$1.5 \mathrm{~m} \times 1.6 \mathrm{~m}, 35.6$ \\
$\mathrm{~kg} /$ piece, $16001 \ldots$
\end{tabular} & $523.9 \mathrm{~m} 2$ & 8.12 & \\
\hline
\end{tabular}




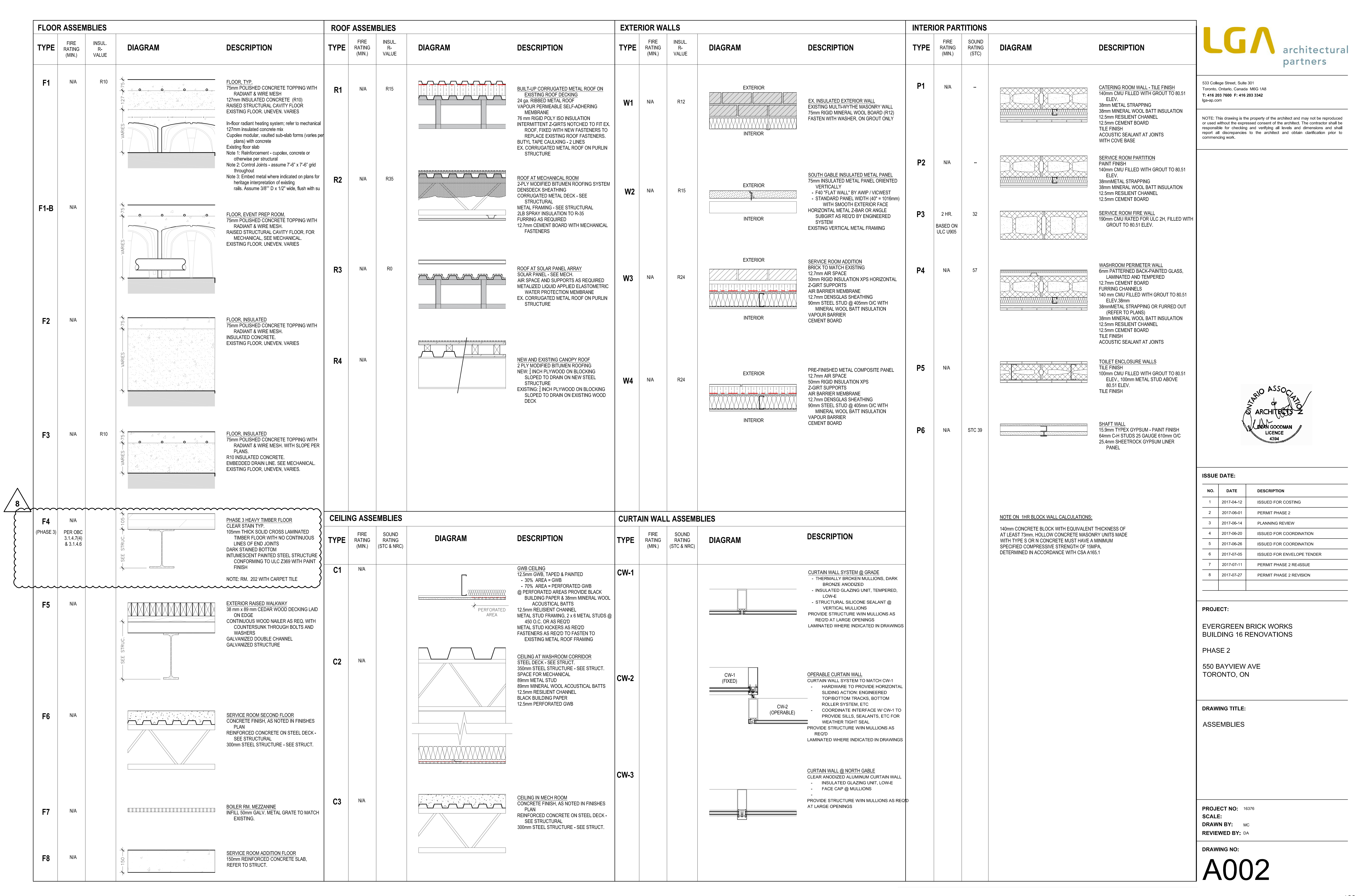




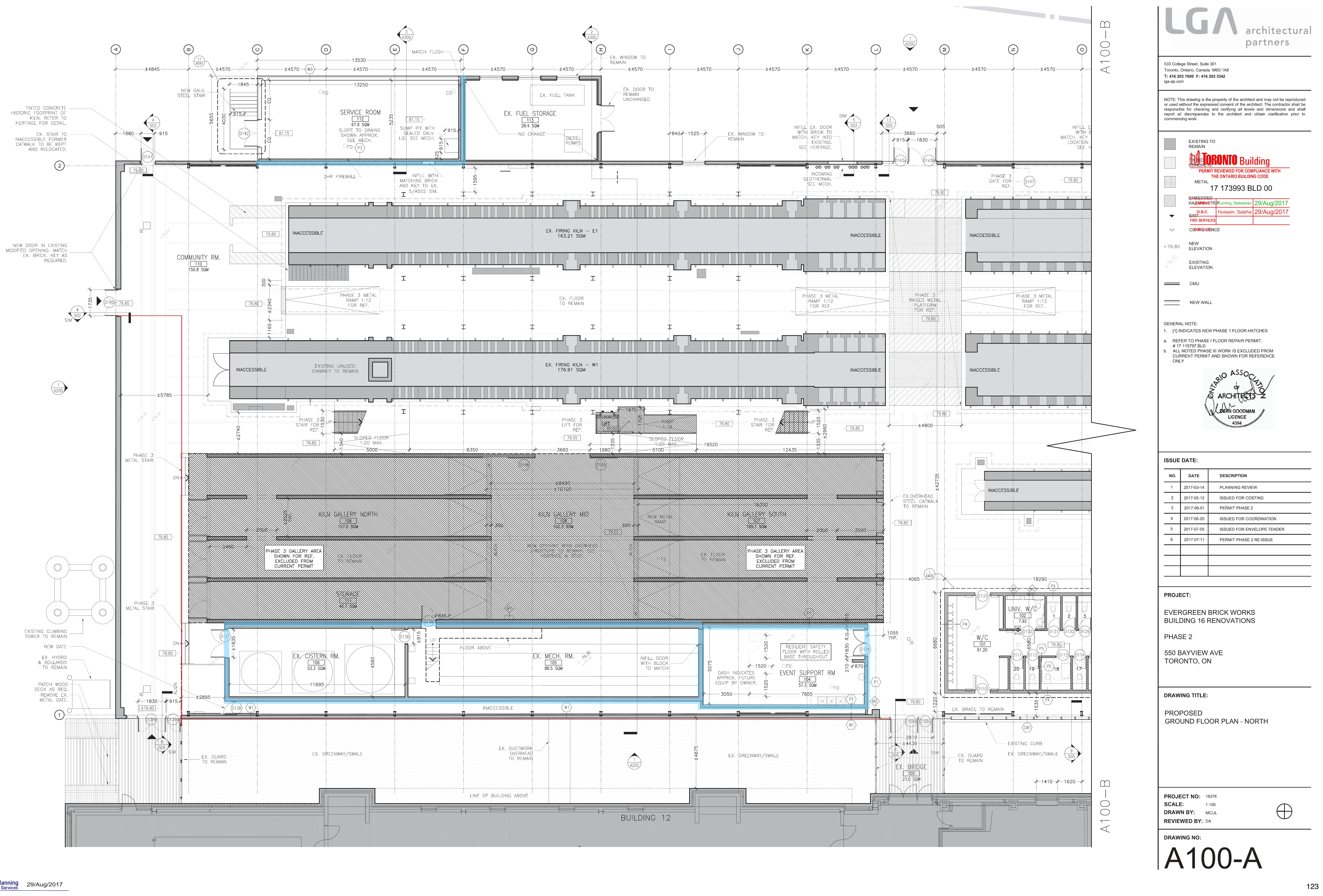




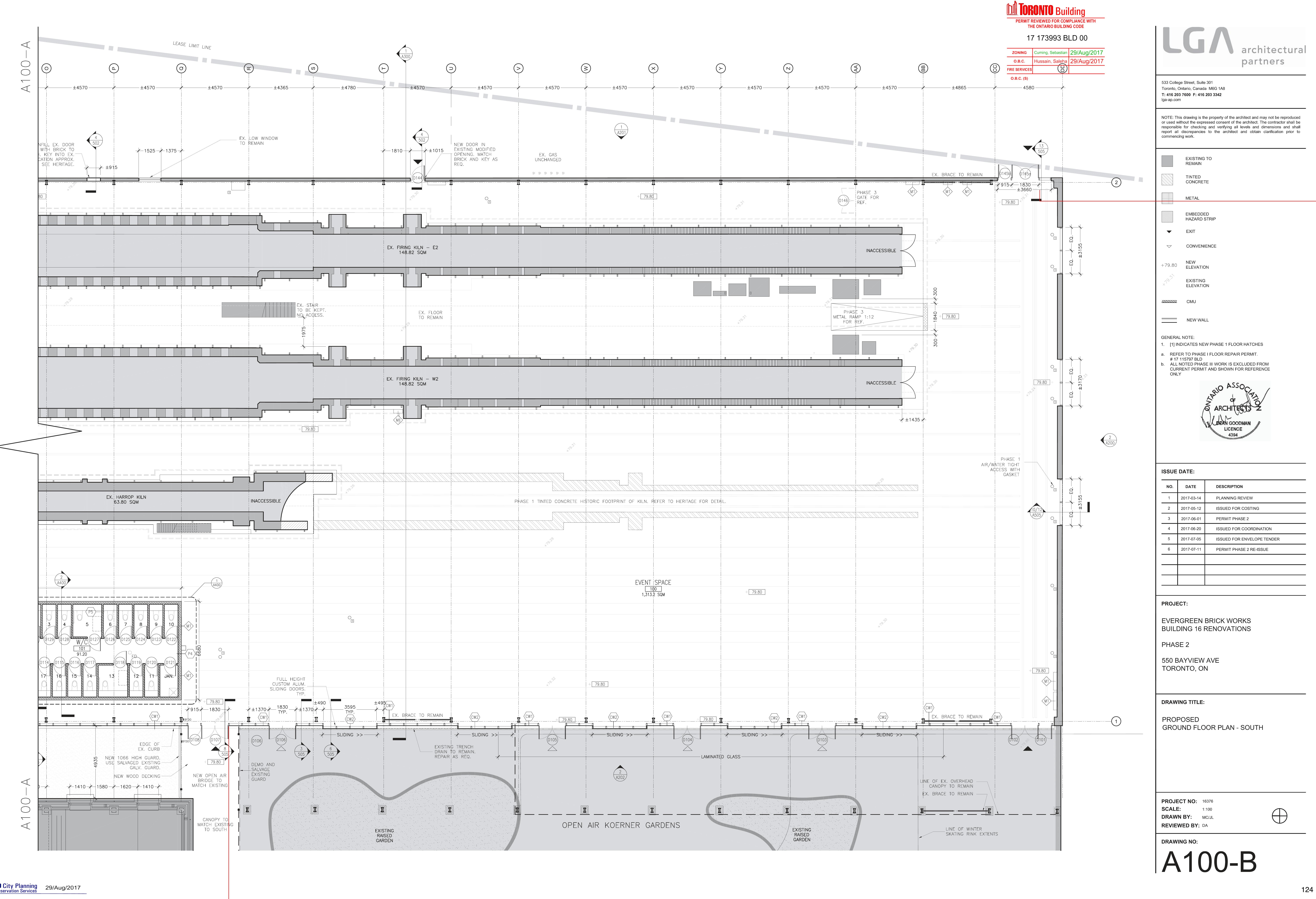




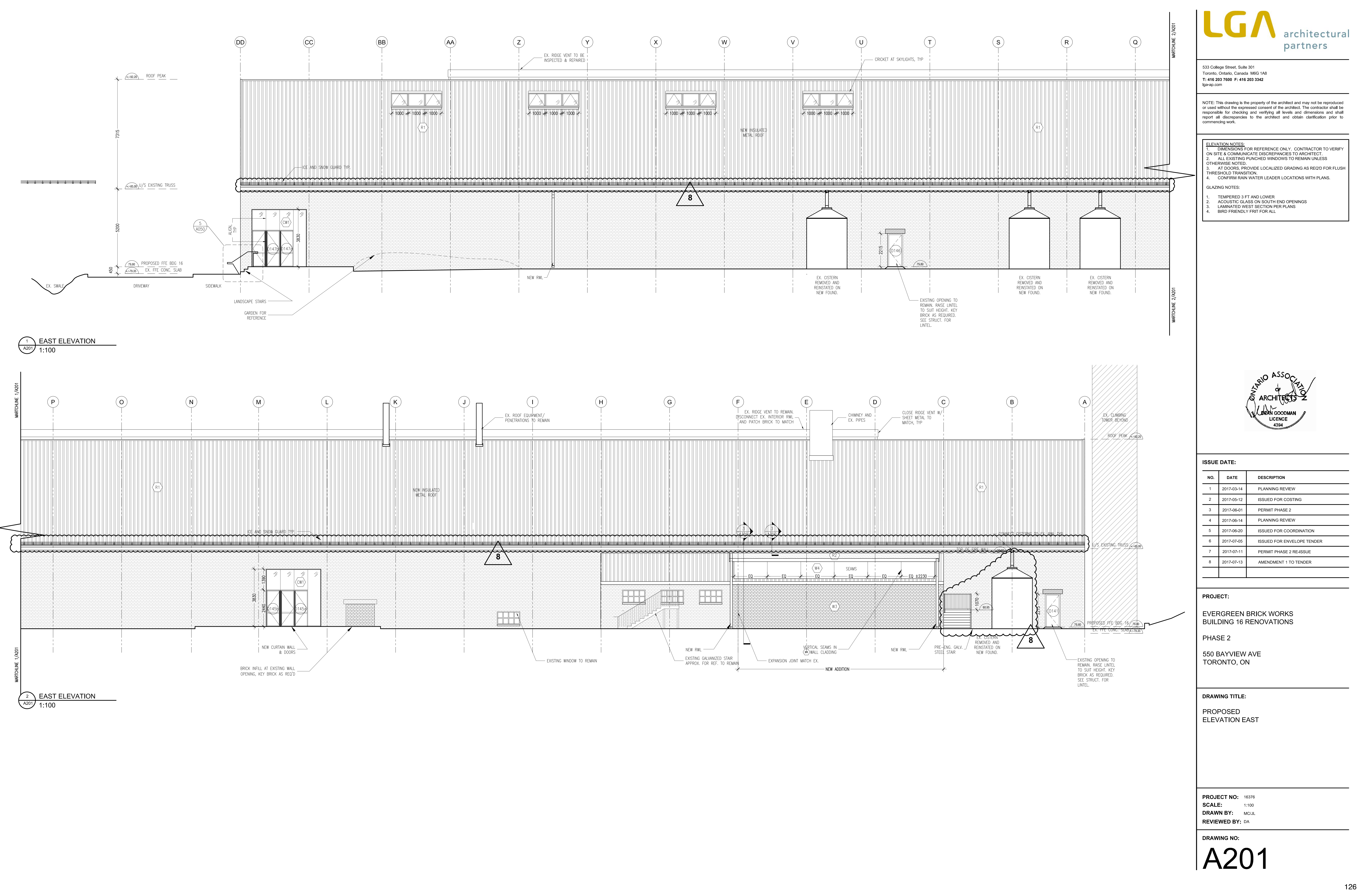




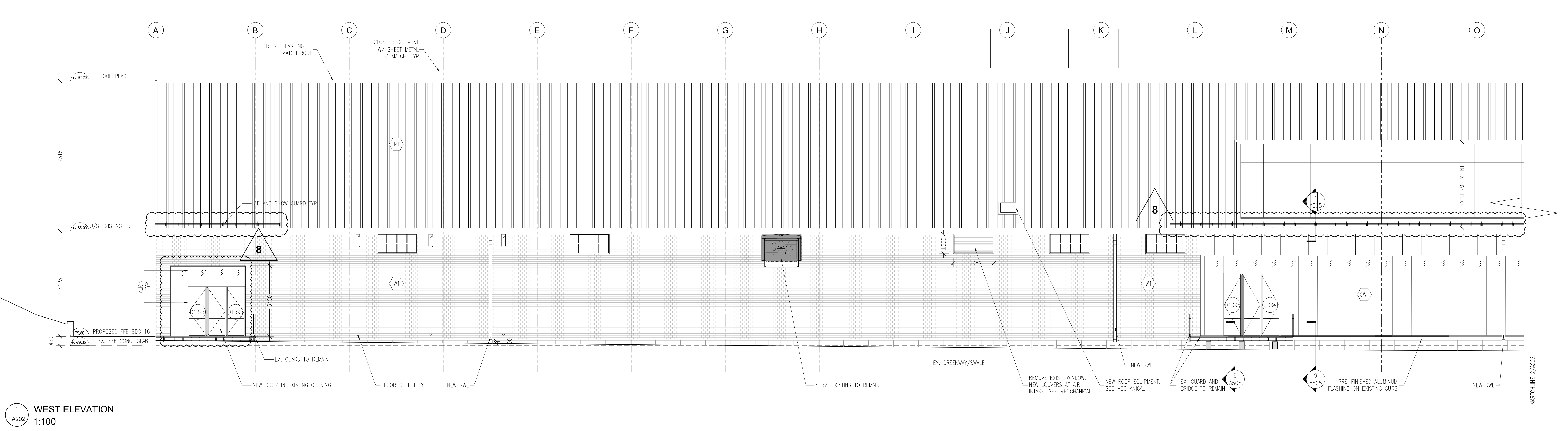

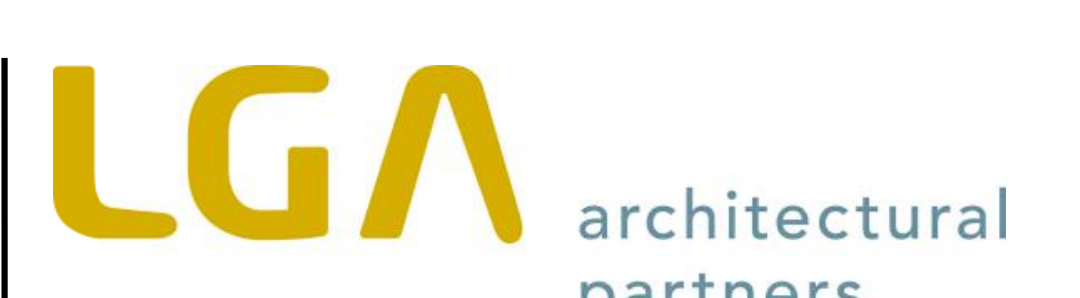

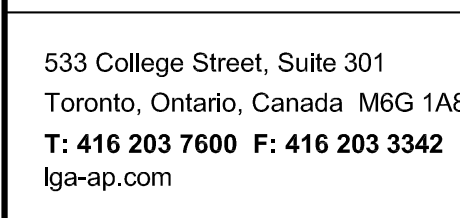

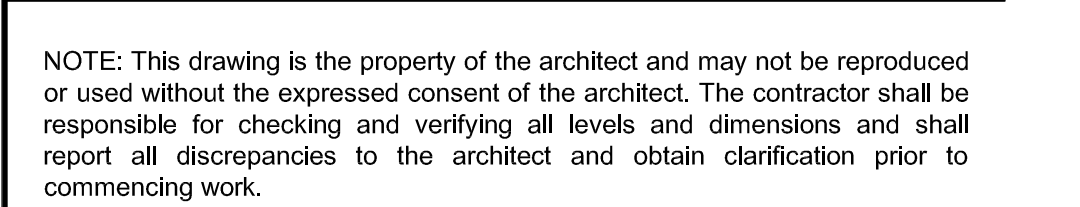

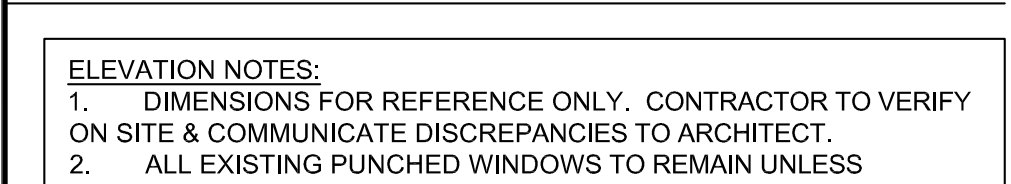

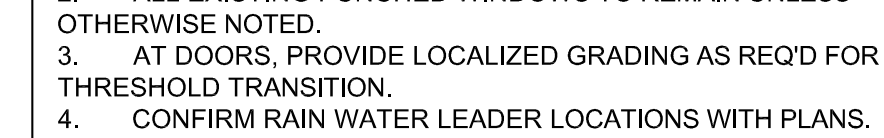

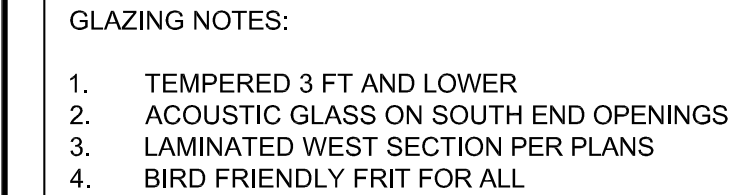

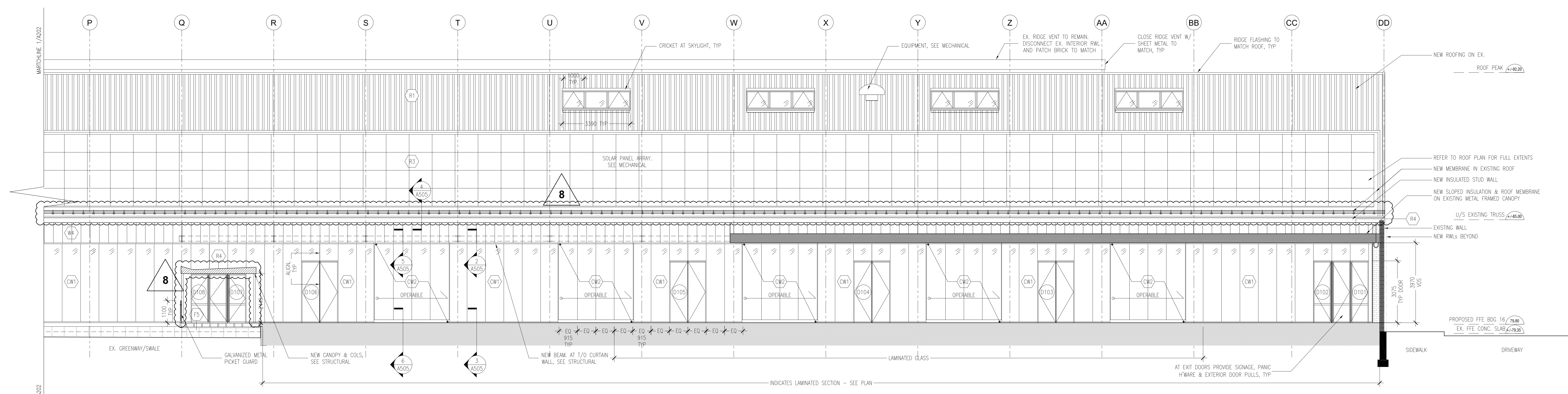

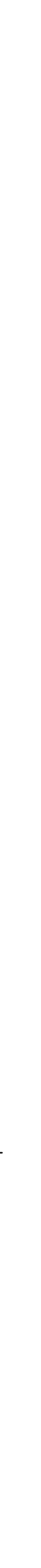

(2iag) WEST ELEVATION

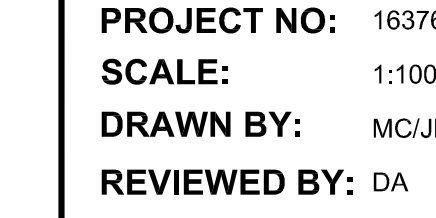

A202 


\section{EIISDON Concrete Pour Report - PDF Format: New Report (Ref. \# -)}

We build on great relationships ${ }^{\mathrm{TM}} 70256$ Evergreen Brick Works BIdg 16

Report date: 2017-Aug-23 at 12:35 Generated by: Hayley Cormick

Description:

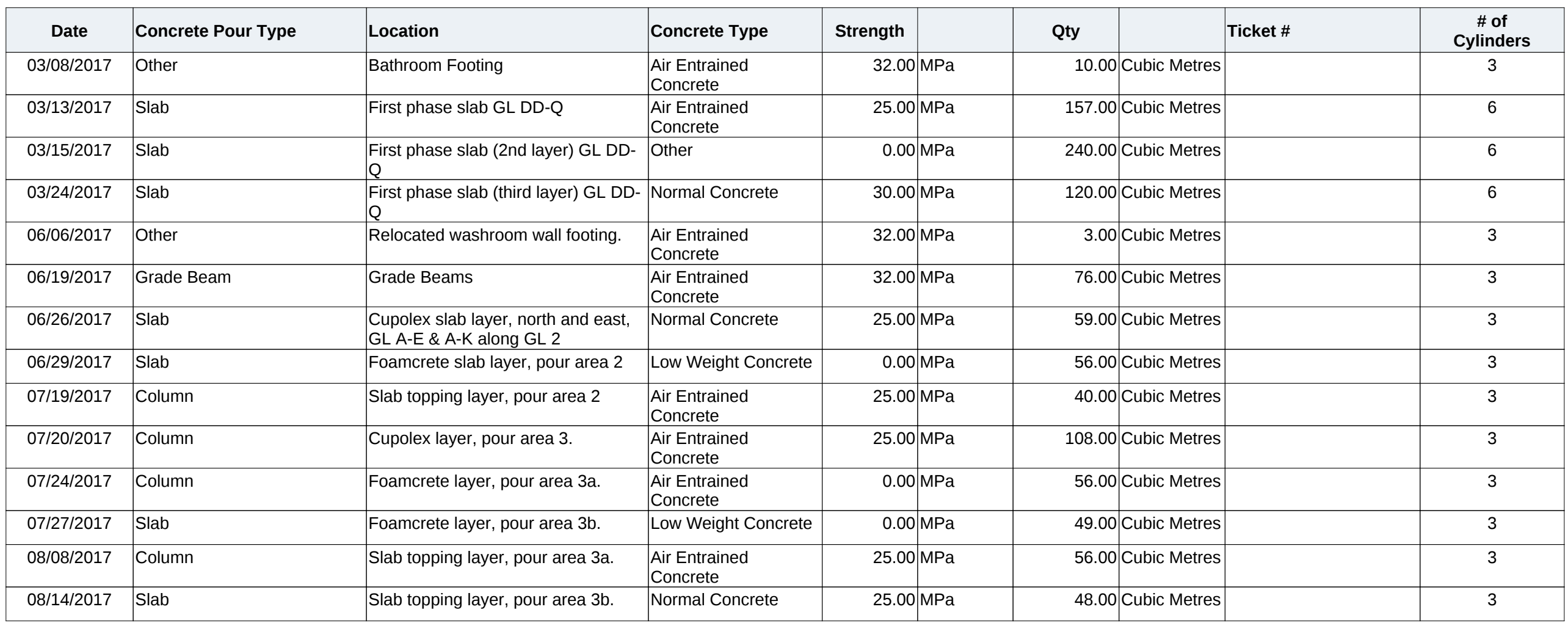

